ON THE FUNDAMENTALS OF LAW AND PUBLIC POLICY KIYOUNG KIM

\title{
THE RESEARCH INSTITUTE
}

CHOSUN UNIVERSITY 


\section{Introducing Thought}

\section{A Synopsis on the Law and Public Policy}

We subsist under the law where we claim our rights and obliged to do something enforced. What is a law? The question would be perplexing in history, and one of crucial themes with many lawyers or legal philosophers. As we know, two most important perspectives had earned a universal and historical forge in academics, to say, the natural law and legal positivism. The concept of natural law deals in its primacy for the humanity and natural order which often can be traded as something inviolable or inalienable (Maritain, J. \& William S., 2001). The concept has strands in several aspects; (i) its anchor with the civil democratic revolution around 17 and 18 centuries (ii) its supremacy with the new constitutional states (iii) less quality as a realist law from ambiguities and lack of clear definition. For example, the sanctity of property right, freedom of contract, prohibition of ex post law, self incrimination, and others may qualify for or originate from the natural law. The natural law theory provided the spirit and ground of US constitution, and generally considered to be entwined with the higher law concept, as in the case of Blackstone. The judicial review could be instituted on this philosophy or thoughts, but the Supreme Court in the Ex Parte McCardle repudiated the legal force of natural law in the real and concrete context of judicial business. However, it still is envisaged as idealistic and considered to be a prototype of justice in aspects of social intelligence. The legal positivists delve onto the basis of legal norms or their effect in the political community. In their case, they look most importantly at the state norms, hence, the political community often retracted, in concept, into a specific state or polity in order. The international community, in this purview, may lack a quality that the norms could be addressed in the coherence and system. However, a cosmopolitan concept of positivist theory, as we see in Raz, can bode prongs and intellectual consistence to explain the dynamism of international hard and soft laws. The legal positivists generally recourse the source of laws from the Grundnorm in the case of Kelsen or sovereign being as presumed by Austin. Hart's view and theoretical frame for the three phases of norms and ground for their legal effect are notable to penetrate most universally the current practice of laws in terms of the legal effect or source of law.

The concept of public policy may be related with the social justice, ethics and administration. It generally pursues a justice and desired state of public or community where the tension and conflict always exist between the ruling class and citizens (Harrington, C. B., \& Carter, L. H., 2009; Kerwin, C. M. \& Furlong, S.R., 2011). Historically, the public policy could be mightier to address the society than law where the benevolent Kings or Sovereigns liked to address both their needs and social justice. They may abrogate, more in endowment and divinity, the laws or social customs. The tension of public power and private interests could be one reason as well as offer a good dualism in understanding the rule of law concept and advent of modern democracy (2009; Federal Register Tutorial, 2014). In this dimension, the King would no longer be divine nor entitled to exercise a plenary power of state rule. Instead, the popular sovereignty in the US democracy or parliamentary one in the UK were to be established to resolve a feudal conflict within the class and society. Lighted to be in vein of influence could arise the two contexts which are a contractarian view and plutocracy desire of the founding fathers. They underlay the mood and philosophical ethos of US revolution. Hence, three concepts as a pillar in private law were sanctified in the very foundation of US constitutional state, sanctity of property right, freedom of contract and due limits for the civil liability. The governmental power should be limited to protect the life and limb of citizens 
which addressed the Hobbes' evil, “war against all the rest.” The due process concept was expressed as a fundamental principle of constitution where the human rights are inviolable and inalienable. The separation of powers principle could serve the freedom and wealth of new civil class in the continent, and bicameralism was devised for the check and balance within the federal congress. They see the role of judicial branch is important to preserve their civil interest.

\section{A Relationship between the Law and Public Policy}

From the summary, we can derive some assumptions between the law and public policy. First, a law plays to protect the private interest while the public policy pursues the social justice and mediates the competing interests, "private v. private" and "public v. private." The civil courts may address a first nature of conflict and the law of takings or regulatory laws may deal with the second aspect. Second, the public or administrative law may shape a legal plane of bureaucracies or public administration, and guarantee the rule of law ideals (2009). It plays as an enabling authority and, on the other, monitors an arbitrariness and unfairness in the bureaucratic government. In this context, the unresponsive and unfathomable bureaucracy in the Kafka's could be remedied. Third, for the welfare state in the late 19th and 20th century, a law can well be seen as one of authoritative expression of public policy to redress the evils of capitalist states. Some public laws, such as the Sherman Act classically and Lanham Act recently, may act to regulate the monopoly or oligopoly while other laws were enacted to restore the justice between the labor and employers.

A relationship involved with the two concepts could be analyzed in response to the four basic forms of law, covering the statutes, common law, constitution and regulatory laws. The statutes in the common law country are generally limited in scope and subject matters. However, the public laws share a similar extent against the civil law countries in terms of state intervention or public regulation. That comes as a good point of comparison that the common law countries have no general statute on the civil matters. The common law is specific to resolve a concrete conflict while the laws generally are abstract and designed to be implemented within the command of statutes and discretion of bureaucrats. The public agency and administration may be subject to the judicial ruling which is an apparatus or system for the rule of law and considered as an essential component of liberal democracy (2009). The Chevron rule applies to respect a discretion of agency and the court often defers to the decision of agency unless the action or decree materially contravenes the provisions or undermines the intent of law-making authority. The Constitution is a supreme law of land and every level of public authorities are expected to be bound by it. The president and congress are not an exception. They act as an independent authority to interpret and execute the provisions and spirit of constitution (Federal Register Tutorial, 2014). The constitutional review often is conferred on the judicial branch in the normal or special line of judicial hierarchy depending on the national constitutional scheme. For example, US and Japan manage a unitary structure in three or four tiers of appeal system. The constitutional review is commissioned to the normal nature of national supreme court. That can be compared with Germany, France and South Korea where we can find an independent highest court exclusively committed to the constitutional review.

The policy makers or administrators are expected to honor the Constitution and execute their constitutional responsibility faithfully in response with its command and desirability. With respect to the law and public policy, one important tendency in the recent 
age lies within the delegation of law-making authority to the Executive. The policy makers or administrators in the Executive are no longer an agency merely to implement the laws, but often delegated with the power to enact regulatory laws. This phenomenon had once been questioned to violate the constitutional provisions, which spell out three branches of government and their constitutional authority. The rule of clarity and specificity may operate to legitimate a legislative delegation.

\section{Reference}

Harrington, C. B. \& Carter, L. H. (2009). Administrative law and politics: Cases and comments (4th ed.). Washington, DC: CQ Press.

Kerwin, C. M. \& Furlong, S.R., (2011). Rulemaking: How government agencies write law and make policy (4th ed.). Washington, DC: CQ Press.

Federal Register Tutorial. Retrieved Mar. 2, 2014 from http://www.archives.gov/federal$\underline{\text { register/tutorial/online-html.html }}$

Maritain, J. \& William S. (2001). Natural Law: Reflections On Theory \& Practice, $\quad$ South Bend. IN: St. Augustines Press (2001) 


\section{The Role of Administrative Law and Rulemaking}

\section{Some Comparative and Historical Sketch}

A relationship between the administrative law and rulemaking is symbiotic indeed, to structure the public lives of citizen as well as the politicians and bureaucrats. The administrative law could be broadly defined to encompass the statutes, judge-made laws and agency rules. In this purview, the administrative law epistemologically includes the rules of various nomenclature issued by the executive authorities, such as order, decree, rules, regulations and ordinances. In a narrow sense, perhaps more friendly to the intellectuals, the administrative law is designated as the statutes of congress enacted in compliance with the constitutional and other statutory or internal requirements of the House and Senate. From this viewpoint, the two sources of law can be distinguished in terms of law-making authority, foundation of legal effect, scope and quality as a norm, and practical dynamism through the final addresses of norm or public policy (Federal Register Tutorial, 2011; Harrington, C. B. \& Carter, L. H., 2009). The administrative law springs from the congressional resolution, a political expression of public issues. In the US and general context of administrative law, the statutes in this scope had been limited and most typically had we been used to one statute, called APA, dealing with the nature of general procedural matters. The context would vary across the countries. For example, South Korea and perhaps a number of civil law countries are provided with the scope of general statutes, including the Administrative Litigation Act, Administrative Hearing Act on Cases and Controversies, Administrative Surrogate Enforcement Act. The titles of public laws dealing with the specific public issues, such as the national economy, culture, public health and environments, had been well equipped. Often this relative abundance of public statutes in these countries fuels a source of contention and disagreement in the international community about the trade liberalization. In comparison, we can note the trace of rules in history and through the contemporary government of US, which nowadays could rival in the number and scope about public intervention. This implies the substance of law and public policy now exist and is being enforced as less differently between both traditions of law despite their differences in formality. In this context, the roles of administrative law and rulemaking could be made distinct between two traditions.

The Administrative law took place more significantly in the civil law countries while the rulemaking of agencies would make practically more important impact in the US. There could exist many potentials of explicatory version about this subtlety. One reason might arise if the United States practices a federal system and its government operates within the stricture of three separated branches. Any obvious strength of rulemaking lies in its speed, efficacy with expertise and bureaucratic experience, compact procedure, non-political and subjectscale directness. The small and unitary system of government could fully exploit these advantages without any legal hurdles and encumbrances. This context may well be void under the federal system and cost a century long lessons of history for the US case. Take the example in the course materials about the Department of Interior in the earlier years of rulemaking history (Kerwin, C. M. \& Furlong, S.R., 2011). It perhaps would be confused with the role of Home ministry in the UK which has a plenary power to regulate under the delegation of parliament. Actually with respect to the federal system and dual sovereignty between the federal and state governments, the role of rulemaking could effectively be abridged to the limited scope and for its intrinsic role within the constitutional structure. This can be cast in other highlight about the foundation of federal union where the new wealthier 
class distrust with the strong government and less regulation or intervention were preferred to protect their wealth and interests (Maritain, J. \& William S., 2001). Brownlow Committee and FDR's response also showed this dilemma who described the chaos or un-system of policy makers in the New Deal era, with words "headless fourth branch" (2011, p.11). This would be a cost payable to redress any repercussion from the feudal or arbitrary rule in the earlier ages.

The concern arose and fermented to restore the social justice, while the integration and powers of national government had steadily expanded through the late of 20 centuries. We often call the 1970's era of public rulemaking as epochal. Almost all statutes enacted with the public programs delegated a rulemaking authority to the agencies (2011). The separation of powers principle once provoked a dispute concerning the legitimacy of legislative delegation, which turned to settle within the kind of important principles, for example, regularity and predictability as provided by the 1946 APA. This means that the rule of law ideals positively resolved to shake hands with the national cause toward the social justice. This speaks for the formality and system to deal with an entrenched contention between the private interests and social justice. It would be same in spirit as to the kind of benevolent capitalism, occasionally touched by the donations and contributions of Bill Gates or Warren Buffet, but could be made distinct in nature. From this, we can infer another aspect of role which is substantial and econo-political. The roles of administrative law and rulemaking underscore the legitimacy of public intervention into the private sector and for the social justice. The subject matters of these norms would encompass the production and consumers, which range the regulation of monopoly or oligopoly, minimum wage, labor hours and standard, public health, environmental protection, commercial ads, misleading and unfair practices, price valorization, and so on.

\section{Their Roles: Rule of Law and Modern Administrative State}

The role of Administrative law can be found in its paternal play for the rulemaking as we consider one APA provision, "[r]ule means the whole or part of an agency statement of general or particular applicability and future effect designed to implement, interpret, or prescribe law or policy" (2011). It grounds the plane that the agencies execute their powers and duties. As the Constitution binds, the president has the duty to faithfully execute the laws. A scope of constitutional powers other than this was prescribed in the Constitution. Nonetheless, the execution of laws clause would be one of traditional intrinsic historically and within the modern practice of constitutional state. Because of a strict hold with the separation of powers principle, the kind of emergency power was not incorporated within the US constitution although the presidency of US often had been attributed as a modern replacement of feudal King. This is in contrast with other modern presidential system of democracies, such as France and South Korea in 1970's and 1980’s. Even the Korean constitution enforced since 1987 spells out some of emergency power for the president to write the statutory laws as equal in status with the congressional act. This system have been absent in any expressive language and were deferred to the constitutional practice as we see in the Youngstown case involving the 1950 Korean wartime. In this light, we consider the execution of laws clause is fairly important in understanding the executive power within the US constitution. Then how could we define the laws enshrined in this provision? We may take an expansive view which includes the federal constitution, statutes, common laws and administrative rules. It does not outright reject an assumption that the president and agencies can make the rules necessary to carry their office. Consider the federal supremacy clause. 
This assumption would attain if there are no definite statement in the Constitution about the hierarchy of norms among the forms of federal law. The controversies questioning the constitutionality of judicial review, though founded in Marbury v. Madison, arose in the same structure of logic and metaphor between the administrative statutes and executive rules.

However, we may infer from our intuition and natural laws that the Constitution is supreme over other forms of federal law. Since the laws are the product of institution constitutionally created, they could not negate the mandate of constitution as a matter of nature. This logic can be applied to the relations between the APA and executive rules. The Congress was expressly conferred the power to legislate while the brother branch was described an authority for the execution of laws. They are co-equal and brothers from one father, namely the Constitution. I take a view that an express intent of constitutional drafters should prevail that no independent or contradictory rulemaking are to be legitimately disabled. This means that the administrative acts or illustratively the APA will govern and enable a rulemaking. In summary, APA will command source of laws (agency), subject matter of rules (law and policy), scope of influence: implement, interpret, prescribe (2011).

The roles of rulemaking in public policy making are enormous in the contemporary times. A historical survey informs the trend of rulemaking in its inception through the end of last century. As we see at the first page of Kerwin's, the society recently stirred about an AIG issue which implicates the public power over the civil arena (2011). A rulemaking defines a scope of specific issues which could make a profound effect on the lives of US citizen. They prescribe any more influentially the rights, benefits and services to be entitled to the American citizen. As C. Diver commented, it would be a skin of living policy if we can add for the statute, “cloak of skin" (2011). I am, however, reluctant to say this, if we are more concerned about such specific provision of rules than an abstract generalization of statutes. The bureaucrats certainly are an important player to address the social justice which should not be momentous. It should be living to adapt with the changing circumstances, but would be required of the extent of consistency, formality and generizability. The rules decreed would be an expression of living policy under the cloak. Its role can be said to realize the distributive justice as Plato enlightened, which is specific and in accord with the social justice or equity.

\section{Reference}

Harrington, C. B. \& Carter, L. H. (2009). Administrative law and politics: Cases and comments (4th ed.). Washington, DC: CQ Press.

Kerwin, C. M. \& Furlong, S.R., (2011). Rulemaking: How government agencies write law and make policy (4th ed.). Washington, DC: CQ Press.

Federal Register Tutorial. Retrieved Mar. 2, 2014 from http://www.archives.gov/federalregister/tutorial/online-html.html

Maritain, J. \& William S. (2001). Natural Law: Reflections On Theory \& Practice,

South Bend. IN: St. Augustine Press (2001) 


\section{The Tripartite System of Government}

\section{The Distribution of Governmental Powers}

The United States is an original state which embodied the constitutional scheme of government. The trace may be alleged in the earlier countries of Germany where the fragments of constitutional nature of rule were practiced. However, the prevailing views support that the US guides a modern form of constitutional democracy. That is true since the US context heralded the demise of despotism or abusive monarchy, systemic institution of democratic government, incorporation of bill of rights, unique form of laws titled in this great name and with different steps to repeal or amend (Great Neck Publishing, 2009; Jefferson, T. Washington, G. \& Second Continental Congress, 2010). It is harder in aspects than the statutes, common laws, and decrees or orders of executive. If a simple majority rule in the Congress previously should say anything about the rule of nation or state, the constitution is inviolable without some weighted process of amendment. The US constitution could be considered as epochal to adopt the presidential system of government and orthodox in terms of the separation of powers principle and tripartite government. The ideals enshrined in this principle were to ensure the liberty of people and safeguard the virtue of limited government (Bernstein, D. E., 2003). The concept of limited government offers a paradigm to protect the wealthier class and should be pivotal for realizing the plutocracy in this new Republic. Bicameralism and dual sovereignty between the federal and state government are another point of deliberation exercised by the founding fathers. All the way through this founding philosophy, their emphasis was given to prevent against an absolute power or tyranny. Hence, they intend to provide a check and balance mechanism among the three branches of government. Therefore, we could arrive that the separation of powers principle had been a focus to grant the constitutional powers of each branch. This leads to the basic that the governmental branches have to be clearly conferred with the power to create and execute the public policy. For example, the power to tax, coin, and raise the army was provided as the responsibility of Congress. The power to approve the treaties with foreign nations exclusively would be vested within the Senate which would be same as in the unreviewable approval of an appointment of major public offices by the President. The suit against the ambassadors or foreign nations and between the different states falls exclusively within the federal judiciary. We could identify a scope of explicit language which prescribes clearly the can-do and cannot-do within the document itself.

The twilight zone certainly exists to blur if one or other branch can or cannot create or implement the public policy (Bailey, M. A. \& Maltzman, F., 2008; Funk, W. F., 1997; Hamilton, L., 2006). As a matter of nature, the constitutional document is basic and principled which generally deals with the elements and fundaments in organizing the national government. It provides the structure of government which is pivotal and with their organization, roles and key constitutional responsibilities. For example, the Senator must reach the age over thirties if eligible to be elected. The Executive is empowered to execute the laws, and assumes the role as a chief of commander. The power to declare war is vested within the Congress. If not surfaced leading to express dealings, we would face a tough work of constitutional interpretation. For example, we have to complement the scope of appointment power whether the Postmaster is an office to require the approval of Senate. Lower ranks of executive officer fall outside the constitutional ambit so that no approval of Senate has to be prerequisite. Nonetheless the scope of lower ranks would not be certain which brings a need to examine. Two other notorious examples can be presented. The 
legislative court is one and the judicial review of federal statute would be the other. The Constitution provides a national judiciary in the Article III in terms of qualification and requirements. The Article III court judges, for example, would enjoy a lifetime tenure, and the judicial power was vested in terms of case or controversy requirements. Other elements had also been spelled out to cover the due context of constitutional command. This militates against the creation of other tribunals which could deal with the need of adjudication. As we see, the modern administrative state requires exercising an adjudicatory power in response with the complication and diversification of public rights or interests. In some cases, they have to adjudicate whether a person should be deported or confined within the mental hospital (Harrington, C. B. \& Carter, L. H., 2009). This role is now often undertaken by the legislative court which is based on the Article I of legislature. In this case, we consider it does not encroach upon the judicial power since it falls within the sphere of congressional power. We term this nature of court or tribunal as Article I Court to distinguish from the Article III Court. The other example involves the court precedent, entitled Marbury v. Madison, which enabled the legitimacy of judicial review. The Constitution provides no express provision to ground the judicial review of federal statute. The creation of this judicial theory is still debated involving its anti-majoritarian nature.

Therefore, we may summarize (i) expressive provisions and terms of Constitution are the source of creating or implementing a public policy, (ii) vacuum, vagueness, and ambiguities are unavoidable because of the nature of Constitution which makes it amenable to devise and craft to fill for creating or implementing a public policy, (iii) in primacy, such gap-filling work is to never contradict an express mandate of Constitution, (iv) the work also needs to be reasonable and in comport with the design and spirit of Constitution.

\section{Whether the Encroachments of One Branch over Another Would be Necessary?}

The separation of powers principle generally provides a goodness for the paradigm of limited government and functions as a shield of liberty interest. The founding fathers envisaged a limited government which also works to address their ideal of plutocracy in the new Republic. They laid a foundation of tripartite scheme of national government in which the legislative, executive and judiciary are expected to perform their constitutional role and function. The Constitution prescribed the selection of members within each branch and their constitutional powers as mutually separated and independent. The bicameralism was adopted between the Senate and House to preserve a prudence and against the radical action possibly as arbitrary.

As argued by Rosenbaum, the typology of modern public administration could be viewed in three major perspectives, to say, managerial, political, and legal (Rosenbloom, D. H., 1983). As explained, the Constitution generally is limited, in its dealings and prescriptions, to the key issues and structures of national government. This leads to the vacuum of provisions and ambiguities that the branches, in some sphere, could not be determined about the constitutionally delegated power. We can illustrate one typical area which would be historically grey without any express constitutional language. The war making power of Congress and the role as a Commander in Chief expected about the presidency could overlap or compete precisely because no definite statement was ordained in the document. The nature of wartime nation involving an emergency and speedier responsiveness may well require the President to leapfrog the congressional approval. The legislative veto is another example if the legislature prefers to dispose their responsibilities in convenience and expediency from the burdensome work of prescriptive power. One way to respond with the increasing need of 
public regulation could be a delegation of rulemaking power to the agencies while the legislative veto is some opposite way to preserve their power to control the agencies and their decision (Kerwin, C. M. \& Furlong, S.R., 2011). Chadha case directly concerns that issue, and the Court invalidated the act authorizing the Congress the power to review a deportation decision made by agencies. The rationale is that the source of congressional authority is confined to the Article I of Constitution, hence, only could be legislative in nature which requires a constitutional process about the presentation and presidential veto. The legislative veto actually should have been executive or judicial in function since it disposes concretely the interest of individual as we turn on the nature of executive and judiciary. The legislative veto is neither prescriptive nor abstract or general which should not be legislative, but the Court would see it in that way because of no constitutional ground about other two. Then the logic is straightforward that the Congress is required to respect the constitutional protocol about a legislation. The case showed a distinct aspect of the separation of powers principle where one branch is forbidden from encroaching upon other branches. In terms of the public good and rule of law ideal, we can derive some elements in the constitutional practice of encroachments. First, the ways and level of constitutional prescription may not perfectly cover all the essentials about the Union and federal government. This offers a major reason that one branch may encroach upon other branches in the circumstances where the public cause is emergent or ambiguities are gross disproportionately with the needs of action or extent of public cause. Second, the mixed nature of document entailing the political, on one hand, and legal, on the other, lends a space of encroachments. The historical wake or tendency can be traced as embedded on two viewpoints between the strong and weak presidency (Separation of Powers, 2014). In this case, the encroachments may be argued and political aspect could be gauged in consideration of the value of constitutional democracy within the national politics and rule of law ideals. The political doctrine developed by the judicial authority would be presumed on these possibilities and for the consistence of constitutional rule.

\section{The Judiciary and Public Agencies in System}

In terms of law and public policy, I consider that the judiciary and public agencies function in dual context; (i) independence in office and responsibilities (ii) check and balance. They are independent since the president is elected on a different basis of election. The executive offices are not filled by the judicial branch even if the inauguration of presidency is carried symbolically in the face of Chief Justice. The president can exercise an appointment power about the constitutional status of higher rank officers. The Senate can constitutionally intervene with the approval power, which could be understood from the check and balance scheme. For other ranks of executive officers can be staffed solely within the discretion of President. They are also independent in responsibilities partly because the executive power is explicitly conferred in provisions of constitution, and also because it could be a residue, in one viewpoint, from a more defined scope of two other powers. It generally would encompass the scope of powers in realizing the specific justice vastly in ways of execution of laws. This means that the public agencies do not assume the adjudicatory role, which is quite contrary in this modern administrative state. As we see, we can group three basic types of federal administrative agencies (i) independent regulatory commissions; (2) agencies housed within a cabinet level department; and (3) agencies outside the formal structure of a cabinet department (Harrington, C. B. \& Carter, L. H., 2009). From this, we can identify a scope of independent agencies or regulatory commissions to review and be adjudicative. They stand 
on an independent footing from the line of bureaucracy and make a resolution on a quasijudicial process and in the adversary argument. The legislative court on Article I often would fall within this class. The justices of Supreme Court are nominated by the President, but with the approval of Senate. This process of appointment serves a dual role in terms of separation of powers principle. In this way, the judiciary can be checked by both organs and independence can increase since two branches collaborate, as not staffed solely by President. The constitutional power of judicial branch was set forth principally in the article III, and the legislature complements with the constitutional mandate by enacting an organizing and enabling statutes. The Judiciary Act in 1789 provides a basic system of national courts which later fueled the controversy involving a possibility of judicial review and leading to the unconstitutionality of the Act. The judicial review of legislation or administrative decrees and rules can be received as an avenue to realize the check and balance for the ideals of limited government and safeguard of civil liberties. There are aspects of constitutional institution among the three branches ideated to facilitate the intent of founding fathers, who gravitated on this two folds of consideration (Separation of Powers, 2014).

\section{The Judiciary, Law and Public Policies}

In history and current practices, the judiciary has been an important peer in creating and executing the law and public policy, who checks, defers, and supports the exercise of power by the administrative branches.

First, they checked or controlled a creation and execution of law and public policy. The arbitrary power of agencies could be invalidated and ordered null as a matter of law, which is concerned of the rule of law ideals. It may be struck down on its face and in the context of application to a specific case if it involves a rulemaking in any general context. If the administrative court is engaged in a disposition or decision specifically addressed to a damaged party, the application of law or rules could be denied. The due process concept of law requires the judiciary to give a fair reason published to the public, which informs the citizen and agencies of what is the law. The basis of judicial control could be grounded on the Constitution, statutes, and common laws. Given the federal system of union, the federal constitution is a principal source of contention between the disputed parties. This is particularly so since the dual sovereignty between the federal and state government had long been an entrenched issue in the Constitution and administrative laws. The constitutional rule influenced, in terms of legal acculturation, the unitary system of government, who would be a protégé of American ways of constitutional state. This leads to the prosperity of constitutional culture where European thinkers generally consider the rule of law as one ingredient for the modern democracy. They may also practice a separate authority, say, dual or multiple supreme courts to specialize. The German and Korean constitutional court would be some examples. In this system of interaction, the public agencies often are well-versed not only with the constitution or statutes, but also with the case laws concerning the law and public policy. The article from Rosenbloom argues on the three dimension of public policy in strands and characteristics, i.e., managerial, political, and legal, which denotes the importance of legal aspect within the public policy (Rosenbloom, D. H., 1983). The public policy is not to be arbitrary nor usurp the political delegation where the spirit of trusteeship and concept of social contract could entertain any primacy. They respect the concept of inviolable or inalienable human rights and are entrusted to rule in foundations of the sanctity of property rights, freedom of contract and due limitation on civil liability. It is considered that they are 
accountable to the elected officials, which implies the political dimension of public policy. This indirectly ensures the rule of law ideals. Most importantly, however, judicial review of administrative action comes as the central niche to control the agencies and as directly, which signifies the importance of judicial branch in creating and executing the law and public policy.

Second, the judiciary, in the fair extent of ambit, tends to defer to the administrative decision or policy-making. The court practices in this focus could be explored in several perspectives. The statistical analysis based on empirical data guides that the judiciary often would be highly disposed with the laws rather than public policy. The research outcome from Bailey \& Maltzman elicited that legal factors play an important role in Supreme Court decision making (Bailey, M. A. \& Maltzman, F., 2008). It also supports the tendency that the effect of legal factors varies across justices. This research finding corroborates with the views of judicial scholars, which likes to disentangle the effects of law and policy preferences (2008). It also helps to strip an illusory impression that the Supreme Court would be a small legislature of nine justices. This implies that the judicial branch is important to provide the basis of laws in consistency, predictability and legal stability. We can say this since the political branches respect the will of constituents and highly malleable with the changing circumstances. Still, however, do the creation and execution of law and public policy suffer from the potential conflict between the demand of public administration and legal requirements provided by the judicial branch. That would be an area of subtlety that the policy makers or administration could apply their expertise and professionalism (Kerwin, C. M. \& Furlong, S.R., 2011). The elements of judiciary, in this role and responsibilities, could recourse in terms of political question doctrine, adherence to precedent, judicial restraint and a strict interpretation or plain language rule (Bailey, M. A. \& Maltzman, F., 2008). For example, the doctrine of political question would allow a leeway outside the judicial control in creating or executing some limited scope of public policy, such as war authorities, war command, treaty making and foreign policies. The standard of this doctrine had been welldefined in judicial terms, however. Adherence to the precedents fosters the stable creation and execution of public policies. Judicial restraints were developed to connote the lack of immediate political representation within the judiciary. This theory alongside the doctrine of political question could be illustrated in terms of judicial deference. Nonetheless, the deference in the administrative law can be ordained in the Chevron rule, which narrowed a judicial intervention in principled ways. Therefore, I consider that the creation and execution of public policies generally survive provided if: (i) they do not infringe with the express language of Constitution and statutes (ii) the discretion of policy makers is neither arbitrary nor grossly failed against the purpose of constitution and statutes.

Third, the judicial branches could support the creation and execution of law and public policies since they invalidate and sustain them. The multilayer checking mechanism from the administrative action through the judicial review enables a kind of juggernaut to define the public lives of American citizen. The Federal Register, for example, provides a system of reference in combination with the Constitution and administrative law. This scholastic complexion provides any compounded intricacies increasing the credibility of public authorities. The public agencies can play creatively and judiciously in response with their responsibilities. The case laws could guide them and support the appeal of specific policies for the constituents or policy addresses.

\section{Reference}


Harrington, C. B. \& Carter, L. H. (2009). Administrative law and politics: Cases and comments (4th ed.). Washington, DC: CQ Press.

Jefferson, T. Wahsington, G. \& Second Continental Congress (2010). The Constitution of the United States of America, the Bill of Rights \& All Amendments, the Declaration of Independence, the Articles of Confederation. Washington D.C. :Megalodon Entertainment LLC.

Kerwin, C. M. \& Furlong, S.R., (2011). Rulemaking: How government agencies write law and make policy (4th ed.). Washington, DC: CQ Press.

Bailey, M. A. \& Maltzman, F. (2008). Does legal doctrine matter? Unpacking law and policy preferences on the U.S. Supreme Court. American Political Science Review, 102(3), 369-384.

Rosenbloom, D. H. (1983). Public administrative theory and the separation of powers. Public Administration Review, 43(3), 219-227.

Separation of Powers (2014). Retrieved Mar. 10, 2014 from http://law2.umkc.edu/faculty/projects/ftrials/conlaw/separationofpowers.htm 


\section{The Role of Administrative Agencies}

\section{Some Institutional Basics}

The administrative agencies assume an important role in the formation and execution of laws and public policy. According to Harrington, there are three types of agencies (i) independent tribunal or commission (ii) agencies within the level of cabinet (iii) agencies outside the cabinet level. (Harrington, C.B., \& Carter, L.H., 2009). The APA guides three factors to be respected in the rulemaking and implementation of public policy, i.e., information, participation and accountability. The role of administrative agencies will be defined from the sources of law to which they generally are bound in forming and executing the law and public policy. The administrative agencies are empowered with the executive power in the line authority and under the command of President. Their offices, in some limited ranks and on independent ground, will be prescribed as a matter of constitutional law, such as Ambassador or Supreme Court Justices and legislative court in the Art. 1. Other offices will base their authority and responsibilities on the statute or executive order. Therefore, our first look at the role of public agencies should be directed to the provisions of relevant norm, which prescribes the basis of empowerment. There could we find a distinct status, for example, between the Postmaster and member of Federal Trade Commission. In Humphrey's Executor v. United States, the Supreme Court decided on the presidential power to remove certain executive officials (Mashaw, J.L., Merrill, R.A., Shane, P.M., 2009; Humphrey's Executor v United States). Humphrey was a member of FTC, and viewed to neglect or oppose the new deal policies by President Roosevelt. He dismissed Humphrey, but solely on the basis of political differences and without the consent of Congress. The Federal Trade Commission Act stipulated a cause for removal as limited with "inefficiency, neglect of duty, or malfeasance in office." The Supreme Court distinguished from the Myers in view that FTC would be a "quasi-legislative," "quasi-judicial" administrative body created by Congress (2009; Humphrey’s Executor v United States). This requires the President has to be bound by the causes explicitly stipulated by the statute. The Postmaster, on the other hand, would be purely executive in its structure, power and responsibilities which permits the President to dismiss any time and on any ground. The case could give an implication that the role of public agencies in some dimension would be elevated to the point of constitutional value such as organic independence and semi-nature of the Separation of Powers. The mandate and requirements in exercising their power to rule and implement are not to be usurped. Otherwise, it may offer the ground to be annulled as a matter of judicial control. Of course, there often exist a scope of interpretive possibilities since the constitution, statutes and executive orders are abstract which often leave a leeway required of interpretive work and for finding an exact mandate. Their authority and role are, therefore, properly inferred from the conferring statute itself, higher norms and intent of the sovereign people (Harrington, C.B., \& Carter, L.H., 2009).

According to M.K, Cornelius, the rules created by the administrative agencies are classed in view of two concerns (i) policy area and agency of origin (ii) dimensions performed by the rules (Kerwin, C. M., Furlong, S.R., 2011). For example, CFR allows us a vast scope of policy areas in fifty distinct categories called titles and chapters in order to correspond with respective public programs, policies, or agencies. More classic method classifying rules was suggested in the definition cited earlier from the administrative procedure act of 1946. It embodied two concepts legislative or substantive and interpretive rules (2011). The legislative rules permit the agencies to play a serious role to prescribe law 
and public policy which can amount to new law. In preserve of the interpretive rules, the role of agencies is to clarify the meaning and implications of existing law and public policy so that the public can conform their behavior to the standards and guidelines. In this way, they do not impose new obligations, but the public could rest from new or unanticipated circumstances as well as the vagueness or ambiguities of law and administrative rules.

In contemplation of the role of rules and public agencies, we are compelled to consider what and whom rules affect (2011). They are vastly related with the private behavior, and the government could be a norm receiver in some aspect. In other strands, we need to hold a focus on the difference in scope and importance. While the Federal Register publishes the rules as brief and in terms of narrow activities, there are some cases of lengthy rues as we see the federal aviation administration rules (2011). The long pages of rule do not necessarily mean it is important. In view of the role of public agencies, it needs to be noted that the change of APA made them to be freer from the strict procedural requirements. Hence, the speed and flexibility was bought in strategic ways to increase their role. On the other hand, the administrative agencies could emancipate themselves on the ground of exceptions, exemptions and evasions. They would signify the distinct role of administrative agencies about discretion, expertise, and orthodoxy or aura of professionalism from a mechanic concept of functionaries.

\section{Information, Participation, and Accountability}

The administrative agencies carry their responsibilities and form or execute the law and public policy based on the information. The modern paradigm of administrative state is expected to play a huge role for the social welfare and justice. The characteristics of their role could be identified in two folds, to say, provisional and adjudicative. This facet would be made distinct from the classic concept of limited government. In this notion, the public agencies principally would focus on their efforts on the limited role of policing or national defense. They principally sought to regulate to protect the liberty and property rights of people, which, even in the modern times, still are vast in view of the governmental responsibilities and commitment. The regulatory role of modern welfare state has expanded in role and public intervention which raises a difficult area of social or economic justice, for example, fair competition and regulation of monopolistic power or oligarchy, anti-dumping or countervailing duties, compulsory licensing for public reason, and so. Most importantly the public agencies in this administrative state are provisional and adjudicative of the complicated social or economic issues and disputes. The independent agencies or tribunal would be typical and most representative in this concern that their role often is considered quasi-judicial (Stulz, K. M., Shumack, K. A., P. Fulton-Calkins, 2012). This also is related with the important principle, i.e, the exhaustion of remedies for the judicial review. It has implications that the administrative matter entails a distinct preserve about the autonomy and professional expertise. Therefore, it would be wise to allow their selfdom for a mutually satisfactory resolution between the aggrieved parties and executive branch. One other rule, so-called Chevron, would be notorious in terms of a deference to and respect of administrative autonomy or primacy. The dimension in this kind could arise from the theories and realities which, I suppose, mainly reflect on the resources, capabilities, and professional expertise of Executive or administrative agencies (Mashaw, J.L., Merrill, R.A., Shane, P.M., 2009; Kolber, M., 2009). I consider that these elements could stem from the fact that the public agencies act based on the information and scientific knowledge. This could make the executive afforded and affluent in pursuit of their policy goals and functions to prevent any 
arbitrary rulemaking or unpredictable execution of law and public policy. In this context, the bureaucrats and public officers are required to be competent equipped with the adequate knowledge and professional experience. In the recruitment process, the educational background and expertise as well as experiences should be carefully evaluated, for instance. Another institution or practice would be a seniority system for the practical workforce within the administration, which would be in contrast with the spoils system for major political posts. The higher levels of seniority system could be traced to the Britain, Japan and Korea where an intricate compensation scheme are well defined and statutory shield to protect their job status are afforded as a matter of law. Of course, the protection would be relatively lesser against the judicial officers in a scope of countries since the latter would be privileged as a matter of constitution and in the scheme of judicial independence. With an adequate system, the public agencies need to be bred in terms of the informed or science-minded public agencies and for their expertise. The role of public agencies is important to safeguard the paradigm of participation and accountability which are essential concerning the democratic value and principle (Harrington, C.B., \& Carter, L.H., 2009; Stulz, K. M., Shumack, K. A., P. Fulton-Calkins, 2012). The public agencies are servant to uphold the will and desirabilities of sovereign people. They are responsible for the head of executive branch who is elected in the independent election. The president and public agencies under his command and control are expected to execute their duties with respect to those two paradigms as set forth in the APA. The delegation doctrine also had created the circumstances where the public agencies are compelled to deliberate how to shape the rule and establish a guideline to execute the public policy. This role would be quasi-legislative increasing a need to collect the views and opinions of constituents. The protocol for participation may be explicit within the statutes or pertinent laws while the public agencies may exercise a discretion for any due and reasonable process to interact with the public. The public agencies are required to be accountable for their policy making and execution of it. The accountability could be viewed in three of aspect; internal, political and judicial. The public agencies are responsible to the unit or organs in the line authority. The directors of bureau or assistance Secretary of DOC have to respect the command and order from the Secretary, and finally summated at the control of President. They are accountable to the constituents, but in indirect ways unlike the Congress. The public opinion would threaten a reelection possibility of President if they view the administration any bad or disrepute. The judicial accountability is fairly systematic to adjudicate the disputes between the parties and public agencies.

\section{The Department of Justice in the Republic of Korea}

As the KAPA (Administrative Procedure Act of Korea) prescribes the same extent of subject matters and attitudes, I could be allowed to deal with the DOJ, its policy to protect the victims of crime and the rule responsive to that policy. The department of justice in Korea is one of cabinet- level public agencies which assume the responsibilities of criminal policy and national legal system, criminal investigation and prosecution, as well as execution of the convicted criminals. They generally supervise the national police in the context of criminal investigation, and the controversies for the monopoly of investigatory and prosecutory power had been intense and contended by the national police. The department supports a legal system and is responsible to manage the national prisons. They act within the organic statute, named the Act on the Prosecution Office, and the criminal procedure required that they are one unit in a uniform representation and effect of their legal act or disposition. Their role has long had a focus on the traditional notion that the suspect or criminals should be afforded 
with a maximum extent of constitutional shield. Hence the adherence with the law "beyond reasonable doubt" and maxim "One innocent man should not be punished even if we fail to incriminate one hundred guilty minds." The strict elements of criminal culpability had been respected as a public good. This classic value in the criminal system became increasingly challenged in the Korean society (A Public Bulletin: The New Rules of DOJ, 2005). A scientific knowledge and adequate information guide the agencies to reshape a paradigm for the social justice, which the criminal victims would deserve. The victims of sexual crime and their families, for example, would mentally suffer while the perpetrators often may set free from a short imprisonment. This context exacerbated the public sensibilities of justice in Korea, and the government explored the policy response to serve a due protection of the victims and their families.

\section{A Protection of Criminal Victims}

The rule created by the DOJ was intended to supplement the Act on the Protection of Criminal Victims, which was enacted Dec. 23, 2005 by the National Assembly (2005). The Act came into force as of date, Mar. 24, 2006. The Rule provides, in response with the delegation of Act, the specifics, organs and standards which support the new policy. The Rule requires, in the mandate from Art. 8 of Act, to tender the adequate information of criminal proceedings. The scope of must-tender information was classed to include (i) investigationrelated information, say, progress of criminal investigation and outcome of final disposition) (ii) the time schedule and progress of proceedings, for instance, the date of hearing, the court on charge, the sentence, the date of sentence, the status of case about the finality and appeals (iii) execution or other status of penalty (parole or surveillance, completion of the sentence term, transfer, death, exiles) (iv) the status of parole or surveillance conditions and monitoring (the jurisdiction of parole or surveillance office and etc.) (2005). The Rule also supplements with the Art. 2, which sets forth the organizing details for the policy. An independent commission is to be created and operated on the requirements of Rule. The Secretary of DOJ will be a chairperson of commission. The deputy secretaries from pertinent departments and Supreme Court Administration, and second ranks of KPO and national police will be staffed as a commissioner. The commission could be provided with the civilian experts less than ten in number which would promote any more nature of professional decisions. The term will be two years, and the Rule shows the context of APA themes and standards, such as information, participation and accountability. The Rule serves the policy to protect the criminal victims for example, if they are mentally inflicted and, in some cases, fear of further crimes or revenge from the criminals. The information about a parole status of finished criminals may reduce their mental stress or post-crime trauma. As the policy involves a difficult psychic issue, the participation of civilian experts would fairly be productive for the objective of policy. In terms of policy execution, the public agencies would act in compliance with the KAPA requirements in terms of participation and accountability. The delegation was properly schemed to exploit the workforce in experience and system. The practical team is required to institute under the supervision of deputy secretary of DOJ and to be constituted by the mid-rank officers as well as civilian experts (2005). The participation and concept of collaboration or cooperation were ensured for the effective and democratic administration of policy. The Rule mandated the registration system of private firms which could contribute a professional service on the laws, rehabilitation and clinical counseling. The accountability desired by APA could be taken account of where the eligibility to register would be reviewed. It should be a legal corporation who manages at least a larger of three 
clinics. The principle of discretion advocated by APA also reincarnated in the phase of policy execution so that it would be vested within the sole discretion of the Secretary of DOJ whether to endorse a registration. The legal corporations within the collaborative system would be offered the subsidies and compensation. The Secretary is required to review on the standards in exercising his discretion about the subsidies and compensation, which should not be arbitrary (2005). The Rule and execution of policies also triggered an uncertainty reduction which allows the interested parties remain in due expectation about the public maters (2005). The standard has focused on the assets of corporations, operational performance and outcome during the near first year, the capacities and capabilities of operation, and the merits of project bidding. The concept of accountability affords the administrative tool to attach a condition in exchange of the subsidies and compensation

\section{Reference}

A Public Bulletin: The New Rules of DOJ (2005). The Human Rights and Justice. Seoul. ROK: Korean Bar Association.

Mashaw, J.L., Merrill, R.A., Shane, P.M. (2009). Administrative Law, the American Public Law System: Cases and Materials. St. Paul. MN : West.

Stulz, K. M., Shumack, K. A., P. Fulton-Calkins (2012). Procedures \& Theory for Administrative Professionals. Mason. OH: Cengage Learning. 


\section{About the Modern Bureaucracy}

\section{The Nature and Concept}

Given the striking influence of rulemaking in the contemporary public administration, we would contemplate how the rulemaking actually progresses or occurs. In other words, what factors or in what ways the rulemaking would be processed by the public agencies or impacted in any results as consequential for the public lives of citizen. The first question in this concern, and as supposed to be the topic of this week, would be how we see the actors or players who realize the rulemaking. We generally term this class of modern administrators or policy makers as bureaucrats. The bureaucracy would be a dimension and social designation to denote the conglomerate of institutions, norms, personnel resources, public instrumentalities and public entrustment in the modern administrative state. The term originated from the German sociologist, Max Weber, and a scope of insights had been received about the essences or moralities within the capitalistic paradigm of administrative rule. His thought marshaled the lassiez-fair of capitalistic prosperity into any ordinate, virtuous, eclectic, interactive, or sound and moral regime, who considered the role of government as central and typified in cores as bureaucracy. The bureaucracy principally would imply the government or executive mostly, but would be a creature of social nature beyond the mechanic or autonomous governing authority. The bureaucrats in this aspect would transcend the concept of agencies or offices defined as a matter of law. They are neither a pure instrumentality to perform the constitutional or statutory responsibilities, rather the social elites or cultural or social egos to administer the societal value. In the Weberian purview, the societal value is entwined dominantly with the paradigm of capitalistic production but to be recast with the highlight of ethics, morality and public virtue or goodness (Gajduschek, G., 2003). Therefore, his idea would pioneer comprehensively the legal, moral, or institutional reanalysis of the thoughts of liberal capitalism, which gears up to view or yield the better realities of capitalist society within any social context.

First, the bureaucracy could be seen as an organizational phenomenon, and it could be identified as the formal-rational organization. In purview of G. Gajduscheck, it would function for the public good of uncertainty reduction and the value, "rationality" could come from its very nature, although it would not guarantee an efficiency in the modern view of ideals on the public administration (2003). This attribute has been strongly emphasized in the disciplines of organizational theory, organizational behavior, and management. This understanding could be identified in the evaluation of Weber's model as a descriptive version of the Taylorian organizational model. Therefore the elements dealt with by Taylor and Fayol, such as the division of labor, specialization, strict rules-codifying the one best way-strict subordination, and exclusion of any personal element from the conduct of work, could well characterize the modern bureaucracy.

The modern bureaucracy may be described as a system-specific mechanism (2003). In this concept, we can explicate the dynamism or force of individual utility maximization principle in the bureaucratic practice. It is true that the complexes of modern democracy have brought the uncontrolled spheres or personal interests into any factor to execute the roles of bureaucrats. This view can be profiled with the neo-classical economists who consider it as opposite with the free market. Then the bureaucracy would be one behemoth of nonmarket, and with no clear and immediate feedback on the efficiency of activities and outputs. 
However, it has to exist since the bureaucracy is responsible to correct the market failure (2003). In the basic approach of bureaucracy, I believe that two concepts should intervene in thinking about its role philosophically and at its very basic, which would be rationality and uncertainty reduction. Provided if the efficiency is an ideal of market economy, the two concepts address the nature of bureaucracy. In his argument, we misinterpreted the Weberian concept of bureaucracy as the efficiency-pronged institution which would be false. Rather, the bureaucracy, as an institution or organization, needs to be viewed to take an eclectic role as the rationality and certainty-reduction oriented proclivities (2003).

\section{The Rulemaking and its Impact: A Theoretical Purview}

From the nature of bureaucracies, we can have a good guess that some combination of law, information, politics and management ultimately determines every rulemaking effort. Although we are hardly the first scholars to identify these factors as important and note their interaction systemically, it would vastly be true in our routine experiences. The officers under the command of his superior would respect a direction about the specific issues or problems. However, any more plausible or persuasive information he holds in his professional life would stimulate a consult or communication to change the mind of superiors. Both may assume the suggestions or implied demand of politicians as primary since their ultimate accountability rest within the constituents and the elected officials represent the wishes of constituents. They also see importantly the organizational aspect of their units or branches. Because of these factors, they could not continue on the public project due to some fiscal deficiencies and the desired rule perhaps should be withdrawn or shut down. This could be said of general influences which impacts on the rulemaking, and the comment form $\mathrm{K}$. Hawkins \& J. Thomas would give us a maxim that the studies of bureaucracy or rulemaking would be complex as subject to a variety of legal, political and bureaucratic constraints. The sociological or institutional work on bureaucracy also would give us an insight, for example, bureaucratic maze and moral arguments or types of leadership leading to the success of organizations, or efficiency and efficacy about the forms and structure, as well as the affirmative action to recruit the minority officers, and the like.

In this concern, we can illustrate two fundamentally opposing school of thoughts in understanding the ways the rulemaking is impacted (Kerwin, C. M. \& Furlong, S.R., 2011). One is the bureau dominance theory which perceives the role of bureaucracy is primary. The bureaucracy would dominate the rulemaking process and in terms of determinative leverage to produce the final outcome of rulemaking (2011). This theory considers an importance of modern bureaucracy in creating or implementing rules, and views it as autonomous, independent, creative, and final in substantial interplay (Kolber, M. (2009). The separation of powers principle would strengthen the basis of this argument if the executive or bureaucrats are preserved with the exclusive role and constitutional power. The theory also corroborates with the paradigm of modern administrative state that the bureaucrats often could be described with the adequate expertise and professional experience in their specific field. In this purview, the role of head of agencies should be relatively powerful and dominant, which would diminish in the second ways of impact, i.e., principal-agent school. First, the head of agencies would exercise a determinative role in shaping the public policy or rules by way of the command authority and institutional powers to correct. Second, the head of agencies would increase the informal network and could make the bureaucrats as some of prestigious. This could impact the rulemaking in any positive way on one hand, but may procrastinate on the progress and undermine a democratic sanctity. The bureaucratic maze may be prone to 
make them as secular or even corruptive, but their professionalism may be boosted in pride to make a positive impact on rulemaking. The principal-agent model would explain the ways to impact on the rulemaking entertained by the bureaucracy (Harrington, C. B. \& Carter, L. H., 2009; Kerwin, C. M. \& Furlong, S.R., 2011). This model generally regards the role of bureaucracy as secondary or subsidiary that the agent has to bear their public responsibilities as subject to the will of principal. In this case, the principal could be circumscribed in concept as citizenry in a bigger picture, and congressmen, president or Supreme Court Justices whose offices immediately or indirectly represents the sovereign people. Therefore, the agent would be merely the class of public officers entrusted with the life, liberty, and property interest of people. Therefore, the ways of rulemaking should operate seriously to respect the interest of people, and any ultimate context of factors is required to arise from the principal who impacts profoundly the rulemaking process and its outcome. This view could be considered as classic and espouses the idea of modern constitutionalism and democratic virtues. In this case, the role of head of agencies could be disposed in two basic ways. First, their role in rulemaking would be conservative or normative, hence, he or she would be prudent about the norms and basic structures of law and bureaucracies. It could create the society with less regulation where the firms or enterprises could find more opportunities and prefer to invest. Second, the head of agencies may fail to respond with the advances of society which generally requires a leadership role of government beyond the responsiveness and loyalty to the will of principal.

The role of head of agencies needs to be thought in view of the congressional delegation of authority. The scope and extent of leeway in exercising a discretion, hence, the extent of agencies' authority would be defined from the delegation. I agree on the research findings that the managerial capacity of agencies influences the volume of policy authority that lawmakers delegate (MacDonald, J. A., \& Franko, W. W., Jr., 2007). From the work of MacDonald \& Franco, we can confirm our general holdings that the congress would take account materially of the performance of agencies in contemplating a delegation (2007). The possible policy conflict between the legislative and executive branch would lead to this understanding so that we can analyze the findings in resonance with the head role and two theories. The head role would be any more important to grow their agencies and organizational competence as well as extent of reach or authority. Given the accountability from rulemaking and its implementation finally lies within the head of organizations, his role would be critical in interaction with the political branches. The research findings that the poorly performing agencies are more likely lose policy authority and the congress would give an incentive for effective policy making reveals the current context of principal-agent modality. Nonetheless, it does not contradict the hypothesis of bureau dominance school since the congress massively delegates and defers to the practically steering role of modern bureaucracies.

\section{The Delegation Doctrine, Its Necessities and Normative Limits}

The delegation doctrine shields from an unconstitutional paradigm of public power designed and bestowed by the Supreme law of land and among the coordinate branches of government. The legislative power in its immanence and essences requires that the bicameral institution would be a fundamental body to shape the public policy. A discretion and leniency are intrinsic in the legislative power vested within the Congress. The power to enact laws, therefore, should not be delegated to other branches. Otherwise, it would be repugnant to the Article I of Constitution. The delegation of legislative power would be necessary and inextricable for several reasons. First, the state matters and agendas increasingly became 
expansive from the economic, scientific and technological advances and social transformation. The legislative body would not be all-mighty competent to resolve the public issues and contentions in its sole capabilities. Second, the resources of Congress are not sufficient to deal with every details of public issue or problem, but they find it apposite to hold the principled statute with a delegated power to supplement via rulemaking or interpret to address the specifics of enforcement (Harrington, C. B. \& Carter, L. H., 2009). Third, the experiences and expertise of administrative agencies could more properly operate to deal with the challenges and the problems of constituents in a concrete fashion. The Congressmen may like to endeavor on the political negotiation and communication with the constituents while leaving the practical details cumbersome or hardly handled on their own to the discretion and hands of administrative officers. In this way, they may avoid a harsh reaction from the policy failure and can save their political lives from a criticism as well as an intense conflict or antipathies. Fourth, the collaboration and interplay could be ensured as we know a like concept, the iron triangle, among three actors, say, congressional commission, private interest group and pertaining bureaus or departments of government (Kerwin, C. M. \& Furlong, S.R., 2011). It could fill the gap and save from a possible stalemate arising from the stringent system of separation of powers principle. Fifth, the rule of law ideals could be enhanced by the delegation of legislature and rulemaking undertaken by the executive body. Without the delegation and if with no rules to execute the law and public policy, the status would create a risk that the standards or consistency of enforcement would be non-existent because of the natural abstraction and insufficiency from details. A cross-check and double-guarantee could be promoted among two political branches and as multiplied to ensure a responsible government by the judicial control. The delegation doctrine, nonetheless, would face with the constitutional challenge in terms of structure and authority (2009). The judiciary turns to recognize the necessities of delegation in response with the increasing virtue of administrative state (Iancu, B., 2012). The impact of delegation doctrine on the public administration is tremendous that the Federal Register has thus far compiled a massive of rules to affect the American public lives routinely (Laureate Education, Inc., (2009). Nowadays, typically around the 1970's, we can safely say that there virtually would exist no public statute embodied by the Congress and without the public programs being associated. Second, the delegation from the Congress would impact to alarm and enable the administrative agencies to play on the public problems or issues triggered. The modern practice of government, as said, could have a focus on three players in terms of iron triangle (Kerwin, C. M. \& Furlong, S.R., 2011). The private interest group would play a lobbying and intends to reflect their voice in the public policy making process. The congressional commissions or sub-committees exchange the views and assessment, in an intimate context, with the administrative agencies so that they facilitate an identification of public problems and feasible solution to respond with them. Third, the legislative delegation is required as a matter of constitution and law to provide the intelligible principle which the agencies respect and comply with (2009). The standards or guidelines legitimate a delegation so that the principle of predictability and clarity or certainty has to be ensured. The extent of generality or that of specificity could be articulated to make the delegation as superior and excellent as we learn in the case of Federal Sentencing Commission. Therefore, the impact of delegation on the administrative branch elevates its public commitment with a compounded effect and hybrid nature of endeavor on the laws, prescription and expertise. The Congress and President, in this purview, are required to give a specific direction not only as a matter of control, command or organizational leadership, but also from the constitutional mandate or bounds of legitimacy. 


\section{A Policy Area and Delegation Doctrine}

One important area related with the delegation doctrine would concern the criminal policy and statutes of the kind. That is partly because the punishment has a tradition of abusive state power to persecute and suppress. The dictatorship or tyranny over history had been particularly problematic of the inquisitive system, torture, cruel and unusual punishment, as well as a miscarried jury system forfeited of the fair selection and tainted with a prejudice or distorted influence over the juries. In the United States, the act was embodied to organize the Federal Sentencing Commission in purpose of the balanced criminal sentences among the same or similar crimes and criminals. The Congress perceived it fairly contravene the equal protection of laws and obstruct the sense of equal justice across the cases, yet to be generally conceived or held by the citizenry. It would undermine the integrity of national criminal system, and the respect of laws or attitude to comply with the laws could be damaged because of the unfair enforcement of criminal laws. This area of concern actually is fairly sensitive that the stringent standard of criminal enforcement often prevails. The case, titled Mistretta, however, entails two important issues involving the structure and authority of Constitution, in which the criminal analysis would lack. Instead, the court reasoning argued intensively on the nature of statute, and manner or extent of prescription whether it sufficiently details the standards or guidelines, hence, if to meet the judicial element of "intelligible principle" so as to legitimate such delegation. The Court view endorsed its extent of generality and specificity to suffice the element (2009). The statute, according to the court opinion, properly defines the general appropriateness and general inappropriateness to shape a sentencing guideline and policy. The Court, on this basis, illustrated a major feature of Act which covers the sentencing range, use of current average sentences, seven factors in its formulation of offense categories as well as 11 factors in establishing the categories of defendants. Along with other complements, the Court considered that the Congress provided an overarching constraint and that any abusive leniencies or impermissibly extensive latitude in enforcing the Act would be properly prevented. Other arguments were brought to contest the value of judicial independence and the matter of discretion or leeway each trial judge is allowed. In other words, the separation of powers principle was questioned in which the court rejected the plaintiff's proposition. However, the dissenting opinion filed by Justice Scalia seems to have a repercussion so that the majority ruling in this case may propel the legislative delegation to flourish and even to expand onto the private nature of public institution, such as medical commission and the like (2009). The proclivities will possibly degrade a fair and sacred exercise of state power to complicate the constitutional paradigm. In any case, Mistretta showed the importance of clear direction and adequate standard that the delegated agencies could apprehend and cling to be consistent or consonant to deal with the challenges and social problems. On the other hand, the Korean practice of constitutional court also proves the importance of delegation doctrine in terms of criminal justice. Many precedents underpinned the issues of permissible delegation involving the national criminal policy. As said, that is because the principle "nulla poena sine lege" had been deeply rooted within the criminal justice system. Therefore, a stricter review would be undertaken in comparison with the acts concerning other areas of public policy, such as welfare and economic regulations.

\section{Reference}

Gajduschek, G. (2003). Bureaucracy: Is it efficient? Is it not? Is that the question?: Uncertainty reduction: An ignored element of bureaucratic rationality. Administration \& Society, 34(6), 700-723. 
Harrington, C. B. \& Carter, L. H. (2009). Administrative law and politics: Cases and comments (4th ed.). Washington, DC: CQ Press.

Iancu, B. (2012). Legislative Delegation: The Erosion of Normative Limits in Modern Constitutionalism . Heidelberg \& New York, FRG : Springer.

Kerwin, C. M. \& Furlong, S.R., (2011). Rulemaking: How government agencies write law and make policy (4th ed.). Washington, DC: CQ Press.

Kolber, M. (2009). Rulemaking without rules: An empirical study of direct final rulemaking. Albany Law Review, 72(1), 79-115.

Laureate Education, Inc. (Executive Producer). (2009). Fundamentals of law and public policy: Administrative agencies - Authority and enforcement. Baltimore: Author.

MacDonald, J. A., \& Franko, W. W., Jr. (2007). Bureaucratic capacity and bureaucratic discretion: Does Congress tie policy authority to performance? American Politics and Research, 35(6), 790-807. 


\section{The Administrative Enforcement and Oversight}

\section{Sanctions and Techniques}

In response with the need to ensure a compliance, the administrative agencies could rely on the types of administrative sanction and technique. Two spheres could be made distinct : (i) retributive and preventive v. post-remedial and command-related (ii) forfeiture of rights or interests v. regulatory (iii) completely statute-based v. extent of flexibility and so. I intend to explore two spheres from the comparative viewpoint across the types of tools.

A first way to countervail and remedy a non-compliance would be cutting funds or other financial aids (Harrington, C. B. \& Carter, L. H., 2009). The public programs in the provisional state would employ a method to fund in the purpose of allocation of resources and to encourage the activities of public good (Iancu, B., 2012; Schoenbrod, D., 1987). For example, the segregation of different races could be more effectively enforced with the subsidies or funds than the compelling order of Supreme Court rulings. The promotion of research activities and boost of national science may be gone in this way in which the federal agency reviews the research proposals and provides grants. In some cases, the state government may benefit from the federal funds if to be subservient for the goals of federal government. In these cases, cutting funds or other financial aids would be any best way to draw their compliance with the terms and conditions for the grants or funding. It would be a great way typically in the policy areas of federal provision or financial support. This would be a most updated of enforcement tools when we compare with the rest of them. This policy tool particularly could well function in the context of dual sovereignty between the federal and state governments. The contemporary practice of federal government generally considers the grant of funds as a tool to extract the loyalty and compliance of state governments for many federal purposes. A regulatory context could have a ground on the federal supremacy, but its scope tends to generally retract lacking no federal police power theoretically. Hence, the federal government can entice and impose a requirement with the federal provisions.

A second way to enforce the purpose of statute or administrative rules would impose a sanction to result in the loss of license (2009). A license would exist in the extended scope and formality which could bridge or liaison the businesses or professional activities with the regulatory authority. For example, the driver's license would legalize a driving within the state which requires a certain skill and basic knowledge of traffic regulation. A business license for liquor shops permits the business activities to sell an alcoholic beverage and profit from the sales. A construction license could serve a variety of public purposes covering the safety or technological standard, adaptability to an existing urban zoning, pollution or environmental healthiness and the like. A professional license, for instance, bar, medicine and pharmacy, also serves to maintain the public standard and expectations. This enforcement tool would be semi-classic or regulatory as traced back to the earlier centuries, but in the times when the social base of production could put a deal onto any public order or system. The enforcement tool along with a criminal sanction is rather deep and fundamental to eradicate the base of operation, which is more severe and depraving than others in terms of the proportionality principle.

The administrative agencies may utilize the types of sanction, i.e., administrative fines, criminal sanction and economic sanction (2009). These tools are highly imposing and take the nature of divesting the interests and privileges of actors and players. The administrative fines could be distinguished from the criminal fines in that a stringent element to incriminate would be unnecessary in the former institution. The intent or recklessness and 
other kind of mental element, often called a scienter or culpability, to impose the criminal sanction would not come as a prerequisite. An objective conduct or act, in some cases, only a result, could alone constitute a legal basis for the administrative fines. The criminal sanction in the sphere of administrative law and rules would be scarce and limited, which could only be enforced in response with a serious obstruction of administrative goals. The APA illustrated an economic sanction in the last of list. It could be opted for by the agencies whose programs involve the financial decisions to achieve policy aims. One notable example arises in the Carter administration, who intended to make procurement policies a part of its inflation-reduction strategy (2009). In pursuit of effective enforcement, agencies were encouraged not to purchase from those who had significantly raised prices. In other programs, the minority participation was envisaged as an important policy objective, and the former Department of Health, Education, and Welfare applied an economic sanction involving the community development funds. The tax exempt status or its denial would make a good case of economic sanction that the IRS could ensure a compliance of its policy goals concerning racial segregation (2009).

The techniques would include the consent settlement, industry guides, cease and desist order, advisory opinion, as well as the affirmative disclosure and other corrective orders (2009). The consent settlement normally would lead a higher rate of compliance if the agencies and target person or organization would negotiate and form a voluntary consent about the controversies or ambiguities. A most of implementation by the agencies often would be autonomous and involves a mechanic application of laws so that they focus a first look on the permissibility of negotiation and consent-based resolution. Therefore, they have to figure in the nature of command and statutory provision or rules whether the enforcement is mandatory and does not submit to the will of involved parties since it entails an issue of public order or serious public interest. In any case, absent any contrary mandate or legal requirement, the consent settlement would be some popular technique the agencies could rely on. The industry guides may have a de facto and rarely de jure force to impose the duties and standards (2009). Given that the laws and rules cite it in the provisions or clauses, it could combine to constitute the whole of legal duties. Otherwise, the private businesses and enterprises would highly be recommended to abide by it, in which their non-compliance or neglect would possibly effect that the professional network and interaction with the government could be degraded. The industry guides may share commonly with the consent settlement and advisory opinion that they trigger a voluntary compliance as the soft form of enforcement techniques. Nonetheless, the technique is intended for a specific industry at large and in generality while the consent settlement often would be party or individual-specific. Despite this, the APA requirement of notice and comment procedures would not be necessarily followed because of its non-binding nature generally. This aspect actually depends on each authority, however, as we see in the case of FTC. A soft nature of technique found in the industry guides could be distinguished from the cease and desist order or other corrective orders. The agencies use an advisory opinion when a party seeks information regarding the lawfulness of a proposed action. In this case, the internal procedure may be arranged to give an order to the process. The cease and desist order would be a part of adjudication, but not all orders fall within this category, which would be affirmative, negative, injunctive or declaratory in form 551 (6) (2009). Adjudication, according to section 551 (7) of APA, means agency process for the formulation of order. A cease and desist order, sometimes called a negative order, specifies certain actions without any punishment but with the added costs of hearing, which the party must not take in the future (2009). The affirmative disclosure and other corrective orders would be used to correct the misleading ads and 
promotional materials in case where they seriously undermine a right apprehension of customers. The FTC frequently used this technique which would largely yield an extent of effect on the enterprises, which practice some intense or wider scope of public relations. This quality of use characterizes it from other techniques when we see in J. B. Williams Co. and Warner-Lambert Co. (2009). According to the order, the businesses or corporations are compelled to make a statement as directed by the FTC and Court or to correct their previous statements. The order to correct and affirmatively disclose, however, should not be punitive unless the activities or public relations were pursued in any deliberate deception and bad faith (2009).

\section{Some Insights}

From the text, we could learn the issue of compliance, factors to weigh in the compliance, types of enforcement tools, as well as the nature of sanctions and administrative techniques to increase the rate of compliance with the laws and public policy (2009; Laureate Education, Inc. 2009). The laws and public policy ultimately consummate at perfect compliance, which would be unrealistic in the secular world. The principal duty of administrative agencies from the Constitution and the laws of land is to create the public policy via a rulemaking authority and to implement it (Iancu, B., 2012; Kerwin, C. M. \& Furlong, S.R.,; 2011; Schoenbrod, D., 1987). An implementation may confront a noncompliance of citizen or actors against the ambit of statutes or public policy which raises our concern of how to enforce them so as to ensure a public good, such as public peace, the goals and intention of legislature, social justice and order. Therefore, I may state that any most important insight we could extract in the enforcement would be to maximize the public good by ensuring a high rate of compliance and without an infringement of the laws and rules. That could be made successful that the agencies would squarely assess four central factors, i.e., rules, enforcers, beneficiaries and regulated parties.

My second point would like to stress the importance of respect for a set of principles on the public laws and transparency of enforcement. The enforcement techniques would deal and make an effect in more flexible manner than the tools of sanction. Types of enforcement technique would range in the wider spectrum, but could not be approached in any concealed, implied, influential, or coercive way. We regard it in purview of the rule of law ideals, not rule of man nor unfounded hierarchy. In view of the enforcement of law and public policy, the administrative agencies are deemed superior to rule, order and command. That, nonetheless, does not mean that their adjudication, rulemaking, discretion could be unconstitutional or illegal. If the acting or contemplating space of modern administrative agencies became rather extended in terms of its scope and leniency, the Court would often defer to the administrative discretion. In this concern, we may, however, consider the principles of clarity, certainty, proportionality, consistency, as well as a value of vested rights and the like. For example, the principle of proportionality may require a balance of interest between the harm of misconduct and extent of sanctions to redress it. A serious offense of drunken driving may deem it adequate the loss of license. However, such extreme penalty would not be sustained in the case of parking violation. A small amount of administrative fines could do any public good on the proportionality principle. The consistency and certainty would play as another standard in the process of enforcement. The expectations of citizen duly formulated over the bulk of time and with the practices or enforcement of agencies should be honored. A contrary enforcement or administrative decision often is desired to minimize as possible extent. Over the techniques, one important note has to be emphasized that the executive or administrative agencies execute their duties in any consistency and to 
the mutual satisfaction of parties, but without the violation of law. If they once respond with certain advisory opinions, the practice generally would be certain to hold its effect through the times. The soft form of enforcement techniques, therefore, does not necessarily mean that it could be capricious or frivolous to obstruct the predictability and reliability of public administration.

\section{The Three Branches and Oversight Mechanism}

We can view the oversight mechanism in response with the arguably principals of administrative agencies. They firstly would be accountable to the Congress whose role is lawmaking as creative and seen as primary organ to generate a basic public policy. The Congress has managed several of important oversight tools which would be money or appropriations at first instance, legislative veto or corrections day secondly, deadlines or hammers in the next, and others (2011). The important point of differences from other mechanism arises from the separation of powers principle. The Congress could only be empowered to check and balance the competing powers. They could not overrule an independent preserve of executive function, which comes in comparison with the Presidential oversight. Although the administrative agencies would be termed as fourth branch, it merely would elicit an apparent or practical role lacking any definite normative ground. Hence, they generally are responsible to the presidential control in any absolute context and in his line authority as well, whose attribute would not be shared by the Congress. In other words, the oversight of Congress could not exceed a constitutional or statutory ground, but be bound by it. Otherwise, the action or resolution of Congress would be rendered unconstitutional in terms of the check and balance mechanism of Constitution. The oversight of Congress also needs to be made distinct from the judicial control since the judicial oversight could only intervene on the case or controversies requirement. Only a dispute on the concrete harms or loss, as related with such ripeness and mootness doctrine being operative, could come under the judicial review. Those could be an indispensable element to reduce the chances or extent of judicial engagement. The Congress, on the other hand, could entertain a more flexible initiative to check and investigate the administrative agencies in the end of oversight. The popular quest to investigate may ground their action, or the enabling statute may institute the conditions in an ample discretion of Congress about the chance of review or oversight. The final destination of oversight mechanism may differ if the authority of Congress would be dubious if to dispose or deliver their intent specifically. Often the congressional resolution in the purpose of oversight would lead to some additional work to execute and implement on behalf of the administrative agencies. This quality generally would not be present in the judicial control or presidential oversight program. The first two oversight mechanism would share the similarities since it would be flexible and fall within any extended scope in view of the available measures, which would largely be soft or provisional in nature. For example, money or appropriations and corrections day could work to encourage or discourage the action of administrative agencies (2011). The measures would be provisional, but critically circumscribe the plane that the agencies could construct, coordinate and implement. The institution of corrections day shows an ingenious dealing of Congress to impose their policy goals which would differ from the judicial control. It, however, could be done same way in the Presidential oversight. This context would hardly be possible in terms of judicial oversight. Another illustration would be helpful in understanding the creative way of oversight institution which is the 1995 Congressional Review Act (2011). The Act would reinforce the congressional veto, but as accorded with the court rulings. They could utilize the 
president to involve constitutionalizing the congressional review and added the process of joint resolution to respect the court opinion. This kind of post-revamp could not be conceived in the context of judicial oversight. It is similar that a flexibility or creativity of oversight could be in more chances when we see the presidential oversight. Nonetheless, it also faces with a constitutional or statutory ceiling since the President is a principal officer to execute the laws of US.

\section{Two Most Effective Oversight Mechanisms}

In my point of view, money and appropriations bill or language would be most effective in terms of the congressional oversight. The OMB review could second this point of salience, typically aided with the intelligent peers within the Executive. According to one empirical study, the public schools would more willingly comply with the segregation requirements not because a court ruling mandated, but because they could satisfy the conditions imposed by the federal government to dispense with the financial assistance. The Congress may increase the intensity of procedural means to oversee, and may stack the deck of agencies' policy in favor of constituents' interest (2011: Headrick, B., Serra, G., \& Twombly, J., 2002). The procedural requirements may ensure a moderate bureaucracy in comity and respect of constitutional value, but the administrators may merely intend to rig the rules to favor their institutional goals and need. Twin veils of substantive vagueness and procedural complexity often attributed to the congressional acts or statutes still fail to be completely resolved. The deadlines or hammers, for example, in the case of Resources Conservation and Recovery Act, may extract a loyalty and faith to expedite the congressional goals, but could be misused in the distract way and to serve the political purpose (2011). This mechanism could be satired in nature, say, the kind of "oxen's susceptibility to goring." It pays, however, that the oxen may be driven to serve their scheme or wishes. In this case, the deadlines may be hopelessly unrealistic, erratic, superficial, politically motivated, and largely ineffective. M. McCubbins \& T. Schwartz posited two interesting classes of congressional oversight, which are a police patrol and fire alarm variety (2011). One often would be skeptic if the congressional oversight would be any most effective as said of the deadlines or hammers. Nonetheless, the view of two scholars demonstrates a variety of causes to play as an overseeing authority. It would actually a mind-boggling prospect that the congressional oversight could be framed in comprehensiveness. The mechanism to oversee based on money or appropriation bills would make an effect in that (i) the organizational context of agencies would highly depend on that variable (ii) it could signal the support or distaste of Congress about their public project or program (iii) the public programs and financial sources to pursue their policy goals includes a system and institution as symbiotic each other and would be a matched roadmap to define the agencies' commitment (iv) they could be encouraged in morale or discouraged seriously which could tame their disobedience or correct a neglect and abandonment (Headrick, B., Serra, G., \&Twombly, J., 2002). The importance or sensitivity of money or appropriations could be ascertained with an occasionally inverse relationship between the rulemaking responsibilities and funding in the appropriations.

This benefit from the financial tools can be reaffirmed in the practice of OMB and ORIA. Other factors could be added that the executive branch could maintain their own integrity in coherence and the professional staffs from a multiple pool of expertise could reinforce their measure as merited and lawful to yield a best result. The presidential oversight program, however, would shift on the basis of partisan politics. A limited review would be favored in the Clinton administration, but the selectivity in review would positively profile toward a quality process of oversight (2011). The review time performance would not be 
consistent, however, varying with the respective presidency and issues involved (2011). The practice of deadlines to complete a review would not be purely intramural so that a negotiation with the Congress and requirements should be respected in the end of workable government (Hissam, M., 2008). The Congressional Record in November 1989 includes a detailed version of an "administrative agreement" between Congress and the OMB, which concerns a regulatory review procedures and information disclosure. The assessment of $\mathrm{H}$. Bruff would divulge four advantages that the OMB enjoys in the review process: the power of persuasion from the cogency of its positions and the power of those asserting them (ii) the power created by the threat of delay (iii) use of political appointees for an allegiance to remove the conflict with the white House policy (iv) completeness to forge its oversight intention with the budgetary power (2011).

\section{Some Concluding Insights}

The oversight of administrative agencies is a necessary mechanism to ensure its legitimacy, efficacy and consistency not only to produce a maximum extent of public good but also to practice the constitutionally or structurally coherent system of public administration. We may consider the primary goals of this oversight mechanism in two perspectives (Laureate Education, Inc., 2009). First, it would ensure the constitutional values as the Court in Chadha elucidated. We could tolerate all the obvious flaws of delay, untidiness, and potential for abuse in exchange of ideals to conform the administrative practice to any defined or systemic institution and due context of constitutional process (Harrington, C.B., Carter L.H., 2009). The statutes desirably would facilitate a public interest in the wisdom and function of administrative rules, which, however, would be bound by the procedure and constitutional requirement (Bowers, J. R., 1989). An accountability to the Congress or judiciary would be deemed to advocate and should be procured in this point of emphasis. The concept of agencies' accountability in this direction would resonate with the principal-agent school of thoughts where the issue of structure and authority would speak much and the factors to be respected by the agencies arise from the loyalty and obedience to the popular will or branches of constitutional and democratic representation (Kerwin, C. M., Furlong, S.R., 2011: Lee, M. 2011; Pelizzo, R., 2013). Second, the oversight mechanism could correct a failure or weaknesses of administrative decision or action in terms of the efficiency and public interest. This policy control could come into three slots of occasion, which takes a different phase and attribute. For example, the judicial control would be distinct that they could not make an immediate or direct impact to correct the measure in the abstract and general fashion. A contrary finding against the administrative action would only govern the case at bar. This doesn't mean that the practical consequence would be same to theory, but the court ruling would often be determinative so as to lead a voluntary configuration of policy by the agencies. The congressional oversight would also be independent since its constitutional role would go as multifaceted in terms of interbranch interplay and structure. One notable illustration stems from Chadha in which the Court finds the statute unconstitutional on the ground of the bicameralism and presentation clause. The Attorney General's decision must be classed as legislative in nature and the post-decision review by one House is commensurate with the legislative function. Then the presentation to seek a presidential signature to make the bills into law is indispensable which the statute actually lacks. In lesson from the judiciary, new initiative resulted in the Congressional Review Act of 1995 in which the joint collaboration of bicameral organs to involve overseeing the administrative measure and the President would convene to make a summary 
process in lieu of formal signature requirement. Therefore, the legislative veto still survives in two types, i.e. approval and disapproval (2011). This post-context of legislative control would be a most desired form of oversight mechanism as accords with the transformative concept of modern Congress. An investigatory hearing or special sessions to check and monitor the function of other branches would exceed the traditional law-making function in terms of the power list or province of Congress. Third, the oversight mechanism would increase the efficiency or fitness within the grand scheme of national administration. This point of public utility could more directly be brought into reality by the oversight program of President (2011). The administrative agencies would grow to be termed as the fourth branch in the politics of United States, which means its immense effect on the public lives of citizenry. They are typically experts in the specific field and the branches or units are often staffed with the scientists, lawyers and professional administrators. For example, the Food and Drug Administration would employ the specialists and researchers of chemistry or pharmacy policy who would play an important role to provide a scientific information. That could be encouraging, yet to be coordinated by the operation of presidential oversight program. In some cases, the ambitious public programs may be turned down as adapted with the more compelling interests of national economy or others. A basic tone of partisan stance in terms of politics and public values may be ensured by the presidential oversight. The statistics shows a correlative between the two major political parties about the extent of oversight program. For example, we can note that the Reagan and Bush administration would see it deepened and broadened (2011). The dimension of efficacy or fitness would be related with the bureau dominance school in view of basic perspective on the public policy-making and execution. The concept of inertia, bureaucratic maze or moral frames of bureaucracy could pertain to this aspect of oversight mechanism.

\section{Some Thought on the Importance of Oversight}

The impact of oversight mechanism on the agencies would be fairly governing that they would squarely be affected by and symbiotic with the oversight authority. The quality of oversight impact could be classed in two ways, which would be formalistic and qualitative. The legislative veto or judicial control would be formalistic so that the agencies would be bound as a matter of law. They have to seek a congressional approval to legitimate their decision or disposition, or could be disapproved even if they create a rule and execute the laws and public policy. That would be a legal consequence that the Congressional Review Act 1995 would mandate, which was revamped in response with the Chadha Court (Kerwin, C. M., Furlong, S.R., 2011). The judicial review also formally endorses or nullifies their action which would guide the agencies to conform with the requirement of Constitution, law and legal principles. This concern often comes paramount if the rule of law would be supreme standards to be respected. The failure or ignorance of law would attract any hotter criticism or satire from the public, and seriously harms the reputation of agencies or bureaus. Often notable public offices or agencies would avail of legal expert team to screen any potential flaws of policy in terms of law and Congressional approval. In some cases, the agents or public officers may be subject to the civil damages under some stricter requirements of tort law. The state or federal government would not be immune if they would highly be culpable, as commensurate with "intentional, reckless or grossly negligent" and if the action was performed under the color of government. In due conditions, hence, the state immunity act would not apply, instead, the tort damages could be imputed. The kind of formalistic impact would generally be basic and impliedly operates curbing the arbitrary role of agencies 
in execution of their duties and professionalism. That underpinned their engagement, though not frequently surfaced to the public attention. The head of agencies would typically be concerned of this basic issue since their role and position would topple the final delivery of public policy and would often exercise reviewing a general context of policy consequence with a wider and general perspective.

The impact of oversight mechanism on the agencies could be qualitative, which means a susceptibility of impact involving diverse variables and factors and occur in any undefined way. For example, the qualitative impact might be discerned in personnel affairs if the oversight may lead a disadvantage of officers or head of agencies in terms of promotion. It might be entwined with the reduction of their programs or cutting funds and financial assistance (2011). They could not be gauged in any formalistic yardstick, but interconnected with the wisdom, discretion, better scientific view of bureaus or agencies with which the oversight authority and agencies are entangled to produce a maxima of public good. Typically, the oversight program of president would be pursued in this context and the OMB or OIRA would play a central role to best serve the citizens and interest groups. Interestingly, the political appointees, who serve as a head of agency, would increase the trust and confidence which safeguards from the conflict with the White House policy. In this case, the impact of oversight would rather seriously affect the agencies which can continue their commitment of specific policies. Within the province of qualitative impact, we may, in some cases, find both impact be combined to influence the process of agencies rulemaking. The "Administrative Agreement" of executive with the Congress, perhaps, would be a culmination of compromise about the dismantlement or arbitrariness of deadline practice within the Presidential oversight program (2011). It then could be marshaled in a fine scheme of time schedule, and could contribute to diminish an undue delay or longer review of president. A focus of Congress nowadays seems to lie in the procedural requirements which would be formalistic. The legal effect from a procedural non-compliance, for example, delay, would be dubious, however, which perhaps differs from the regulatee's non-compliance. The statute may prescribe the effect of agencies' non-compliance in some cases, which should be crystal clear. However, that would not be such in many cases, and the administrative actions should not be deemed null or invalid if it merely delays a deadline or violates procedural conditions as secondary and set forth as desirabilities. The basic principles of public or administrative law, for example, the law of certainty or proportionality, would be deemed sustained at first instance generally across the jurisdictions. The context was discussed in Chevron in terms of the US jurisdiction. This leads to the result that only a patent and gross failure of agencies action would be struck down as a matter of judicial control. The two classes of impact on the rulemaking process practically would be consequential since the agencies are morally required to respect the rule of law ideals and pursues in goals and objective of efficiency or efficacy ultimately (Bowers, J. R. ,1989: Laureate Education, Inc., 2009). I may arrive at the view that the formalistic class of impact generally involves the rule of law requirements and that the qualitative impact would serve to facilitate the efficiency or efficacy.

\section{The Impact of Oversight on the Agencies}

The impact of oversight mechanism can be understood in two illustrations as we see this week’s resources. The Executive Order 13,422 authorized by President Bush in 2007 would shift the process and attitude or fashion of interaction with the President and agencies as well as the theme of agencies’ independence and flexibility (Hissam, M., 2008). The 
rulemaking process and requirements would also be seriously dealt in new ways, which would refurbish a paradigm as an internal control. It however, arguably would not be any revolutionary change according to Hissam, instead, to reinforce and add some new refreshments in response with the new government and as accorded with practice of partisan politics. For example, written requirements were imposed within a practical workforce including the market failure, i.e., externalities, market power, lack of information, as well as policy effect of proposed action or programs (2008). This would require of the level which warrants the validity and effectiveness of new agency action as well as the significance of problem. Hence, the calculus that agencies are required to undertake in the decision making process has changed. It also imposes the process to evidence qualitative benefits which the proposed policies could yield. They would include a square of policy consequence in noneconomic benefits (2008). The oversight would also impact the organization of agencies as illustrated in the regulatory policy officer (RPO). This officer would be one of agencies, "Presidential Appointees," and his role is to assist in developing "effective, innovative, and the least burdensome regulations” possible (2008). Hence, the rulemaking process would rather be tightened and tend to generally reduce a discretion of agencies in the rulemaking process. However, the relationship between the President and agencies would be strengthened to supplement the role of agencies as a fourth branch. On the other hand, the relationship among the head of agencies, RPO, President and Congress as well as their role or responsibilities would get to be blurred or ambiguous with this new system. As the role of agencies is important, two questions need to be addressed if the Senate confirmation is required to appoint and whether independent regulatory agencies also must designate RPOs (2008). In this point of view, the issue involves a structural issue and also matters with the independence of agencies. The rulemaking process in this case may variegate with the new requirement of mandatory estimates for the cost and benefits of regulatory action. Another change in the oversight purpose would be the issuance of certain guidance documents issued by administrative agencies about which the OIRA conducts a priori review of significant guidance documents (2008). It may demand additional consultation. These new institutions in the Executive Order plainly demonstrate the importance of oversight and its impact on the agencies, heads and rulemaking practices. Since the statutory authority would often be vague and ambiguous, the agencies actually could waffle on the sea of leniency or undefined dimension so that the role of oversight would correspondingly attain any more importance. In this conjuncture, the two theories, i.e., bureau dominance school and principal-agent thought could have a repercussion, which investigate the nature of bureaucracies. Another article from Headrick \& Twombly discusses the significance of oversight mechanism in various levels of OSHA administration, which extends previous findings within the body of work (Headrick, B., Serra, G., \& Twombly, J., 2002). It surveyed a legislative oversight and gave us a great insight about its impact on the behavior of OSHA compliance officers at the district level. The conclusion would well be supported by empirical evidence.

\section{Reference}

Bowers, J. R. (1989). Agency responsiveness to the legislative oversight of administrative rulemaking: A case study of rules review in the Illinois General Assembly. The American Review of Public Administration, 19(3), 217-231.

Carpenter, M. \& Fulton, R. (2009) Law Enforcement Management Flushing. NY: Looseleaf Law Publications, Inc. 
Iancu, B. (2012). Legislative Delegation: The Erosion of Normative Limits in Modern Constitutionalism . Heidelberg \& New York, FRG : Springer.

Kerwin, C. M., Furlong, S.R., (2011). Rulemaking: How government agencies write law and make policy (4th ed.). Washington, DC: CQ Press.

Headrick, B., Serra, G., \& Twombly, J. (2002). Enforcement and oversight: Using Congressional oversight to shape OSHA bureaucratic behavior. American Politics Research, 30(6), 608-629.

Hissam, M. (2008). The impact of Executive Order 13,422 on presidential oversight of agency administration, The American Review of Public Administration, 76(5), 1292-1307. Retrieved from http://groups.law.gwu.edu/LR/ArticlePDF/76-5-Hissam.pdf

Lee, M. (2011).Congress vs. the Bureaucracy: Muzzling Agency Public Relations, Norman. OK: University of Oklahoma Press (2011).

Laureate Education, Inc. (Executive Producer). (2009). Fundamentals of law and public policy: Administrative agencies - Oversight and accountability. Baltimore: Author.

Pelizzo, R. (2013). Government Accountability and Legislative Oversight (Routledge Research in Comparative Politics). New York. NY: Routledge

Schoenbrod, D. (1987). Separation of powers and the powers that be: The constitutional purposes of the delegation doctrine. The American University Law Review, 36, 355-389. 


\section{The Unusual Conditions}

\section{A Transition of Presidency and Its Impact}

The trade policy of South Korea would pose the challenges, which could have a potential to impact many stakeholders over the administrations in the recent decades, including the Congress, Executive, Judiciary as well as the interested groups. I like select this policy area which bears similar characteristics in terms of the agencies' rule making process and nature of issues or focus of public attention. First, the rulemaking process would confront a multiplicity of norms, say, national and international, and entails a strategic readiness or factors of negotiation and diplomacy. The nature of issues well attracts a holistic scope of industries and business sectors as well as the civic pressure group. While the national economy and international trade would be highly interdependent, South Korea would not be an exception, rather the strong profile of international trade has already been well charted. Mostly over the structure and authority, Korean system would not differ from that of American peer. The Constitution would be an ultimate authority to govern the national trade issues, and it prescribes a constitutional protocol to negotiate and conclude the trade treaty as would be disposed in the same way. The President and trade agencies would execute their role and responsibilities, which would not differ in terms of the departmental level and special agency. The international trade commission of South Korea would exercise the professional assistance, such as professional assessment or findings of damage to the domestic industry, in the interest of Korean industries. One difference perhaps only could exist that South Korea would not have an independent court, i.e., CIT, exclusively devoted to the jurisdiction of trade litigation The policy posture, nonetheless, would not be straightforward since the policy environment of South Korea on the trade issue would involve a multifaceted dimension of complicacies (Kauffman, H., 2008; Kerwin, C. M., Furlong, S.R., 2011). They would no longer claim the status of developing nations for a privileged treatment, and they would largely prefer a reason and multi-nationalism in lieu of voicing their trade power powerfully or aggressively in the international community. As a member state of WTO, the past administrations of South Korea have expressed their high wish of FTAs to boost the national economy and in response with the regional intensification of economic cooperation. An FTA with the US as concluded and now in force is one notable achievement although the presidents charged with that commitment would not be the same in the extent of eagerness and actual engagement. President M.B. Lee, in his years of reign during 2007-2012, successfully finalized it, which overwhelmed the opposing movement from the agricultural and environmental group. The new Lady President assumed the role to implement the national trade policy in new quest and according to her campaign promise in 2012. It would make an impact widely on the organizational reform of agencies and creation or alternation to withdraw the past version of rules on the national trade administration (Sapien, J., 2008; Sapien, J. \& Nankin, J., 2008). For example, a major role of trade authority was transferred to the National Ministry of Industry and Resources. The jurisdiction has shrunk which was entertained by the Ministry of Foreign Affairs. That restructuring would reflect the view of new president that an intimate interplay of domestic industrial policy with the trade issues would be any paramount than the aspect of diplomacy. Nonetheless, the Presidential transition would not be so turbulent unlike the US although we have a set of firmly embedded practice to facilitate a new inauguration (Sapien, J., 2008; Sapien, J. \& Nankin, J., 2008). The new political appointees would be bountiful to reward their aids and assistance in the campaign, and the policy team would act to restructure the system, agencies process, and so. There would it be virtually non-existent, however, that the midnight regulations may burden a 
succeeding administration. Korean people respect a maxim, "the agent would fade away as if gone with the wind.”

\section{A Change of the Rule and Agencies}

One example of rule change led by the new administration had impacted a new system of trade agencies and substantiated the concept and terms of national trade policy. It shackles or tightens an FTA implementation which is viewed as crucial for the national economy. The past paradigm was altered with new organizations, concept and contents as well as the process to respond (Brito, J. \& De Rugy, V., 2009). The purpose of new law and rule was declared clearly, "the law and rule was intended to strengthen a specialization and expertise of agencies and to maximize the competitiveness of domestic industry.” To serve this objective, the law and rule command a transfer of trade authority and competence from the MFA to MIR while the nomenclature of pertinent bureaus would change to reflect its true essentials. The new agency, Trade Promotion Commission, as designated differently in name, would perform a general review of trade issues, no matter with the scope and quality of issues, and the membership number has enlarged. Other points recommended to reform in the end of better administrative practice were reflected into a revision (Brito, J. \& De Rugy, V., 2009). Let me illustrate some of significant provisions later as prepared to meet the new initiative of Lady President and in the end to define their attributes or policy posture. The new administration would be nationalistic, conservative, and traditional on one hand, but could be eclectic with the changing circumstances or national and global demand on the other (Hammond, T. H. \& Knott, J. H., 1999). The concept or ethos of Korean clan and enclaves could be discernible, but the administration largely pursues to be responsive with the global and advanced framework. For example, the policy to raise the creative economy would formulate a new initiative to improve the paradigm of national economy. In other aspect, the proclivities to staff and employ the key offices would be conservative or traditional which made a repercussion both positively and negatively. The details of new Executive Order 315 in 2013 could be seen to serve both policy ideals that the new President embraced (Brito, J. \& De Rugy, V., 2009). It seems to be prepared for her conservative and national stance to institute a comprehensive system of trade negotiation and implementation of free trade. It follows a basic restructuring of cabinet level agencies from the Congressional act where the national context of trade impact was bought in any severe weight. In the Article 3, the EO 315 mandated to organize the Trade Promotion Committee, which would exercise a scope of administrative review. The organization is responsible to review and decide the basic trade policy, for example, the rationale and benefit to pursue an FTA or draft negotiation for the final treaty, the impact of FTA on the national economy, the public relations strategy, basic planning of prospective trade treaties, the treaty organizations mandated to create and manage, and so. As the new President prefer the practical progress and effect as well as the role of MIR, the minister of MIR and focus team would play a major role to lead this policy area. She would be conservative to watch carefully the cost and benefit, which would also be demonstrated in the social welfare policy. The new administration had decided not to enlarge the national pension or welfare benefits, rather raised a public attitude to see the cause of reduction, such as fiscal deficit and financial difficulties of national government. In the Article 7, the TPC would operate on the basis of focus team. The chairperson for the TPC would be a Minister, and the team leader of focus team should be staffed with the assistant secretary. The team members will be appointed from the rank of officers in the national government who are stakeholders of trade policy. In the Article 8, the context of paradigm shift would be supplanted with a new requirement of mandatory referral to the Cabinet 
Diplomatic Meeting. Hence, the stages of rulemaking or policy determination can be reinforced in terms of coordination and layer of collective supervision. This administrative pecking order could make it refined to adjust with the foreign affairs.

\section{The Influence of Agencies Head}

In the politics and public administration, the ways that the agencies heads influence the rulemaking process would be beset by oversimplification and ambiguities. It would not be incorrect that these uncertainties, plus incessant changes in their roles would impede the universal or long enduring generalizations for the behemoth (Kauffman, H., 2008). The perspective to make a status in terms of fourth branch would be ambitious yet to lack an adequate substantiation. In this sway and unsettlement, the political scientists and economists have continued to elaborate on the theme, paradigm and structural status of the policy institutions. The rational choice theory would be one, which offers a refined concept that the public administrators take for their course of professional performance. Despite its powerful impact generally, the theory would not be sufficient to explicate the complicacies and specifics of policy dynamism in the field. Many factors evaporate to frame the core of theirs which then must be oversimplified. The political scientists would not deem it nugatory, instead, recognize its importance in terms of their status and impact in the polity (2008). Nonetheless, their discourse would see it as a commanding partner given the political process would be studied in major emphasis on the tripartite branches of government as well as the checks and balances (2008). When we approach its dimension within the term of fourth branch, some possible classification would be envisaged that the role of agencies would be placed at two extremes, say, most active and most passive. In response with this, two theories would be a good guide to understand the role of agencies or their head, which consider it either most active, influential or autonomous or in quite opposite. A first purview would pertain to the bureau dominance school or at least help identify some active or autonomous role of agencies head. The second would come in both contexts including the principal-agent thought (Kerwin, C. M., Furlong, S.R., 2011). Another frame to investigate the role of agencies would underlie the two patterns of approach in terms of disciplinary basics. The economic mode of analysis and studies of public administration could combine to divulge the substance, ideas and realities of contemporary bureaucracy (Hammond, T. H. \& Knott, J. H., 1999). They would, however, had a trajectory of selfdom where we regrettably only could find an autonomous path to propose their own frame, perspective and disciplinary value. Its inter-linkage would be idealistic to illuminate the precise context of dilemma and its possible solution. The group of thoughts, what we call an economic mode analysis, is really distinct and exerts a fine paradigm of impact. Therefore, it would be rigorous and formal, yet to have the complementary weaknesses in that it has lacked the richness and broad applicability of the public management literature (1999). On the other, the works from the discipline of public administration are addressing many important questions, but they are relatively unconcerned with the development of rigorously defined and empirically testable models of public management (1999). In unraveling these dealings, more intense studies will do help to shape our picture about the agencies or their heads' role in practical or diverse context. The Allison model would attempt to link the theoretical standards of public action, such as rational choice theory, with the real dimension of practical contingency. The key question here would be posited in this way; "To what extent the agencies' head could make a significant decision in the rulemaking process? Hammond and Knott suggested three levels of influence possibly exerted by the top-level political appointees, (i) constrained and limited, (ii) mid-extent, (iii) greatly influential and forging (1999). The first class would be represented in 
the organizational process model of Allison in which he argued that the large scale political and institutional forces often be overwhelming and irresistible in terms of organizational process. The second level was alleged in the similar view of structure that the agencies head often would be slim to be limited to the menu of routines supplied by mid and lower level of managers. Hence, the bureau dominance thought could prevail in this kind of understanding. In this view, we also come to support that the RPO, for example, would be significant, but perfunctory or merely symbolic.

\section{The Degree of the Heads Role in the Rulemaking}

We return to the question of idealistic degree of the heads role in the rulemaking. In other words, how much extent he or she should involve to influence the rulemaking. As a threshold issue, we need to define the agencies head. The senior careerists in the bureaucracy are generally not assumed as the top officer of agencies, instead, political appointees from the new president would generally orient or determine the fundamental direction or policy objective of that specific agency. That would be a due consequence from the spoils system in the United States (Brito, J. \& De Rugy, V., 2009). Hence, we need to consider a specific context of agencies to inquire who actually would be in the position of top decision making. This aspect also raises an oxymoron or myriad of practical variances in terms of the organizational culture and time element. For example, the period in transitions between two administrations would not be seen as same to the mid-period of presidential tenure. The midnight regulation would be characteristic that the political heads would dump the rules or be inconsistent with the continued attitude of prudence. Hence, their role would be intensified on one hand, but would be slim in terms of accountability or reliability. This militates against the public trust and can be countervailed by the new administration, which means the degree of their influence would shrink. This chaos would give us a good experimental lesson in ways about defining the administrative agencies as a fourth branch; their insularity, autonomy, as well as intact continuance as a sanctuary of distinct resources, authority, competence, tradition, network, structure and classification as unimpeded from the shift of government. This point of twilight would undergird new intellectual lens between the political science and public administration. Kaufmann would be reflexive of underperformance of the political scientists who fail to penetrate the essences or elements of new powerful and persistent regime of public administration (Kauffman, H., 2008). The ambiguities and oversimplification from the political scientists about this subject would be a fallacy that failed to monitor the realities and contemporary trends of American bureaucracy. For example, the political appointees now are well educated, and often begin their career in the public administration (2008). They would remain an important or significant position as a top officer even after their political host would cease and hand off his administration to a new president (Brito, J. \& De Rugy, V., 2009). Therefore, the traditional distinction between the political appointees and career-based bureaucracies would well be blurred, which would, however, be overlooked in the literature of political science (Kauffman, H., 2008). They tend gradually to turn affected from the objective merit or national interests than a political priority. They would also share the experience, know-hows, expertise as well as professionalism as a careerist beyond the paradigm of political servant. The structural concern of political scientists on the checks and balances would be fused into a smack of bureaucratic professionalism. In this case, the role of agencies head should influence any more significantly on the rulemaking process. 
In short, understanding the influence of agencies head would depend on the factors involved and circumstances present. As a matter of settled practice over history and tradition, the political appointees would serve to represent the popular will based on the spoils system. Their influence would not be assessed in any one way, but generally influential at a big scale, which would complement with the resilience and many ideals of public administration, such as certainty, concept of vested rights, consistency and predictability. The role of agencies would exceed that of heads in this respect. Nonetheless, the most senior careerists often would not be a head, which could only be enabled in the powerful seniority system of government. If we linger on the thought of inherent contradiction as involved in the judicial independence and political primacy, the seniority system would be posited as a moderate form of conflict between the democratic representation and civic virtues. Practically, however, the political appointees would no longer be a distinct politician, who gradually shares the administrative values. The degree of influence on the part of agencies' head would be viewed in consideration of such factors and context discussed thus far.

\section{Reference}

Brito, J. \& De Rugy, V. (2009). Midnight regulations and regulatory review. Administrative Law Review, 61(1), 163-197.

Kauffman, H. (2008). Ruminations on the study of American public bureaucracies. The American Review of Public Administration, 38(3), 256-263.

Kaufman, M. (2005, Oct. 14). Ex-FDA chief would not aid Plan B inquiry; Final edition. The Washington Post, A.05.

Kerwin, C. M., Furlong, S.R., (2011). Rulemaking: How government agencies write law and make policy (4th ed.). Washington, DC: CQ Press.

Hammond, T. H. \& Knott, J. H. (1999). Political institutions, public management, and policy choice. Journal of Public Administration Research \& Theory, 9(1), 33-85

Sapien, J. (2008, November 11). Will Bush’s midnight rules be reversible? Retrieved from http://www.politico.com/news/stories/1108/15758.html

Sapien, J. \& Nankin, J. (2008, November 18). Midnight regulations. Retrieved from http://www.propublica.org/special/midnight-regulations 


\section{A Case and Justiceability}

\section{Massachusetts, the Parties, and Court Views}

In the Massachusetts v. EPA, several states challenged that EPA is required to make a rule to regulate the greenhouse gas emission standard for the new motor vehicles (Harrington, C. B. \& Carter, L. H., 2009; O’Leary R., 1993). It would fall within the responsibility of agent who has to consider prudently the scope and exact nature of congressional authorization and generally in terms of APA provisions or principles as well as the specific statute enabling their rulemaking power. The plain language rule often would be emphasized in any intensity by the Court so that this case poses the question how to cognize the term "air pollution." The state of Massachusetts claimed that they are a guardian of their citizens' property interest of coastal land, hence, parenspatriae, to invoke a federal jurisdiction and in the purpose to redress from the inaction of EPA $(2009 ; 1993)$. It argued that the inaction of EPA failed to adequately respond with the climate change and its fatal consequence of sea rising. It eventually eclipses a serious amount coastal part of land although the present damage would be a piecemeal and not readily discernible. The Court granted the standing as constitutional on the ground that the "special solitude" needs to be contemplated from other class of parties, such as private enterprises or civil pressure group. A quasi-sovereignty to protect the public health or general welfare of state citizens deserves a special context of treatment in finding the constitutional basis to legitimate their claim. The Court also illuminates on the component of traditional frame which dealt with the injury in fact, causation, and availability of remedies (2009). The Court found in the affirmative and rejected the list of declarations which were filed to support the EPA's inaction decision. The injury in fact often requires concrete harms or loss of legal rights and interests. An imminent danger or impending harm could suffice in the general purview but a particularized status has to be identified which means a loss or harm generally shared by or incurred against the public at large would not qualify to ground the competent jurisdiction. While the research and administrative assessment would ascribe it as remote in terms of the time and pattern of harm, the Court would consider the evils of inaction more seriously in balance with the scale of losses or damage for the citizens of Massachusetts. The causation may not posit a definite framework, which is to be frequently faced with in other actions. It would not be generally disputed that the greenhouse gas emission is a primary contributor to the climate change and global warming. The global warming, in turn, should be found in a decisive correlative with the sea rising level, which merits a rejection of EPA's contention (2009; 1993). EPA also raises the multiplicity of factors which leads to a blurred line between the international emission, notably China and India and national one. In this peculiar situation, the imprudent response would not be adequate as a national policy maker. The context may go international beyond the control of national agencies, which would be attributable as Nature or force majeure to make it wise on the status quo. The Court also denied this argument because the national emission is sufficient to be captured as one important culprit of this territorial disfiguration. The US part amounts to 6 percent of total global emissions only outpaced by the EU and China, which ranks the nation at the third place (2009). Then the Court saw that the EPA overstated their case. EPA also contended that their inaction would be appropriate to progress on the concerted response in the initiative of president. It would plan to enforce a scope of effective programs involving a grant and financial incentives, which would be comprehensive to ensure an organizational integrity and comport within the Executive (Johnson, S.M., 2008). This assertion was fleshed out by the dissenting opinion to critique the 
majority opinion, but the Court would rather conceived it a piecemeal or less consequential since the specific regulatory measure instantly or immediately embodied and also specifically would be more practical.

\section{Revisiting the Justiceability}

We may now be poised to conduct ruminations why the Court would elaborate on the question of reviewability. I may propose several points from the practice of justice, which is thought to bear implications. A reviewability or justiceability for some, is a threshold issue to enter the adjudicatory phase of subject matter so that it involves a structural issue among the tripartite branches of government (Woolf, L. \& Jowell, J., 1995).

A justiceability would originate theoretically from the earlier espousing of legal philosophers and realized in the scheme of US constitutional rule. It was implanted for reasons and to organize the federal union as we affirm in a number of federalist papers, which responds with the need to construct any altered paradigm, what we now call the modern constitutionalism (1995). The Constitution is a unique source of governmental power in contrast with the divinity of monarch or Catholic supremacy until our inauguration in the new lands. Although the federal supremacy was elicited in express language, the hierarchy of norm failed to be defined explicitly. The higher law concept, as expounded by Sir. Blackstone, would be resilient to impact the case, Marbury v. Madison, which has continued to be argued by the scholarly circle about its anti-majoritarian difficulty (1995). The separation of powers principle perhaps would be assured most practically by the judicial branch so that we may not falter if to ascribe them as a bulwark of the federalism and constitutionalism. Hence, a selfreflection or definitional work would be pivotal if we exercise the dimension of ultimate authority at the top of Constitution. Some presidents would argue on the autonomy of respective branch about the constitutional interpretation while others would be generous or favorable to interact with the judicial organ. The self-restraint or political question doctrine discloses the inextricable constraints of which the judiciary could not be derogatory. The case or controversy requirement had been ordained and the original jurisdiction was pronounced to define the essences of judicial power (1995). It would be an inviolable mandate of constitutionalism that the judicial branch exerts to maintain the national integrity and system. It would be an idealistic organ to afford the virtue of human rights given it is specific and enforceable to create a distributive justice and in terms of the Plato's. Nonetheless, its power is conditioned on the constitutional theory and terms to be shared for a uniform national response and plurality of interests, but should be checked and balanced to respond with the universal virtues of human right. The human rights would be an ultimate destination toward which the scholarly and governmental goals or direction would be steered. The complicacies of reviewability would be waged in this framework. In sum, the first point underlies within the theoretical and constitutional mandate whether to grant a reviewability or not. The agencies share this concern to procure a workable government with respect to the constitutional structure and authority, who would be an indispensable party of administrative law cases.

The second point involves the public policy making role of judicial branch in collaboration with the agencies. Both organs would impose a separate level of administrative rules or extent of implementation in consideration of cost and benefit analysis or fiscal capabilities of government. The activism of Court and bureaucratic practices would facilitate the general welfare or public health of citizenry. It, nonetheless, requires a costly response and expensive institutions that have to be weighed so as to determine the legality of 
administrative action or inaction. For example, a regulation to prevent some level of greenhouse gas emission would reduce the air pollution, but could compel the costly resources to enforce the rule. The statutory language and goals, legislative intent and history as well as other many factors would be evaluated in the balancing test and to define the proper scope of agencies' responsibility.

The third point would be concerned of brother branches' role or interplay in terms of judicial oversight and administrative autonomy or insularity (Kerwin, C. M. \& Furlong, S.R., 2011;Shapiro, S. A., \& Levy, R. E., 1995).The check and balance scheme of Constitution necessitates the judicial review of administrative action or inaction in which the Court would entertain a final say about the destiny of public programs or judicial standard to be respected by the agencies. However, the judicial branch would be constrained by the Constitution and congressional acts, which are considered as the political expression of nation. The ground rules impose a limitation and the scope of review should be neither arbitrary nor extensive. As the rule of law ideals would govern, the judicial branch has to be placed as central to sustain the civil virtue. The intricate system of federal union and constitutional case laws would certainly be consequential to make the US distinct from other modern democracies. An increased profile of judicial branch in this respect tends to fuel producing a web of constitutional theories and laws, which pertains to their oversight role of agencies. Besides the standing requirement, they invented an important concept, what we term as zone of interest, if to grant or deny a reviewability. In the Data Processing, the majority court applied this theory, and granted the plaintiff's standing who claimed the agencies' action on the Bank Service Corporation Act (Harrington, C. B. \& Carter, L. H., 2009). The majority court ruled that there is no presumption against the judicial review and in favor of administrative absolutism. In the Abbot Laboratories, Inc, the Court found affirmatively that the ripeness doctrine supported the case as eligible for judicial resolution (2009). It also addressed the issue of whether it met the requirement of "final agency action" within the meaning of statutory language set forth in the Art. 702 of APA. Actually the FDA did not complete a rulemaking in which phase the regulation would not enter any legal force. This status, therefore, could not bring any concrete harm or loss, for example, imposition of criminal penalties or other administrative sanction. It would, nonetheless, imminent or impending, and the prospect that the agencies would be coercive civilly, if not criminally, to pose an immediate threat to their legal interests. The judicial review would be permissible in this situation.

Fourth, the point of consideration would involve a citizen initiation or democratic monitor of the governmental process, which often would impose the ingenious context of lawsuits uncharted in the last liberal framework of litigation. For example, the taxpayers would consolidate to challenge the agency action or inaction, and non-for profit organizations of public nature, such as the environmental groups or association of fair representation would actively engage to seek a social justice in the judicial confines (1995). This contributes to the increasing intensity of judicial deliberation whether it conforms to the embedded concept of justice administration, such as adversarial proceedings, ripeness or causation and redressibility. The "zone of interest" principle also comes in that standpoint of view. The Court would deny or grant a reviewability over a scope of public suits in that perspective and theories as we confirm in the Sierra v. Morton, Bennet v. Spear, Lujan v. Defenders of Wildlife and so on (2009;Federal Administrative Law, 2014;O’Leary R., 1993). However, an individual may pursue to restore their private interests as in the case of Defunnis. In that case, Defunnis was finally conferred a law degree in the Univ. of Washington Law School which actually rendered it moot his case of discriminatory admission decision by the state agency 
(2009).

\section{One Insight from the Judicial Practice}

In a plethora of factors or variables, the pervasive mental gears from the judicial practice tend not to neglect on the classic concept and notion, to say, their crucial commitment to safeguard the property rights and inter-branch solitude and mutual respect of insularity and autonomy. In the Massachusetts, the suit bears a resemblance with the challenge of environmental claim, but survived in terms of reviewability provided that the claim eventually asserts the loss of property interests for the coastal land, not merely the degradation of environmental quality. The land ownership is traditional and possesses any retrenched quality of proprietary interest since the feudal times which would not be compatible with the loss of decent lives or mental distress. It would be concrete and well based to claim invoking a judicial intervention. In the Laidlaw Environmental Services, the Court ruling additionally showed the preliminary measure of administrative sanction or settlement effective to afford the agencies' response as viable, and should not be tainted by the judicial intervention. The administrative techniques, for example, civil penalties and reform settlement, would fall within the exclusive preserve of agencies and to increase a regulatee's compliance (Kerwin, C. M. \& Furlong, S.R.,2011). The Court would be courteous to deny the action of environmental group, which would go deferential and respectful to the option of agencies. In that case, the plaintiff, environmental group titled the Friends of the Earth and in association with other civil groups, sued the Laidlaw Environmental Services who purchased the wastewater treatment facilities and allegedly violated the limit of toxic pollutants into the waterway of North Tyger river. The DHEC (Department of Health and the Environment) of South Carolina granted a permission to leak the mercury and legalized the facilities according to the Clean Water Act. The plaintiffs argued that the defendant had a track record of river pollution from 1987 through 1995 about 495 incidents. The environmental groups gave a notice that it initiated an injunctive relief upon a lapse of 60 days from the date of notice. The defendant petitioned that the DHEC immediately would respond with the administrative suit. In the proceeding, the defendant and DHEC reached the contract settlement about the civil penalties, 100,000 dollars, and to refine the facilities to comply with the permission of mercury leakage. The environmental groups did not consider that the state government diligently implemented the administrative remedies, and brought a controversy to the federal court. The trial court denied their claim and the appellate court affirmed. Pending the Supreme Court, the case went moot that the defendant business turned to be closed down.

\section{Judicial Review and Some Structural Thought}

The Judicial Review is an institution in which we contested the national policy and public good. Typically, it would be a forum enabling that the abstract nature of public standard and political expression were converted in any definite way about the public lives. Hence we would recognize in dual virtues. On one hand, it would function to protect the insular and discrete minorities. On the other, it formulates a judge-made law to give a standard and complements with the general direction and intent of political branches. It would be a useful classroom that the policy administrators could be inculcated to steer and practice their commitment. For its intrinsic and attributes, the court could be a more effective agent. They could be more concrete and practical with the material presence of issues and disputes. While the political branches could exploit the science and expert information, the judiciary could be aided, in addition to the expert testimony and any available evidence, with 
the presence of aggrieved humans and specific situation or context to materialize an issue or contention. They could not only meditate on the fiscal capabilities of nation, but also an impact from the agencies' inaction through the terminal policy addresses, such as the proprietary people of the coastal land in Massachusetts (Harrington, C. B. \& Carter, L. H., 2009). Provided if the statutes and congressional acts are not crystal clear and often pose a leeway of interpretive possibilities, the judicial process and interactive lesson among two agents consequentially would develop a general merit to create the standard of practice for the public agents. As Ackerman illuminated, the Court would be a least dangerous branch which could deliberate the constitutional issues and basic national policy. They are generally insulated from the political influence and afforded with a plenty of leisure time to think about the controversies in a scholarly way. Beyond it, the judicial style of Court is distinct among three coordinate branches where they even do not mind to become a storyteller with facts and sociological ways of deliberation to assess the impact of their decision within the society. A wisdom from the separation of powers principle, nonetheless, delimits the constitutional structure of government and authority. The principle could be shed in light of the human rights which could, for example, work to prevent the kind of judicial tyranny, such as the Star Chamber in the medieval monarchy and legislative derogation in the colonial period. As for its importance as a threshold issue, the standing requirement is dealt not only importantly but also scrupulously over the cases. The tendency of Court may not be consistent, however. The Court in some cases, may prefer as less as a gate keeping role, and in other cases, may be generous to be deeply involved in the subject matters (2009). As the workload of Courts is never impractical, the kind of certiorari system would also militate against the more comprehensive role of Courts as a policy maker. It would, in any way, be not deniable that this area of cases or controversies would more extensively face with the challenges of standing (Shapiro, S. A., \& Levy, R. E., 1995; Woolf, L. \& Jowell, J. (1995).

\section{The Standing Requirement}

We can ascertain two possible attitudes or tenets where the standard could be shaped. One would be a private law model. The leading advocacy in this stream may be found in many opinions of Justice Scalia. The other views would support a public law model which would most notably be argued by Fletcher. The private model espouses the view that a justiceability could only be granted in cases where the personal rights and interests are harmed or damaged. The scope of them would include the property, contract, tort and statutorily conferred privilege. This theory focuses on the contractual framework of modern democracies so that the public intervention has to be minimized upon the voluntary consent of regulatee's (Kerwin, C. M. \& Furlong, S.R., 2011). The common law of property and contractual rights would determine their extent free from the state and other persons. The public interest would ebb in this view, but the least necessary regulation falls within the responsibility of administrative agency. This framework would retain a persuasion in response with the administrative state and professionalism of public administration. The judicial review, in this social aura, would set back from the active oversight of administrative agencies, and largely defer to the expertise or autonomy of them. Justice Scalia argued in his article published in 1983, who pointed to the constitutional role of judiciary (Harrington, C. B. \& Carter, L. H., 2009). He founded on the Art. III Sec. 2 of Constitution, which should be churned to respect the separation of powers principle in caution of possible overjudicialization. The Court would class two grounds as differs in its meaning about the justiceability, which is constitutional and prudential. The constitutional element should not be impaired absolutely whereas the prudential strands may be malleable to the wisdom of Court 
and Congress. For example, imagine that other person built a gas station in violation with the urban planning statutes. It would entirely depend on the Congress or Courts whether he directly sues for the violation or the agencies could only be competent to implement for cure of such violation. In contrast, the personal injury in fact would be constitutional that could not be transgressed either by Congress or Judiciary itself. The problem then turns to how to define the personal rights, interests and privileges, which have grown conceptually. Nowadays, the environmental interest or aesthetic value would be cognized by the judiciary. The APA 702 (a) can be construed to incorporate this perspective as stated "any person suffering from legal wrong... adversely affected or aggrieved by such action...”

The public law model puts an emphasis on the oversight role and effective control of agencies by the judiciary, who arguably lost their status as an authority on the public representation (Kerwin, C. M. \& Furlong, S.R., 2011). Provided if, as a consequence, the Constitution and congressional acts authorize a cause of action for the public interest, the Court could adjudicate regardless of the impairment of personal rights. The view, therefore, generally considers the Court as an ultimate watchdog of public policies. Given a clear basis of statutory cause of action, the standing could not forestall the judicial process whether or not the persons and groups incur any concrete loss or harm discernible from the traditional notion of personal interest. The public law model would expect the Congress to act like the private attorney general, who can shape the scope of standing on their own value assessment. It has a historical trace in the informant suit or qui tan actions in the British and earlier US laws. Prof. Fletcher counters that, the injury in fact, though asserted as polar in the polemics of private model, would not serve the separation of powers principle. The advocates of private model would view that the word, "in fact" would comfort an independent basis for the judicial authority. Nonetheless, it overlooked that the judicial speculation eventually comes to involve a normative dealing to see whether the rights or interests could be ascertained in terms of common law. The APA 702 (a) can support this view, “...within the meaning of any relevant statute." One excellent example would be Geraghty where he filed a class action to challenge the federal parole regulation with his inmates. Pending that action, he was set free, but the Supreme Court could continue to complete his action to decide if the regulation could be sustainable since his cause is public, beyond his private interest, This status is conspicuous since he represents their class interest legitimated in the Federal Rules of Civil Procedure. The public model also illustrates the rule of advisory opinion, one theoretical support for the private model, and elicited that it is not necessarily governing from the historical and practical rationale.

\section{The Laidlaw and Its Implications}

As previously, I have introduced the Laidlaw in terms of administrative insularity and autonomy about the enforcement technique, say, civil penalties (Kerwin, C. M. \& Furlong, S.R., 2011). The Laidlaw Court generally can be considered as activism of judiciary, which would be one of co-equal branches to collaborate and to forge the administrative goals. It shares the effective role of civil penalties to attain a public goal. The Court, on the other, disfavored a traditionally stern review of standing, but applied a relaxed standard on the injury in fact and redressibility. The plaintiffs alleged that the citizen could no longer entertain the North Tyger River from the fear of mercury polluted waterways. They no longer wished to purchase the adjacent land parcels. The defendant argued in countering that no evidence supported a level of pollution to harm the public health, and the fact alone could not meet the traditional injury in fact test. The Supreme Court opined that a discontinuance to 
entertain the river and in use for a repose and recreation could simply verify a decrease of its aesthetic and recreational value. The fact presented for the court review would suffice to find the injury in fact was incurred. The attitude of Court seems to change a little from the previous rulings, such as Lujan v. Defenders of Wildlife. In Lujan, the Court rejected the argument on the ground that the injury in fact could not be established or that causation was so remote (O’Leary R., 1993). In that case, two members of environmental group asserted that the US aid to the foreign nations would foster an exploitation of natural resources and that they would lose the chance of fantastic eyesight for the rare species and animals. The Laidlaw rule likely applied to Akins where the Court respected the statutory scheme of FECA to specify the extent of concrete injury. Upon the denial of petition to request a public disclosure of campaign fund raising record, the civic group filed a suit and the Court granted a standing (Harrington, C. B. \& Carter, L. H., 2009). This implies the Court would turn to see more favorably the public law model. Before the Landlaw, the federal courts continued to deny a redressibility in the case where the civil penalties were to be sought. It does not consider it as one of private remedies for the persons or groups. In the Steel Co., the Court emphasized that the violation has already ceased, and the civil penalties would be destined to the account of Treasury Department. The framework has shifted to follow the public law model in Laidlaw that the civil penalties sought as a final remedy by the plaintiffs was viewed to effect on the higher compliance of industries. It could fit within the purview of redressibility, and the standing could be granted. The Laidlaw case would impact significantly to enlarge a judicial intervention through the civil penalties on the selected public statutes. A scope as permissible to pursue the administrative responsibility was confined to the injunctive relief only. A reformulation of the legislative and judicial policy over the cases would transform toward some of collaborative shape on the paradigm of public law model. On the other, we can note that the lower courts of Laidlaw uphold the traditional division between the private remedies and enforcement sanctions or techniques.

\section{Reference}

Harrington, C. B. \& Carter, L. H. (2009). Administrative law and politics: Cases and comments (4th ed.). Washington, DC: CQ Press.

Kerwin, C. M. \& Furlong, S.R., (2011). Rulemaking: How government agencies write law and make policy (4th ed.). Washington, DC: CQ Press.

O’Leary R. (1993). Environmental Change: Federal Courts and the EPA, Philadelphia. PA: Temple University Press.

Shapiro, S. A., \& Levy, R. E., (1995, April). Judicial incentives and indeterminacy in substantive review of administrative decisions. Duke Law Journal, 44(6), 1051-1080.

Woolf, L. \& Jowell, J. (1995). Judicial Review of Administrative Action, New York. NY: Thomson Professional Pub Cn. 


\section{Judicial Review and Inter-Branch Conflict}

\section{An Introducing Thought}

A conflict between the Congress and Executive would arise for reasons. A most important reason would lie within the structure of government (Samuels, D. J. \& Shugart, M. S., 2003). The parliamentary system of government would share a political destiny by both branches where one general election would take a whole of stake to alter the congress and cabinet. The head of winning party would be nominated and eventually elected almost all cases to serve as a prime minister and leader of congress. Often the monarch would approve to finalize his inauguration though symbolic and nominal. The communist legal tradition, as we see in the former Soviet Union, would generally never permit a conflict between the executive and people's congress since the communist party would control absolutely every of state affairs. The key public policies and important decision making would be prepared by the selected communist elites in advance before a convocation of people's congress. The congressional convention merely makes it official and showcased without a due process of deliberation and free vote. They generally play a puppet role to endorse the prearranged agenda and ready-made directions, goals and decisions. In these two cases, the legislative sovereignty, as a matter of national distribution of power and except for the communist supremacy as quasi-religious in the latter case, generically preempts the executive function that the interbranch conflict would not be present as a matter of structure and authority. Then the topic dealt in this week would be in most probabilities interconnected with the presidential system and the types of constitution employing the separation of powers principle (Kirwan, K. A., 1995). In this class, however, the neo-presidentialism should be revisited, which prevailed within the dictatorship of new born republics since the end of world war and later over 1950 to 1960's. This type of governmental structure would not be committed to the liberal democracy or check and balance scheme in order to prevent an arbitrary rule and for the safeguard of human rights. The President would entertain a prerogative as comparable with the divine monarch (Lobel, J., 2008). They may lead the congress in hierarchy and spiritually while he staffed a portion of congressional seats in some cases, as in the 1970's Korean constitution. The conflict, if rare and exceptional, could occur, but not in any institutional fashion, but on the street demonstration or political struggle on the grass-root and in terms of civic priority or urgency. Given a scarce source of conflict, the judicial role to resolve it would not be eminent in nature, instead, as minimal or perfunctory. For example, over the two decades of constitutionalism in South Korea in the period of 1970's and 1980's, the supreme court would undertake as less than ten cases of judicial review of legislation. Therefore, we can arrive that the conflict of two political branches and the judicial role often would be predicated on the orthodoxy of presidential system, stringent tripartite government, as well as an independent and neutral judiciary as civilized. One other element has to be added that the constitution is a Grundnorm to be principled and structural lacking the minutes and details. It could include ambiguities and an extent of amenability to some diverse interpretive possibilities (King, K. L. \& Meernik, J., 1999). That would be demonstrated in the cases of presidential immunities or privileges, foreign policy and national war response. The constitutional language often would not be definite as the Johns, Nixon, Fritzerald, Starr, and Youngstown cases evinced (Amar, A. R., 1999; Pettee, J. S., 1998).

\section{The Youngstown Steel Case}


In the Youngstown case, the Court was called upon the question how to define the limits and exceptions of emergency power not expressly vested within the Executive. The case arose in the war situation of two Koreas in 1950, and President Truman ordered to seize the assets and properties of steel companies to effectively respond with the war emergency. Unlike the new shape of numerous modern constitutions as exemplified in the current Korea's, the classic constitution has not lent an independent place for the emergency power of president. The executive order in this case involves a serious issue of property rights which would be classic and foundational as we learn in the plutocracy view. The founders of new republic in this continent would deal with the popular democracy or social contract theory in any less practical effect, but treated as merely idealistic. Intricacies and wisdom were poured to ensure a delicate and mosaic of system for the check and balance scheme, as illustrated in the bicameralism and tripartite branches. Such high brows would anticipate a sacred role of judiciary to ensure their property and commercial interests. Their distrust of politics and general people perhaps should be traumatic, hence, intended on a scheme to shackle any one branch dominance between the congress and executive. The conflict, nonetheless, would never be their wishes given the basic needs and commitment of national government could not be dispensed away (Conkle, D. O., 1998). This leads to necessities of prudent process to touch on the property interests and freedom of contract, which could only be framed or implemented on the basis of congressional act. This theme was broken in face with the war emergencies of South Korea, which had been contested in the judicial terms. The judiciary would be called to define the scope of war power as a president and additionally as a commander in chief, and should never intermeddle a crucial class of authority and power to respond with the war needs.

The Government argued that the order was made on findings of the President that his action was necessary to avert a national catastrophic which would inevitably result from a stoppage of steel production, and that in meeting this grave emergency the President was acting within the aggregate of his constitutional powers as the Nation's Chief Executive and the Commander in Chief of the armed Forces of the United states (Devins, N. \& Fisher, L., 2002). In fact, the union would struggle with their employers over the terms and conditions that should be included in new collective bargaining agreements. Long-continued conferences failed to resolve the dispute. The mill owners argued that the presidential order amounts to a lawmaking, a legislative function which the Constitution expressly confided with the congress, not to the president (2002). The Government furthered that the indispensability of steel as a component of substantially all weapons and other war materials led the President to believe that the proposed work stoppage would immediately jeopardize our national defense and that the governmental seizure of the steel mills was necessary in order to assure the continued availability of steel (2002).

Justice Black, for the majority court, delivered the Court opinion. First, The President's power, if any, to issue the order must stem from either from an act of Congress or from the Constitution itself (2002). There is no statute that expressly authorizes the President to take possession of property as he did here. Second, the use of the seizure technique to solve labor disputes in order to prevent work stoppages was not only unauthorized by any congressional enactment; prior to this controversy, Congress had refused to adopt that method of settling labor disputes. Third, the order cannot properly be sustained as an exercise of the President's military power as Commander in Chief of the Armed Forces. Fourth, the seizure order cannot be sustained because of several provisions that grant executive power to the President (2002). Fifth, the President's order does not direct that a congressional policy be executed in a manner prescribed by Congress-it directs that a presidential policy be executed 
in a manner prescribed by the President. Sixth, The Founders of this Nation entrusted the lawmaking power the Congress alone in both good and bad times (2002).

\section{The Theme of Constitution and Structural Thought}

The court would be designed to play a role to resolve the conflict between the Congress and Executive. The Constitution must certainly an enabling document to frame the civil and liberal democracy on which the public and private values would be contested, but generally in terms of structure and authority (Harrington, C. B. \& Carter, L. H., 2009). In other words, its primary role would underlie creating of foundational order for the structure and function of government. The main text of seven articles was to be devoted to the necessities in the newly born independent republic. The bill of rights would follow to deal with the new paradigm of human and philosophically indispensable values, but in the form of amendments. Now the people would be an essential ingredient with the surge of popular sovereignty for the replacement of divine monarch. They must be supreme and ultimate destination to be idealized on one hand as we see a corner of Constitution, "We the people...,"”'heavenly bestowed...inalienable fundamental rights, "life and limb, and liberty..." "to promote the general welfare and happiness...." In other dimension, they are subjects to be ruled by the government and must respect the laws and national policy, but in the check and balance from the separation of powers principle. Most notably, they could be criminally penalized or administratively regulated to comply with. In the cases, we see two cases in some mediate status. A proposition in the Johns case, "nobody would be beyond the law," would then be predicated on a delicate basis that Clinton never acted as a ruler, but privately (Pettee, J. S., 1998). Johns would not represent politically the popular will since it is hyped and merely a collective identity to idealize the constitutionalism, but can be traced in places of Constitution. She is nonetheless not to be put to the context of subjects for the attribute of Clinton's action. Otherwise, the Fitzerald would be predicated on the official conduct of Nixon, but not related with the rule and ruled concept, but for their internal matters (1998). Nixon would not rule, but order and command to attain his goals of branch. Therefore, the court resolution would get less straight for all of two cases. One case is considered to generally deny the absolute presidential privilege in the civil actions, but the President merely paid the damages with a generous comment and no forcible court order to subpoena or make him present. The Fitzerald court also was split to grant the reversal of his dismissal as a civil servant. In the main, the Constitution is a resort place, perhaps however any most authoritative and resilient over history and comparable to a counterpart on the Marxist theory on Capital, that we awe and incessantly legitimate our public action to interact with the civil society. Actually, the structural dilemma and ambiguities as unspecified from the constitutional language also arouse a rather complicated vision, under which three branches would involve an enthusiasm to increase or a defense for their constitutional powers and responsibility (Harrington, C. B. \& Carter, L. H., 2009).

\section{The Characteristics of Constitutionalism}

We can elicit several points to note basically. First, the Constitution is qualified to govern public issues, hence, conceptually classed as public law. This means that the law receiver will be a public agent, including three separate branches if broadly. This classic document would not be a norm to directly touch on the civil matters, albeit indirectly concerned, for example, of federal jurisdiction about diversity. The state action theory was 
designed to lift this deep curtain in order to expand the constitutional value for the powerful actors of society and as non-state. Second, the Constitution has to found a power distribution since the King would be dead to surrender to the civil power (Kirwan, K. A.,1995). We can likely take an inside look into the intrinsic of King's power, which however, should be dissected to derail a very probability of arbitrariness of humanity. The Founders further advanced to the distrust of politics beyond the human availability of evils with the ambit to divide and rule. Only the Constitution, generally abstract and publicly notorious and objective, could be final for the public matters (Harrington, C. B. \& Carter, L. H., 2009). This would be never thought to be any lengthier. Nonetheless, it would be a center of contest for the national politics and community about the centuries enduring. The tripartite branches then could be assigned from this monstrous and hypothetical King about its space, yet never be perfect to rule, but partial to collaborate and check to balance. A theme of "workable government" would be reflexive, perhaps, of the former. The Chadha court's words, "all the cost could be gladly borne despite its untidiness, delay and possible flaws...” perhaps would be a judicial conviction to curb the legislative or executive despotism (2009). The criticism from Southmay also would highly tilt on the latter ideals if he eagerly attributed the Court in US v. Nixon that it eventually brought the consequence which trivialize the Executive, imperialize the judiciary and marginalize the legislature. This never connotes an encouraging experiment from R. Dworkin on his treatise, "Empire of Law," whilst critiquing the judiciary intruded a necessary and proper space for the unique office in the nation. His argument advocated from a failed balance among three branches for the high time of pro-presidentialism (Amar, A. R., 1999). The context could be highlighted in any sharp contrast if we get to face with the testimony of St. Clair, Nixon's attorney, “The President wants me to argue that he is as powerful a monarch as Louis XIV, only four years at a time, and is not subject to the process of nay court in the land except the court of impeachment.” Nixon was finally condemned to be divested of arguably must-be safeguarded privileges or immunities. The areas could well be said as peculiar and chaotic since the war situation and foreign policy would be less definite to make it in any fine normative frame (King, K. L. \& Meernik, J., 1999). The tendency corroborated over history under which circumstances the President generally pursued a higher extent of prerogative. A Vietnam war for Nixon, Truman administration in Youngstown, Roosevelt in the World War II and G. Bush in Iraq would be adequate so as to be embroiled with such controversy or public criticism from the normative challenge (Conkle, D. O., 1998). Perhaps Roosevelt might get not so audacious to transform the national paradigm for the ethos of social justice unless he was situated in any turbulence or emergency between the atrocities of two Wars. The views might not be false if G. Bush would properly be subjected as the kind of modern monarch if to be sensible with the new term "political justice" or "national administrators" Third, the level playing field would be delicate in dualism as stated, so that the grassroots of civil society would not collapse, which we would be resilient to evolve for the interactive dynamism. There would be no definite say about what the Constitution speaks about. The views of strong presidency and weak one could be framed to make it perceptive of the difficulties about the constitutionalism. The presidents in some cases may not readily surrender to the judicial rule-making on the basis that he or she would be an independent authority to make it constitutional. Generally, the Congress is an essential branch to interpret the Constitution since they enact the laws under the ideals and goals of Constitution (Harrington, C. B. \& Carter, L. H., 2009). It also is generally uncontested that they are politically accountable to oversee the Executive branch, which must be, and can be entertained as grounded on the Constitution. The part of Executive would be more difficult when we attempt to gauge its proximities with the Constitution. A first priority 
of theirs would be to execute the laws, in which case, however, the laws often would be a public statute and their own rules. No focus could be imagined readily if they must be constitutionally sensitive. The practical chances would but be high if the litigation would arise from their implementation where we can note the kind of judicial dealings, “....rendered void on its face.....or as applied.” They may be brought to respond with the challenges to make their rules or programs discarded, which may alarm to redirect their work commitment. Prudent bureaucrats may maturate themselves with the case law in their specific expertise. Beyond this, we would hardly flourish with the conflict of two branches in pursuit of the right way of constitutional understanding. The war and foreign policy areas could be on vision and to muddy any definite virtue of constitutionalism (King, K. L. \& Meernik, J., 1999).

\section{A Social Legislation: Weak Form of Conflict and Constrained Power}

The social welfare legislation schemed by Roosevelt in 1930's could be one example that the court attempted to constrain the Presidential initiative and Congressional followers which was counteracted to make it fruitful eventually (Harrington, C. B. \& Carter, L. H.; Samuels, D. J. \& Shugart, M. S., 2003). In that context, the murky nature of floor interaction among the three branches could be defined in terms : (i) strategy and tactics of respective branch and pattern of power struggle (court packing plan) (ii) the dominant ethos and compassion of nation (depression and needs to save the national economy) (iii) intelligence wave and prevalence (surging quest of social justice) (iv) tradition and reform of public structure (classic, but rising profile of administrative government) (v) normative understanding of Constitution (redistribution and regulatory or classic and liberal). This would not be the case of conflict among the political branches, but showcased that even collaborative steps could be constrained.

\section{The Bowsher v. Synar : the Structural Constrains and Judicial Control}

Let me illustrate the Bowsher v. Synar decided in 1986. The question presented by these appeals is whether the assignment by Congress to the Comptroller General of the United States of certain functions under the Balanced Budget and Emergency Deficit Act of 1985 violates the doctrine of separation of powers (Stone, G.R., Seidman, L.M., Sunstein, C.R., Tushnet, M.V., 1991). The Comptroller General is the head of the GAO, and his office was created by the Budget and Accounting Act of 1921, which vested him with the duty, inter alia, of investigating all matters relating to the receipt and disbursement of public funds and of reporting to Congress and President about these matters. Although the Comptroller General is nominated by the President from a list of three individuals recommended by the Speaker of the House of Representatives and the President pro tempore of the Senate, he is removable only at the initiative of Congress (1991). He may be removed by impeachment, or by a joint Resolution of Congress on the basis of permanent disability, inefficiency, neglect of duty, malfeasance, or commission of felony or conduct of involving moral turpitude. The act required that he exercise independent judgment in evaluating the estimates and reduction of spending budget, and that, based on his finding, the President issue a "sequestration order. Congressman Synar brought the action and National Treasury Employees Union. Synar voted against the act, and NTEU claimed that its members were injured because the automatic spending reduction provisions suspended certain cost of living benefit increases (1991). The district court ruled the act as unconstitutional on the ground that the CG exercised executive function under the act-functions that could not constitutionally exercised by an officer 
removable by Congress. Appellants argue (i) that the CG performs his duties independently and is not subservient to Congress (ii) that the duties assigned to the CG in the act are essentially ministerial and mechanical so that their performance does not constitute execution of law in a meaningful sense (1991). The Court ruled that (i) once the appointment has been made and confirmed, the Constitution explicitly provides for removal of officers by Congress only upon impeachment by the House of Representative and conviction by the Senate (ii) Congress cannot reserve for itself the power of removal of an officer charged with the execution of the laws except by impeachment. (iii) to permit an officer controlled by Congress to execute the laws would be, in essence, to permit a congressional veto (iv) it is clear that Congress has consistently viewed the CG as an officer of the Legislative Branch (v) under the statute, the CG must exercise judgment concerning facts that affect the application of the Act. He must also interpret the provisions of the Act to determine precisely what budgetary calculations are required. Decisions of that kind are typically made by officers with executing a statute; (vi) As Chadha makes clear, once Congress makes its choice in enacting legislation, its participation ends (1991).

\section{Reference}

Harrington, C. B. \& Carter, L. H. (2009). Administrative law and politics: Cases and comments (4th ed.). Washington, DC: CQ Press.

Amar, A. R. (1999). Nixon's shadow. (Symposium: United States v Nixon: Presidential power and executive privilege twenty- five years later). Minnesota Law Review, 1405-1420.

Conkle, D. O. (1998). Congressional alternatives in the wake of City of Borne v Flores: The (limited) role of Congress in protecting religious freedom from state and local infringement. University of Arkansas at Little Rock Law Journal, 20, 633.

Devins, N. \& Fisher, L. (2002). The steel seizure case: one of a kind? (Youngstown at fifty: a symposium). (President Trumans’ 1952 seizure of U.S. steel mills). Constitutional Commentary, 19, 63.

King, K. L. \& Meernik, J. (1999). The Supreme Court and the powers of the executive: The adjudication of foreign policy. Political Research Quarterly, 52(4), 801-804.

Kirwan, K. A. (1995). The use and abuse of power: The Supreme Court and separation of powers. The Annals of the American Academy of Political and Social Science, 537(1), 76-84. Available Here.

Lobel, J. (2008). Conflicts between the commander in chief and Congress: Concurrent power over the conduct of war. Ohio State Law Journal, 69, 1-15.

Pettee, J. S. (1998). Clinton v Jones: The Supreme Court refuses to expand the Doctrine of Presidential Immunity to encompass a President's unofficial acts. Journal of Contemporary Law, 24, 206.

Samuels, D. J. \& Shugart, M. S. (2003). Presidentialism, elections and representations. Journal of Theoretical Politics, 15(1), 33-60. 
Stone, G.R., Seidman, L.M., Sunstein, C.R., Tushnet, M.V. (1991). Constitutional Law, Boston. MA: Little Brown and Company. 


\section{Federalism and Federal Supremacy}

\section{Overview}

Federalism generally would underlie within the Supremacy Clause that operates to ensure the integrity and priority of federal power in terms of national administration. The federal power would preempt the state laws and public policy when they come to the same ambit of public governance. Hence the scope of federal power would be derivative, neither exhaustive from the plane, which must be enumerated specifically by the federal constitution (Barnett, R. E. , 2001; Hickok, Jr., E., 1990; Great Neck Publishing, 2009). On the other, the same ambit would be resolved to favor the federal laws and rules in order to ensure the federal union as a polity (Clark, B. R., 2003). The enumerated powers would be set forth in the Constitution, and could be complemented to enlarge via the residue "necessary and proper clause.” An interpretive guide from the court, nonetheless, would not be generous to encompass the scope of public policy area as necessary and proper. For example, the general criminal power would enshrine within the province of state government, and UCC would be a state law for the merchants. Practically, a growing nature of national integration would create the extension of federal purpose which possibly unleashes from the restrictive view of its scope. This could be evidenced as we witness a tack of public laws from the Congress and Federal Register. The Food and Drug administration, EPA, NASA, FEMA, USTR, the Stock and Securities Exchange Commission, FEMA and many other federal agencies may corroborate with this trend. A system of judicial review still may announce the federal acts as unconstitutional on the federalism ground and based on the Supremacy Clause. According to Clark, B.R., a practice of judiciary would tilt on a different treatment between the state and federal laws when it undertakes the constitutional review of challenged statutes or rules (2003). It would be more vigorous to review and invalidate the state laws that conflict with federal statutes. On the other, the constitutionality of federal statutes claimed to violate the Congress's enumerated powers would not be seriously scrutinized. This merely would not be a penchant or attitude of judicial policy, but a view presents the normative and political reasons about this issue. First we could never locate an expressive conferring of judicial power to shape the limits of federal power. Second, the political safeguard of federalism presumes inevitably on the role of states in composition and selection of the central government. The basic frame of Supreme Court on this issue may be found, "under our federal system, the states possess sovereignty concurrent with that of federal government, subject only to limitations imposed by the Supremacy Clause” (2003; Great Neck Publishing. 2009). Clark's argument, on the basis of text, history, and structure of Constitution, the supremacy clause should well be a constraint on federal power. His article discussed the double standard of judicial review in federalism cases, and intended to reassess it in light of the conditional nature of Supremacy Clause (2013). Despite the double standard practice, it would be undeniable that the Constitution would be an ultimate guide to define the scope of federalism (Hickok, Jr., E., 1990). This leads to several assumptions for the federal administrator (i) federal policy should be grounded on the Constitution (ii) the policy area would be deemed significant in the federalism jurisprudence (iii) the intergovernmental collaboration and support would facilitate its commitment.

The Public Education and Federalism in Conflict 
In this discussion, I like to deal with the education sector for the purpose of exploring its dynamism over history, which had been contended or conciliated with the state government and in purview of federalism.

The Founding Fathers envisaged a desired form of public education, which is pivotal to the liberty and autonomous republic in the new land. For example, James Madison held a thought to levy taxes for the public education. Jefferson, on the while, asserted that the role of state or local governments would be any more important for the equal opportunity to public education. They mainly preferred the federal system of public education, but perceived a moderate structure from both sovereignties. They agree on the importance of public knowledge, supervision of schools, and education of school teachers. Nonetheless, the role of federal government should not be extensive, but to get lesser, such as the acquisition of school lands (Ok-yeon Yi., 2013). In contrast, seven colonial states, more than the half of total, had incorporated the education clauses in their state constitution. Furthermore, new states born from the Louisiana Purchase generally ideated the public education into their state constitutions. Therefore, the educational sector would have a characteristic that the state government has long steered any public initiative as complemented from the federal power minimally. In the 1830's eventually, the public education began to take a formal shape from the earlier stringency in public funds. Since the public education was not evangelical at that time, it should suffer from limited provision and operated with some kind of religious understanding. Typically the local governments other than state ones would elaborate on the advancement of public education. The State of Pennsylvania is a first state to enact the school tax laws which overcame a complaint and resistance from the Catholic and farmers of German origin (2013). Against the State senate, it achieved the free public school act in 1834 . Massachusetts followed this precedent, and others would become progenies. Until the breakup of civil war, the state government had been an essential actor to develop and maintain the public education system. In 1862, the federal government enacted the Morill Act which mandated the grant of land, perhaps seen as lesser in view of commitment. The Smith-Hughes Act was prepared to meet the end of vocational training and education, and established an educational facility for the farmers and local residents. The Civil War provoked the public conception of national education, but the state-federal controversy in this policy area simply aggravated. The immigration populace and increasing demand of popular democracy also combined to urge the priority of public education. In 1867, the federal government inaugurated the Federal Department of Education, but relegated in rank merely as the Office of Education until 1930 and under the supervision of Department of Interior (2013). An antipathy and opposition from the state governments against the federal administration of public education would be one reason (Laureate Education, Inc., 2009). An impeachment of President Jackson perhaps would contribute to discredit the federal government. An important moment for the national deals on public education perhaps would be the GI bill of rights in 1944, and the National Defense Education Act for the military personnel. The organic structure also demonstrated that the state government must be a more active player in the public education. The DHEW created in 1953 were divided in two departments for the Human Services and Education respectively. The group of state governments opposed seriously that division policy since the plan could affect an intrusion into the state authority in public education. The expenditure from two departments also confirmed a minimal role of federal government. The educational expense should be as less than five percents of the total budget while the Human Services began at five percents, but rose five times in 2011. The neo-federalism from President Reagan pledged abolishing the Department of Education in 1990's (Okyeon Yi, 2013). As the state is a sovereign as comprehensively reserved with the 
governing power within the Art. 10 unless otherwise provided by the Constitution, it should be a principal actor to respond with the need of public education. A federal involvement could stem from the constitutional ground, specifically the power of purse from the Art. 1, Sect. 8. The people generally agree that the fairness or equal opportunity to public education is important for the social and congruent community, which has been deemed as same with the employment, welfare benefit, medical insurance and housing. The partisan politics also affected a basic direction of educational policy. A piecemeal legislation could be identified, such as the Lanham in 1940 and Smith-Hughes in 1917, in which the federal government administered a fostering role. In response with the Sputnik, President Eisenhower engaged to reshape the math and science education program on the GI Act, which was supported transcending a partisan interest. In the main, however, the role of federal government should be said as still less extended, which narrowed their focus on the deprived class, such as racial or ethnic minority, low income households, and urban poor. The Republic presidents would urge on the role and responsibility of state government, and preferred a result-oriented evaluation in the provision of federal funds. The most eye-opening initiatives could be stepped up through during the Clinton Administration. The PRWORA enacted in 1996 was designed for the technical training and integration of various vocational educations for the welfare beneficiaries (2013). In the basic framework, the role of federal government began to be made clear by the court rules, as in the Serrano v. Priest, San Antonio Independent School District $v$. Rodriguez, Milliken v. Bradley, which expanded the spending aspect of federal engagement for the deprived class. This could be compared with the state role, including the approval of educational institutions, management and degree programs, conditions of degree completion, curriculum and instruction, status and qualification of teachers. A so-called "shirking" could not be cured, nonetheless. We can illustrate notable events and initiatives for the educational welfare federalism, which were undertaken since 1960. From the policy titled "War on Poverty" in the Johnson administration, the ESEA was enacted to empower the federal government to intervene for the public education. On this basis, the Head Start program was launched, which was used to support intensively the disadvantaged children later in the W. Bush administration (2013). The National Teacher Corps has continued on success based on this program. In 1976, Carter administration powered to enact the Protection of Pupil Rights where the NACEDO was commissioned to submit a report to the President and Congress. Under the Reagan administration, the Omnibus Budget Reconciliation Act enacted 1981 was centralized on the budget reduction, which was driven from his promise, "Government is not the solution to our problem, government is the problem." The ECIA enacted in 1981 included the 12 percents of budget reduction for the primary and secondary education, and narrowed an eligibility of educational support for the poor income class. While the Clinton administration pomp up with the Third Way, he promised to reform the federal programs, institutions and policies. The Improving America's Schools Act enacted in 1994 maintains continually the level of grants and financial assistance, but makes it stringent to raise the sense of responsibility for the stakeholders involved. W. Bush enacted the No Child Left Behind Act which shifted the chronic paradigm of "liberal and conservative." His logic and etymology would bethe kind of "ordinate big government" other than "small government," in the least, for the educational sector. In his vision, the federal government may take a preemptive role to transform the American school culture (2013).

\section{The Commerce Clause and Federal Supremacy}




\section{The Nature and Its Understanding}

The Commerce Clause provides that the Congress is constitutionally empowered to regulate the interstate commerce among several states. A prevailing position of Court historically supports a limited view that the etymology of commerce inheres with the gamut "trade and exchange of goods and transportation." Justice Thomas in United States v. Lopez argued that it contradicts with the original intent of drafters, who perceived a gainful activity to be in plot (Barnett, R. E., 2001; Coenen, D.T., 2003). Justice Robert also distinguished in the Obama Care, who excluded a compulsory purchase of health insurance from the commerce power of Congress. He restored the meaning of commerce clause to regulate the market participants who should not place an undue burden on the free flow of interstate commerce. Hence, the frame would be designed to respond with the distorted effect of national commerce, not to increase the burden of private businesses. The structure of claim must be based on the federal tax power to challenge the program. Barnett suggested that the expanded scheme to include a gainful activity should not be supported from aspects of historical evidence, such as the Constitutional Convention, ratification of debates, and federalist papers (2001). His investigation found that a narrow reading has been consistently held through both for the domestic and foreign trade. The clause was intended to regulate how an activity may be transacted. Then the commerce clause provides that the Congress can specify rules in the manner to remove obstructions erected by the states in ill consequence against the interstate and foreign trade. The case above must be one of rare species, say, one in the last sixty years, to strike down the federal act based on the Commerce Clause. Justice Thomas elaborated to criticize the current understanding of Commerce Clause from the originalist position (2001). The most distinct element in etymology is a counter-distinction from productive activities, hence encompassing the kind of notions, buying, selling, bartering, with merchandise, and trade. He also pointed to the views endorsed by the SC of the Progressive Era, which invalidated the regulation of manufacturing and agriculture generally observed as productive activities. Some scholars, such as Judge Richard Posner, Grant Nelson and Robert Pushaw, Jr. would be skeptical or disagree who argued to favor including any gainful activity (2001). Their works heavily rely on two earlier works on scholarship and chide some modern scholars, which concluded that an expansive view has never been refuted and their independent study corroborates it.

As a guide to the constitutional interpreter, some premise must be resolved in our understanding of original meaning and original intent. Original meaning is attached to the words, phrases, sentences, etc. and disregards any change to then meaning that may have occurred in the intervening years (2001). By contrast, original intent refers to the goals, objectives, or purposes of those who wrote or ratified the text. Then we can enlighten ourselves from R. Dworkin, that between what officials intend to say and what they intended, expected or hoped would be the consequence of their saying it. For the confusion, however, we may get better to harbor the method on one's normative rationale for the originalism. For those, original meaning originalism stems from the legitimacy of founders as command givers, who wanted to lock in the writings and adhere to it until it changes (2001). This position cherishes the historical evidence, typically prefers evidence of usage that is most closely associated with the measure's drafting and adoption. The evidence in this case would not merely be more historical, but one that most clearly indicates the public meaning of text. The extrinsic evidence may play to complement and narrow the scope of possible meanings, which could show how persons used the words. Second, we have to distinguish between 
interpretation and construction (2001). Practically constitutional construction has to be made indispensable if to dispose the case or controversies. We generally do not agree that we could contravene or fail to respect the plain language of constitution made clear from the original meaning of provision. Hence, the original meaning is perhaps foundational to govern, but often the ambiguities or vagueness occur leading to the necessities of construction. Originalism is warranted as a theory of interpretation, which is noted as a method of determining the meaning of the words in the Constitution. As Keith Whittington commented, constitutional interpretation is essentially legalistic while constitutional construction is essentially political (2001). This role of constitutional construction would implicate much in the current practice of government, which helps transform the constitutional theory into constitutional practice. As we experience a lengthy reasoning of court, the process of constitutional construction fills the gap within original meaning. In the view of Barnett, the constitutional construction should not be wholly political since interpretation may be limited to derive the abstract and general principles as distinct from the rule of law or choice of alternative rules (2001). The rule of law may be deemed political, but can be more correct to view from the normative lens or public administration as consistent and reliable, as we see the stare decisis or legal stability and predictability. Therefore, the constitutional construction would be made intricate with an intermediate doctrine to make the vague parts of constitution rule-like. The standards or principles that lie outside the text can authorize the supplementation of the text by other materials. The broad or undetermined meaning could be saved by the construction so as to be faithful and exhaustive for the reduction to legal rules. Therefore, the constitutional construction should be a vexing job from the normative lens and reality of disputes, and neither be wholly political nor become detached from the original meaning of provision. The constitutional construction conceptually may embroil the original intent originalism (2001). An extent of persuasion on the contemporary circle of jurors would not be certain whether the original intent must be primate in the process of constitutional construction. The constitutional construction eventually would be a choice of rules from the construing to determine original meaning, which would come in the present context of controversy and prevailing elements of humanly, political, economic and societal inputs or environment. The constitutional interpretation turns to be empowered to regulate the nation and society once construction occurs. Original intent could be infused and might be authoritative in some aspect where we generally receive the founders as teacher other than wardens (2001). From the work of Barnnet, other phrases come to be defined beyond the term, "commerce.” In sum, the construing of commerce clause to guide the public administrators may come in this way, "Congress has power to specify rules to govern the manner by which people may exchange or trade goods front one state to another, to remove obstructions to domestic trade erected by state; and to both regulate and restrict the flow of goods to and from other nations (and the Indian tribes) for the purpose of promoting the domestic economy and foreign trade” (2001).

\section{US v. Maghadam}

The case I selected for this week assignment is titled US v. Moghadam (Website Findlaw, 2014). In this case, the defendant was convicted to violate the trafficking law of sound recording practices (TLSRP), and appealed to the federal appellate court. The policy area of intellectual property would fall within the federal jurisdiction exclusively, but the concept would require some tangible product. Hence, the commerce clause would be contended whether the Congress can exercise a jurisdiction. The Appellate court found that 
the TLSRP can well pertain to the scope of commerce clause, which was intended to embody the federal power for a free flow of interstate commerce. In 1994, the Congress enacted the TLSRP which penalizes the illegal sound recording of live music performances, its transmission to the public as well as the sales, distribution, and other related activities (2014). The appellant Ali Moghadam argued that the statute was invalid because the Congress has no authority to regulate. The prosecution claimed that the Copyright Clause would confer such authority. Alternatively, the Commerce Clause would constitutionally allow the federal power to intervene and regulate the market. A first argument from the prosecution invoked the copyright clause where the Congress can grant a copyright for the statutory period in the benefit of authors and inventors, which would be exclusive and in the purpose of promoting the science and arts (2014). The appellant attacked that an authorship in the meaning of provision would denote any fixed form which eventually means a tangible form to be protected as always in cases. Live music performances would get outside the ambit of provision according to his assertion. The Court avoided this issue because it could find another ground to legitimate the statute. The Court rather considered an argument of Commerce Clause whether the regulated activities substantially burden an interstate commerce on the reasonable ground (2014). As the Congress has grounded their enactment from the Copyright Clause, the Court could not adequately refer to the evidence of legislative objective and process. Nevertheless, the Court could fully address the issue of Commerce Clause. The jurisdictional provision was not provided in this statute, which partly evinces that it could be a basis for the commerce power. Nonetheless, it would be merely circumstantial that the Court could still fill the jurisdictional element and the Commerce Clause could make the statute valid. The statute explicitly regulates an act which substantially affects the interstate commerce and foreign trade. Provided if the trafficking was conducted to pursue a monetary interest, it embroils the commercial nature (2014). As the traffickers would deal via an unpermitted route, the prospective market size would reduce, which shows its effect on the commerce to make it satisfactory to glue in the two strands, say, scope of congressional power and Commerce Clause. A more important question in this case lies whether the Congress purposefully avail of Commerce Clause to escape from a specific conferring by the Copyrights Clause (2014). The Court would favor to support that each conferring clause could have an independent basis on its own, and the scope of powers need to be construed individually and independently. Therefore, one clause may not be sufficient to base a specific exercise of congressional power, but still the other ground can work to legitimate a congressional action. The Court opined that the issue of constitutional structure and authority should be made distinct from that of legislative discretion or leniency. Although some trademarks may lack an originality requirement often respected in this area of public policy, the Congress, nevertheless, could enact an act to protect them. If the legislative authority exceeds a structural ambit of the Copyright Clause, however, the Court may get it tougher since the purposeful evasion from the Copyrigt Clause through the Commerce Clause would increase a tension in view of the original intent originalism. The Court reached a conclusion after the careful review; (i) the statute can be verified on the ground of national commerce power (ii) under the special circumstances, the Commerce Clause could apply to the case where the Copyright Clause either fails to cover or excludes as impermissible. The Court typified to support their conclusion that the similar extent of affordance to protect a copyright, though exceeding a limit set with the strict legal terms, would not directly contradict the Copyright Clause. The statute, in this understanding, also provides a chapeua about the term, "fixation." (2014) 


\section{The Interstate Commerce and Federalism}

The United States would be a federal union as subsidized by various states. The Supremacy Clause provides a traffic light in terms of the normative hierarchy, which intended to erect the federalism for common welfare. There would we were surrounded with the hints and implications that the federal government would be supreme and undergirds a scope of national affairs with an upstaging hand over the state authority (Richard, A. E., Michael, S.G., 2007). Nonetheless, we can ascertain in the constitutional language, such as state sovereignty in the $11^{\text {th }}$ amendment and reserved power in the $10^{\text {th }}$ amendment. The conflict among the federal, state, local governments would not be seldom indeed, given the role of governments would squarely bond into every corner of public lives. Hence, except for the nation-sensitive area of public issues, such as war, diplomacy or treaty, it would not be easier to resolve the conflict in any simplistic way. We can perhaps have made ourselves acquiesced of several provisions to place the federal and state power in the meaningful and interactive context of thinking (Bodenhamer, D. J., 2007; 2007). How the federal government can draw upon a scope of empowerment to regulate and provide for the liberty and general welfare would be one strand to think about? How the conflict can be resolved in case where two separate sovereign powers decide and act would arouse some structural concern. These perhaps would be two vexing questions to shape the American federalism for the founding fathers. The federal constitution would specifically enumerate the scope of federal power and prohibition against the state power. For example, the Commerce Clause would grant the power and authority to regulate the interstate and foreign commerce. The States could not be allowed constitutionally to confer a foreign nobility nor impair the existing contract. That could be viewed to guard for the federal interest and integrity or uniformity of union and might be critically desirable to defend the nation against a foreign disruption. As the time was inchoate and war-like tension for the earlier republic, the words, terms, phrases, and sentences need to be construed in the original meaning or original intent, and we can find any best interpretive alternatives. That is an important thread, which turns to refine the work of constitutional construction. The constitutional construction would be pivotal to infiltrate this linguistic artifact with a practical challenge and realistic factors, which, therefore, should be political, normative and societal (Clark, B. R., 2003). It is to choose among the alternatives of rule possibly standing from an interpretation elaborated on the original meaning and intent originalism. For example, we can discuss the etymology on historical evidence about "commerce," "regulate," "among several states” used in the Commerce clause. The Supremacy Clause may require an original intent to focus on filling the gap arising from its vagueness and ambiguities (2003). It would cast a doubt if the Court would employ the double standard on federalism, which would be textually or historically unsupported. The scope or indication of "federal laws" might not be determined, and a typology among the sorts of federal law could not be espoused in favor of the Constitution over the federal statutes. The original intent and etymology, logic, metaphor and analytical thinking could locate the adequate understanding of constitutional clauses, including the Supremacy Clause. The Supremacy Clause mandates the federal laws, say, the Constitution, federal law and certain treaties would preempt the state laws if found in the same ambit of subject matters (Laureate Education, Inc., 2009; 2003). Hence, it provides a normative ordering between the federal and state laws, which could be shared as same by the state constitutions for the sorts of state and local laws. The Supremacy Clause, therefore, would be an institutional bulwark for the federalism. 
Federalism could be viewed in several points. As per its cause of formation, we can identify a subtle difference if some would fear to unite, and others may be compelled to get along in a desirably weak form. The United States would perhaps pertain to the first, and the post-war Germany would fall within the latter class. The territorial size might be one important motive if we are given to think about the adequacy and propriety of public administration. The earlier years, they would not be modernly equipped to reconnoiter or survey their lands. We may recall that George Washington ironically had a occupation as a surveyor. The current territorial size would perhaps be an idealistic form to deliver their colonial need of rule and as subjectivity to the imperialistic King. The fall of former Soviet Union in 1990's eventually gave a birth to the Russian federation of Independent Nations which also implies that the kind of situation, crisis or war, might lead to federal deals for the political purpose. As per its extent of state attribute, federalism, as a corollary from the cause of formation, would be placed as median between the stronger unitary government and weak of international organization. As per its repercussion, federalism, despite its contingency in character, could evolve itself to offer a paradigm of statism and ideal state of interchange or public expediency (Richard, A. E., Michael, S.G., 2007). It is neither innate nor natural as a paradigm of polity or unit of public administration, but could be horned to become concrete on a case by case basis. Germany and United States simply demonstrates that the federal government can excel with no expensive transactional costs or expenditures. A cost factor to manage the federal system would be set off from various others, such as adequate territorial size for efficient public administration and others and as indemonstrable quantitatively though. The European federalists would be one interesting peer in the contemporary federalism on the planet, who would consistently advance, but be countered by the European socialists or national realists. For the successful cases, federalism would redirect the structure and authority of public power, and often they would ensure a federal supremacy in one way or another. Along with the institutional ordering and hierarchy of norms, it may echo that one critique for the federalism bites "Some of federal offices only without the due regards with various states as element and basis for the United States Politics" (2007). Hence, the implications from the Supremacy Clause would be vast although we are merely given one sentence in the Constitution. The public agents including a judiciary may be advanced to look around domestically and internationally when they undertake a Supremacy Clause issue. That is especially because a certain treaty is deemed a federal law and also because the community would no longer be any same with the times of ratification.

\section{The Federal Preemption and United States v. Arizona}

April 23, 2010, the State of Arizona enacted "Support Our Law Enforcement and Safe Neighborhoods Act”, which includes a strong measure to regulate illegal aliens (Jeong, H. J., 2012). The federal government and public interest group opposed that state action. The most important reason to oppose this Bill lies in its foreseeable harms that would eventually result in some discriminatory administration against the Hispanic. According to this Bill, the police officer has a mandatory responsibility to check an immigration status if a due context of suspicion arises. Therefore, it would highly be likely for the Hispanic populace to be subjected to police stop and identification given they are colored and most notable of illegal aliens. A civic group, such as the American Civil Liberties Union and Mexican American Defense and Education Fund, claimed that such high likelihood of discrimination would disintegrate the unity of Union and threats a diversity and social harmony (2012). A number of Congressmen, President, and other state governments generally expressed a concern and 
disfavor against the Bill. Particularly, President Obama delivered a speech to precaution on its adversary effect on the Nation, which stressed on the fairness, credence on the public police and whole of national community. Other progressive states or cities, such as Oakland, Minneapolis, Denver, Seattle had boycotted a transaction with the firms and businesses headquartered in Arizona (2012). Despite its seriousness, the Gallop poll reported only $75 \%$ of people know this Act, and that $51 \%$ of them would agree on it. Only $38 \%$ said that they oppose the Act. Other polls from the New York Times and CNN had not differed. This result perhaps reflects a prevailing apprehension that the economic and social expense expended by the American society would exceed their contribution. Governor Jan Brewer and, Kris W. Kobach, a leader of this Bill, spoke for public support that the worse possibility of discriminatory enforcement could be ensured against and that a relentless increase of social expenditure spent for the marked number of illegal immigrants become now irresistible. Other states, vastly southeastern states, such as Georgia, Alabama, Utah, Indiana, and South Carolina, also moved to enact the anti-illegal immigration acts (2012).

The Act involves a federalism issue how to allocate properly the power to regulate an illegal immigration between the federal and state governments (Richard, A. E., Michael, S.G., 2007). As two governments have a different interest and resource in the immigration policy, they would not entirely agree on how to respond with the illegal immigration. While the border states would suffer from an excessive administrative expense, the federal government would face with multiple factors, such as revenue income, international relations and diplomacy. The Constitution had not stated which government is responsible to regulate the illegal immigration. On the citizenship and naturalization issue, Art. 1, Sec. 8, Para. 4 provides that the Congress shall enact a national law. The regulation of international travel and deportation would not be dealt expressively, while the Supreme Court generally perceives it within the federal power on the basis of the Commerce and War Making clauses. The number of illegal immigrants began to increase since 1980, has grown steadily during 1990 's and amounted to about 1,800,0000 according to a statistics released from the DHS in 2010. Illegal aliens brought a rather extensive impact on the public policy, i.e., sanction of employers, owners of rented housing, Medicaid, social benefit and education (Jeong, H. J., 2012). This made the issue distinct from those of citizenship and naturalization or deportation. The state government inclined to use the Tenth amendment historically to expand their jurisdiction, and federalism would perhaps be a counter-thesis. The Supreme Court recognizes an original view of respective jurisdiction as independent among another. The Federal Supremacy requires that the federal law supervene to resolve the conflict between two governments (Hickok, Jr., E., 1990). Unless any explicit authority was to be found within the federal laws, the Supreme Court undertakes to look into two points. The first is to inquire if the area of regulation falls within the traditional state role, such as police power or employment issue. When it finds the case fall within this category, a presumption against federal preemption will be granted. Then the Court can ask whether the state law for regulating illegal aliens can be viewed as an immigration issue. The Supreme Court in the Passenger elucidated that the immigration issue, in the end to constitutionally determine the federal authority, would be characterized "Who should or should not be admitted into the country and the conditions under which a legal entrant may remain? (2012)” The immigration jurisdiction under this definition had been held to fall within the federal power according to the court precedents (2012). The second point is to ascertain the legislative intent of Congress. The intent of Congress would be determined by referring comprehensively to the specific provision, words and paragraphs in a logical coherence, and 
existence of related statutes. Often the intent would not be delineated clearly which can lead to make a different opinion standing if in the same nature and scope of statutes. In this case, it would be blurred who is a legitimate government to regulate the issue. The objective of this Senate Bill is to achieve a drastic attrition of illegal aliens by a forceful regulation. It could bring a thorough and exhaustive enforcement of federal act, which discouraged them from a settlement or led to a voluntary leave (2012). It enabled to avoid an entire retreat or strong measure, such as deportation, the manner often to be practiced by the state governments. It uplifted a public measure of state police, but the federal government sought a preliminary injunction in the federal district in July 6, 2010, which was on the ground that the Act disparaged with a uniform administration of immigration policy (2012). The district court granted an action partially and denied some claims. Art. 2 provided that the arrestees have to be checked before a release and that a mandatory stop and identification are required in the event a reasonable suspicion would exist. Art. 5 required to make it a petit crime if the employers hire an illegal alien. Art. 6 authorized to arrest without a warrant when a probable cause exists to suspect that he or she committed a crime to merit a compulsory eviction. All these four counts of claim were granted (2012). Part of Art. 5 was denied, which provided a criminal penalty for the transporter of illegal aliens. The state government appealed to the $9^{\text {th }}$ Circuit which was denied.

\section{Reference}

Coenen, D.T. (2003). Constitutional Law: The Commerce Clause (Turning Point) New York NY: foundation Press.

Website Findlaw. U.S. v. Moghadam. Retrieved May 3, 2014 from http://caselaw.lp.findlaw.com/scripts/getcase.pl?navby=search\&case=/data2/circs/11th/ 982180opn.html.

Jeong, H. J. (2012), The Legal Dispute among the Federal and State Government concerning the Unauthorized Immigrant Enforcement in the United States: focus on the Federal Preemption Doctrine to the Arizona State Bill 1070. Kyung-hee Law Journal 47 (1), 314-, Seoul. South Korea.

Richard, A. E., Michael, S.G. (2007). Federal Preemption: States' Powers, National Interests Washington D.C., USA: Aei Press.

Clark, B. R. (2003). The supremacy clause as a constraint on federal power. George Washington Law Review, 71.

Barnett, R. E. (2001). The original meaning of the commerce clause. University of Chicago Law Review, 68(1), 101-147.

Great Neck Publishing (2009). The Constitution of the United States 1787, Great Neck Publishing, 18.

Hickok, Jr., E. (1990). Understanding federalism. Perspectives on Political Science, 19(4), 216. 
Laureate Education, Inc. (Executive Producer). (2009). Fundamentals of law and public policy: The courts - Federal, state, and local conflicts. Baltimore: Author.

Okyeon Yi. (2013). Education Welfare and American Federalism. Korean Journal of Area Studies, 31 (3), 165. Seoul. South Korea 


\section{A Federal Judiciary and State Courts}

The judiciary in the United States was structured in response with the federal system of government. On one hand, the state courts are required to call upon the administration of justice under the state constitution (Methods of Judicial Selection, 2014). For the federal government, the federal judiciary is responsible to assume the role and responsibility under the Constitution of United States (Congressional Digest, 2005). This dual dimension of court system is inextricable since the federal government only could be grounded on the enumerated powers specifically mandated by the federal constitution. The federal jurisdiction was based on the Art. 3 of Constitution where the Supreme Court was called upon the original and appellate jurisdiction. As we learn, the case or controversy requirement defines a horizontal division of federal power from the legislative and executive branch. The appellate jurisdiction was to be surmised to erect a vertical line of court hierarchy, which occupies a vast of caseloads for one Supreme Court and 13 Circuit Courts. The lower courts are to be created by the Congress as it considers due and appropriate except one Supreme Court. The Supreme Court is a constitutional institution that the Congress could not derogate. Now the 94 federal district and 13 Circuit provinces had been prescribed by the federal statutes (2005). The federal courts are called an Article III court, which should be distinguished from the Art. I court. Article I courts could be created through a congressional enactment, which often are called an administrative tribunal or independent agency for the adjudicatory role. The judges of Art 1 Court would not be constitutionally guaranteed of a kind of constitutional privileges, such as lifetime tenure, limitation of removal, and protection from decreasing salary. Article III courts, hence, would be considered more rigorous and integral to ensure a constitutional design of check and power, and would be a vertebrate of independent judiciary ideals for the civil democracy. The federal courts are competent to act on the basis of Constitution and organic statutes. They generally are competent to exercise the subject matter and diversity jurisdictions. Therefore, if the case or controversy involves a federal issue, it could condition that the federal judiciary could only be competent to resolve that issue. The disputes between the citizens of different states or between citizens of one state and other state government would fall within the diversity jurisdiction. Often the state courts consider the laws of state, and the federal court would deal with the federal laws. Nevertheless, the federal courts are required to apply the common law of state where they sit in in the diversity disputes.

\section{A Selection of Federal Judges}

The federal judiciary is politically important provided that the United States are a federal union (Kerwin, C. M., Furlong, S.R., 2011). They are responsible to act as an important policy maker, and selective echelon to maintain the integrity of federal system. The number of Supreme Court justices had been six until the mid of 19 century, and rose to nine who are a pedantic circle to quibble on a most of important public issues in the US. They can be compared with 100 members of Senate, and perhaps several thousands of the House of Representative. The 13 Circuit Court judges may range around as similar in number from the Senators, and about three thousand district court judges would be compared as close to that of Representatives. The justices and judges of state court are selected in several ways, which covers a partisan election, gubernational appointment, peer vote, senatorial election, general election, at pleasure of chief justice, and so (Methods of Judicial Selection, 2014). Hence, the ways would diverge as the state constitution prescribes. The federal judges including justices of Supreme Court are appointed by the President and approved by the Senate, as the appointment clause mandates (Congressional Digest, 2005). The presidential or Senate 
nominating commission practically plays an important role to evaluate and screen the potential candidates from a pool of resource. The Department of Justice and Senate nominating commission has practiced an informal process although no formal laws or regulations would dictate specifically about a qualification, expectations or other standards. Two historical events perhaps demonstrate that the selection of federal judges should be highly political. One would arise from a backdrop for Marbury v. Madison that the appointment of public peace court judges was politically entangled with two successive administrations, say, Presidents Adams and Jefferson. A political motive and conflict even had embroiled holding a delivery of appointments for the judges of public peace court. In the court packing plan, the progressive president, Roosevelt, was frustrated from the challenge of conservative justices, and attempted to enlarge the number of justices to make his command rather effectively. A political influence would be exerted in a subtlety either in the Senate approval process or nomination by the President with an assistance from the presidential nominating commission. The partisan ideology between two major parties, Republican and Democratic, could be viewed as differs between the conservative and liberal or progressive (Jaquette, I., 2007). Such ascription would be illuminating to refer to the perhaps differing attitude of Supreme court justices although we may have other terms or details on the respective political issue. As the spoils system to plant top officers had been prevailing, the President almost always must have been definite to desire staffing their peer thought companions in the post. Since the lifetime tenure contributes to age the turns of appointment, some president might have no chance to appoint the Supreme Court justice during his tenure. A surfeit of empirical works generally supports a high tendency of Supreme Court justices to be loyal to the nominating president or his party affiliation. A Senate approval would also affect the selection of federal judges, but in some different way. The opposing party may disclose their disfavor by rejecting a nomination or procrastinating the approval process. In one recent case, Sung Kim, who was a Korean origin and nominee as an US ambassador for South Korea, had experienced a delay in time of approval, which was alleged as a political plot to impress the disfavor of ruling Democrat.

\section{Political Ideologies of Judges}

The political ideologies of federal judges would be a factor leading to a different ruling in the sensitive public agendas (Kerwin, C. M., Furlong, S.R., 2011). It evinces that an important public policy would be highly malleable to the attitude of justices, his personality, philosophy, perhaps as shared in some from the normative common ground as a lawyer. We may invoke a traditional notion of legal province, encompassing those private, public and intermediary. These basic three of legal dimension would help to elicit a correlative between the political ideologies and case outcomes (Jaquette, I., 2007). The first two are generally conceived as a hard ground and firm to share normatively. For example, a pure contract or tort law cases would be neither or less related with the political ideologies. A pure public law issue, such as the exhaustion of remedy for judicial review and "on record requirement" as stipulated by the APA and necessitating a formal process in the administrative rulemaking or action, would be less tempted of or contended by the differing political ideologies. A well settled law could be located readily and shared by the justices. Probably, the intermediary nature of issue, vastly social or familial as a tangle of both strands, would pose a challenge between the conservatives and progressives. For example, the nature of labor union, parental rights in educating their children, public school system, right to privacy and abortion, church and religion, and those of kind would be a contentious area of public polices where the political ideologies of justices must be viewed as determinative of shaping a legal rule and 
system. For example, the justices appointed by President Reagan may favor a relaxation of hard standard involving the Fourth Amendment right in the case of students within the school (Torres, M., Jr., \& Stefkovich, J., 2007). Hence, strip search may be granted as constitutional more amply in the educational or corrective purpose. The school autonomy would be respected to flourish the liberal and conservative ideals when we consider a procedural justice of law in the disciplinary proceeding of public school. The progressives may require a similar standard of Fourth Amendment rights, and favor imposing a stringent process to safeguard a constitutional value of due process of law for the accused students (2007). The conservative judges would emphasize the sectoral autonomy of community and limited government for the classic liberty. The progressive judges may gladly risk a more expensive government for a fine and advanced system under the big government as well as interventionist justice. A new deal package to reform the free market would be contended seriously to redirect the basic direction of American social and legal system.

\section{Reference}

Congressional Digest. (2005). Federal judge selection. Congressional Digest, 84(5), 140-160.

Jaquette, I. (2007). Boston University School of Law Merck KGaA v Integra Lifesciences I, Ltd: Implications of the Supreme Court's decision for the people who matter most... the consumer. American Journal of Law \& Medicine, 33(1), 97-117.

Kerwin, C. M., Furlong, S.R., (2011). Rulemaking: How government agencies write law and make policy (4th ed.). Washington, DC: CQ Press.

Torres, M., Jr., \& Stefkovich, J. (2007). Students' fourth amendment rights and the federal judgeship: Examining the link between political appointments and case outcomes. Brigham Young University Education \& Law Journal, 2007(2), 257-280.

Caperton et al. v A. T. Massey Coal Co., Inc., et al. Retrieved May 7, 2014 From http://www.supremecourt.gov/.

Methods of Judicial Selection. Retrieved May 7, 2014 From http://www.judicialselection.us/judicial_selection/methods/selection_of_judges.cfm?state=. 


\section{Mass Media, Law and Public Policy}

\section{A General Thought}

The role of mass media is extensive to affect the law and public policy. The implications from this interaction would be conceived both positively and negatively in view of idealistic process in democracies. For example, the agenda setting theory holds a view, based on the empirical study covering 1968 presidential election, that a frequency and prominence in the news coverage determined a most important election issue. The theory was developed by MaCombs and Shaw, and followed up by over 400 pieces of research work to corroborate, develop and critique. For example, Cook et al suggested that the media influenced views about issue importance among the general public and government policy makers, who used an experimental design built around a single media event (Cook, F. L., Tyler, T. R., Goetz, E. G., Gordon, M. T., Protess, D., Leff, D. R., et al. 1983). The limitations of media, in service for promoting the democratic rule, also would be argued by two studies in this week reading materials. The conflict laden exposure of public issues in the news or television program can have a potential of misleading the public opinion. According to the study, the public perceptions of political institutions and political elites would highly sway. The study had been interested in the construction of the state of Union Address, and the ways to influence the attitudes and perceptions of viewers. It focused on the CNN's Crossfire and Inside Politics' coverage (Forgette, R. \& Morris, J. S., 2006). This odd simplification and strategic framing can make it a kind of contact sports lacking prudence and contemplation. One other source from Patterson also surveyed the limitations of media in public policy making, which analyzed by infusing a most primary characteristic of media, what is a time element (Patterson, T. E., 1998). In his thesis, the intrinsic of mass media as commercial establishments and professionalism would make a high social impact, but nevertheless comes short or contingent on a day to day basis. The factual accuracy and novelty are a crucial interest they pursue. The enduring issues would generally unfit within their work frame and ultimate ideals they respond with. The news reports may be matched with a parliamentary debate for our comparative purpose in effecting to transform the society (1998). Their commercial interests may also pull their direction of business "to attract and hold a large audience for advertisers” (1998). Their immediate concern would help to stay abreast of current affairs, hence, make them for "a relentless search for the Now" and turn the story into news if form and immediacy becomes ready (1998). Often their job is grounded on the episodic framing where the incidents, events, occurrences are translated into a version of news story. In this availability, the public would not be led properly to contemplate and make on enduring issues. They also prefer to place competing politicians in any controversies and contrast, which is called a strategic framing. It could serve to mobilize a public attention, but entails a weakness without the substance of policy agendas and corresponding exposure of public to the important and standing public agendas. Basically, we may hardly construct the news source or information readily on its own, which is thought as, "no politics possible at the speed of light” (1998). They routinely update the news stories, but on such day-to day basis of their work frame. In this operation, the running story may attract a focus from the public, who can center on the key event and may enable to manage comparable stories in the same caption or attribute of theme. A thematic framing may be identified in this case, but still a truth other than newsworthy reporting would not be any indispensable deal in their professional strife. Perhaps sensationalism would be one inescapable mental orientation to make them vulnerable and short-lived. The impact on law and public policy, in this viewpoint, 
would not be systematic, which requires a filtering from the public agencies and political institutions.

Mass media generally is attributed as "fourth branch," which plays an important role to engineer the democratic society. They lead a public opinion and frontier the new development of issues, events and occurrences. They are a vanguard to situate the community through the past, present and future context of meaningful construction (1998). They are a center of public attention, and mobilize the basis of policy environment. Their impact would be serious to move the policy makers since they have to be accountable for the popular will. For example, the poverty issue made disclosed by the mass media could alert the government to be more faithful and attentive. The information on economy or income disparity may be shared, and, through a specific focus of mass media, policy makers may be motivated to address the issue. As reviewed, the mass media may have some fabric to report, which may lack a precision and as prejudiced from the reality. Two notable fallacies may be charted over the past decades involving the running time (1998). Once the criminal activities were focused in the end to give a caution of safe society and breakdown of civility in the 1990's. Around the time of theme, of course, a series of murder crimes have been reported including the Rhode Island killing spree and serial murders in New York. Nonetheless, a systemic view does not warrant statistically that it was the period if the American public suffers any higher crime rate. The reality would be contrary. One other propensity can be found in the reporting of national economy. They routinely heralded a worse condition of national economy, trade imbalance, deficits, and a weak dollar. This would go as unsupported from reality given the US actually excelled in the economic competition against Germany and Japan (1998). The impact of mass media on law and public policy could not be overstated, and they actually orienteer the public opinion who ultimately prefer to recourse the accountability of government. They generally function to set an agenda and contribute to shape issue importance. They also undergird the direction of public policies and help to create an alternative. Nonetheless, the ultimate responsibility remains with the law or policy makers because (i) they are politically elected and assigned a power and competence to create or enforce the public policy (ii) we have no way only but to resolve a public issue or agenda, which is on a continued study and churning, sees it as enduring issue, and renders it as informed, systemic, monitored, prudent as cost-benefit analysis, procedural, and some form of participation.

\section{A Ferry Sewol and Some Reflection}

One recent issue offers a lesson, which involves a sea tragedy in South Korea. Its consequence has been enormous to impact the Korean public from a fundament. As reviewed, the role of media has been salient to inform and communicate the sad event. The egregious happening is needless to specify, and exposed a fundamental flaws not only within the national administration, but also in view of the totality of social system. The news media in Korea may be termed as an episodic or thematic framing in its attitude on the coverage of this event. It hit the headline news, on the day of accident, both in US and South Korea. A state visit of President Obama for South Korea was also decorated to have a silence of moment for the victims, and his schedule in Seoul was adjusted as solemn. The official tribute of a Defense Ministry, C. Hagle, in the memorial hall arranged inside the Korean embassy, and deep condolence from the heads of nations or politicians of United States had followed. The ads in the New York Times to claim, "Bring the Sewol to Light”, would mean a sharing and the quest of justice for this odd and problematic misfortune. I like to make a point concerning 
the incident's implication and media's role. First, the media would get easier to interact with the international community. Second, the media could create a moment to revolutionize a basic perspective and paradigm although it is true that, as contrasted, they are unfitted to deal with the enduring issues. Third, the media's strengths would be more efficient in the wider scale than a limited, but intense domestic interchange. Fourth, we need to consider a new mode of communication and make a comparative analysis as covers the traditional and online mode of media as well as cyber space of public communication. The international context may bring to frontier a new horizon to affect the laws and policies. Their principal job is to favor a newsworthiness than the truths, but the agenda setting role is fairly appealing if a view or opinion is foreign or exotic. The interchange of culture and wisdom generally can make a positive effect on the law and system of nation, but with a precaution in some cases (Laureate Education, Inc., 2009). The national strategy may permit a sifting in the extraordinary context of exposure or interchange. Information is a hard subject which underlies the enforcement of laws and creation of public policy. The mass media would tacitly be compared with, for example, the national intelligence service, for its agility and speed to respond (2009). During the reporting of Sewol tragedy, Korean public actually deplored when the media disclosed a vulnerable system of national sea rescue operation by readily illustrating a foreign paragon. In this light, the media may be considered more reliable when the important international issues rise as an agenda or issue. For the second, the media may not be exhaustive about the kind of values, say, system, research, record, personnel resources, and so. It generally brings them to be inadequate for a continued or systemic basis of policy pursuit. Nonetheless, the politics or social system may not entirely depend on scientific truths, but the moment of fundamental turns, perhaps somewhat sensational in deals and sympathetic to impact, would have some relevance as demonstrated in history. In this light, the media would be any more effective agent to create a social atmosphere and attention. In the case of Sewol, two aspects fueled to aggravate a public emotion that most victims had been youths, and that they were led to deaths in any absurd way. It infuriated the Korean public. It seems highly probable that the Korean government would alter a chronically illserving institution and system. For the third, the intensity of knowledge or information and more systemic expertise may be found in the domestic context and one attribute as distinct between the international and domestic deals (2009). This perception might be proven when the media generally was not rated as excellent in dealing with the Sewol tragedy. It centralized their focus on this key event, and compared through the past, present, and future. They illustrated many neighborly conditions which are vulnerable in terms of safety standard. Nonetheless, it seems to be dubious whether their news coverage has been persuasive or led the public into a sphere of enthusiasm and conscience. For the fourth, the advances of communication technology and new mode of access to the news are a factor to consider. This generally reduces a salience of the dual standard between the "domestic and international" when we consider the role of media concerning two dimensions. The remaining issue, then, would be who are ultimately responsible for the law and public policy in the democratic process.

\section{Reference}

Cook, F. L., Tyler, T. R., Goetz, E. G., Gordon, M. T., Protess, D., Leff, D. R., et al. (1983). Media and agenda setting: Effects on the public, interest group leaders, policy makers, and policy. Public Opinion Quarterly, 47,16-35. 
Forgette, R. \& Morris, J. S. (2006). High-conflict television news and public opinion. Political Research Quarterly, 59(3), 447-456.

Patterson, T. E. (1998). Time and news: The media's limitations as an instrument of democracy. International Political Science Review, 19(1), 55-67

Laureate Education, Inc. (Executive Producer). (2009). Fundamentals of law and public policy: News media - Law and public policy. Baltimore: Author. 


\section{Elements of Public Policy and USTR}

\section{The International Trade and Administrative Regime}

Interdependency among various nations in this global economy is needless to specify. Almost every country could not manage their national economy without the trade and foreign investment. In terms of law and public policy, the trade regime can be classed into three folds, to say, national, global and regional. The modern commerce states generally administer their national policy of international trade. In order to perform this mission, the administrative system would be afforded within the constitutional government and according to the pertinent statutes. USTR, Department of commerce and International Trade Administration are key players in this term, which create and execute their roles or responsibilities on the import relief, anti-dumping, subsidies, as well as requirements from the Super 301 and the like (Gibson, M.L., 2000). A regional level of trade regime may be found in EU, NAFTA, and MURCUSOR, which purports to boost the regional trade and economy. It would be founded on the regional treaties or compacts to govern the regime. For example, the provisions of NAFTA concerning the special tribunal conferred a jurisdiction of trade dispute among the member states would be largely accepted to effectively exclude the constitutional jurisdiction vested within the Article III courts. The global level of trade regime would be seen to crystallize as the 1994 WTO regime. The regime has transformed immanently from the weak form of 1947 GATT, which would not be wrong if we say, "a kind of constitutional regime in the management of international economy." The judicial nature of organization had increased as remarked, which instituted a reverse consensus system, cross-sector retaliation and orderly rule on the dispute settlement procedure. OECD, IMF and IBRD or World Bank would be a global scale organization which leads or influences the international economy. The scope of responsibilities or the ways to interact would differ from WTO, however. If the WTO is an organ for the real sector economy, IMF, IBRD or World Bank would administer the international obligations or execute the treaty provisions on other economic or financial commitment. For example, OECD would discuss a large spectrum of global economic issues than WTO, but they often act to merely produce a soft nature of norms.

The trade policy of US is an area which is to address in this final project. The policy area would deserve an extent of review since (i) the nation had long decades suffer from the trade deficit; (ii) it entails a distinct characteristic in terms of law and public policy (Hammond, T. H. \& Knott, J. H., 1999). First, the public policy would be national, but the quality of issues or problems might traverse the nation onto a complicated or multiple profiles of foreign nation or enterprises. Second, the trade issues came to be recognized as a top priority, and considered to be any more proper imploring on a strategic response. This strategic attribute would be involved with the rest of policy areas. Nonetheless this area generally profiles in more of that focus. For example, the fast track procedure established by the Congress was intended to respond speedily and faster with the challenge of national trade issues. Third, the USTR had recently increased its role and responsibilities to remedy the chronic ills of trade deficit, which inaugurated as directly responsible to the President of United States. This implies the importance of trade policy and urgency or immediacy to address the unfair or discriminatory practices of foreign nation against the US trade interest (Chung, J.W., 2006). Fourth, the policy area is not domestic in most aspect, but involves an aspect of negotiation and diplomacy. The international context of policy creation and implementation would explain much of policy elements, such as the structure or plane to be played by the agencies. A dealings with the multinational corporations, negotiation and 
compromise with the foreign nations, as well as respect for the international laws would feature more powerfully than other policy areas.

One administrative agency intended to employ for this project would be USTR. The USTR is one of presidential bureau outside the cabinet level, which is responsible to execute the roles set forth within the statutes. In understanding the virtue of trade liberalization and market access, the US has entered into numerous trade agreements with other countries (2006). The office is part of executive office of president. The head, US Trade representative, serves as a cabinet level, though not technically within the Cabinet, who would advise the President. The responsibilities of USTR are to develop and coordinate the policy of US international trade, generally covering the trade of goods and services, direct investment policy and oversight of trade negotiation (Hammond, T. H. \& Knott, J. H., 1999). It acts in interagency structure to coordinate the trade policy, resolve disagreements as well as to frame issues for presidential decision. It annually prepared the National Trade Estimate Report on Foreign Trade Barriers. The Report contains an investigation of significant trade barriers to US exports, estimates of the impact on the value of US exports, and the actions taken to eliminate barriers. An interesting point about this agency lies in the statute itself, which they are responsible to implement, to say, the Section 182 as amended of the Trade Act of 1974 (2006). The Act imposes "a mandate on annual basis to identify those foreign countries...The Act also defines priority foreign countries as those..." The USTR is also responsible to enforce the Section 182 as amended of the Trade Act of 1974 which obligates to do the same in concerns with the protection of intellectual property rights. It deals with the identification of and response with the foreign countries, who practice the inadequate and ineffective protection of IPR. The Uruguay Round Agreement Act complements with the Act in defining the role of USTR. The national and international obligations are treated in a different measure that URAA states that compliance with the Agreement on Trade-Related Aspects of Intellectual Property Rights does not include a country from being identified as denying "adequate and effective protection of intellectual property rights".

Under the backdrop and present status of Us trade administration, this article intends to deliver a synopsis of USTR's public meaning, which will be illustrative and accorded with the several major elements dealt in the law and public policy.

\section{A Trade Statute and Role of USTR}

A most important statute would be the section of the US Trade Act of 1974 (Pub. L. 93-618, 19 U.S.C. 2411), in which the USTR is responsible to enforce under the authority and command of President (2006). The power and responsibilities of USTR would be seen as distinct from the normal line of trade and commercial policy institutions, such as DOC, ITC and the like. Three important elements could be posited to distinguish : (i) the trade policy and issues within the USTR would be aggressive than defensive and thus principally structured to make it auspicious for the trade interest of US (ii) the dynamism, interaction and official line to report would be simple, strategic and central (iii) their responsibilities would be creative, formulating and negotiation-intense than application of laws or rules already settled (iv) their responsibilities are shaped in a compelling commitment that the discretion, interpretive leniency, and final power to enforce would rather not depend on the statute itself, but on the delegating command from the Congress. Hence, they would act as the kind of police power to sanction and be retributive of the identified scope of wrong nations. Consider the anti-dumping and subsidies practices of commercial agency in the US. The US is one of 
most patronizing countries who employ those two measures to restore the trade justice. They may levy the anti-dumping or countervailing tariffs to efface the effect of unfair competition from impermissible subsidies from the government as well as unfair manipulation between the foreign and domestic market (Harrington, C. B. \& Carter, L. H., 2009). We use the words, "countervailing and anti-dumping," yet to be reluctant to characterize as sanction or retribution unlike the Super 301. The statutory terms and requirements in the former two traditional sectors of trade policy are pretty defined and could be agreed if otherwise would be contended in the courtroom. That could be seen not compatible with the manner and paradigm of deals from the Super 301, which actually is extraordinary from the normal ways of trade statute. The terms and requirements are not reduced to the narrow and most appreciable form of concepts and provisions. For example, they use the terms, unfair, illegal, unreasonable, discriminatory, or trade interest of US and the kind, which could be vague or ambiguous in variance with the actors and interpreters. We note, at this point, that the trade policy is not surely insulated from the international network and concern that may possess some extent of international character. The Super 301 is certainly a domestic nature of norm in the formal viewpoint, but its impact would be multi-national. Most importantly, we have thus transferred some of important state function on the trade and international commerce to the international organizations, notably WTO. It operates on the basis of multilateralism not only from ideology, but also with an impeccable attribute of dispute settlement mechanism. The kind of controversies as described in the terms above illustrated are the scope of jurisdiction envisaged to be adjudicated by the WTO dispute settlement body multi-nationally, not by the US authority unilaterally (Clark, B. R. , 2003). This argument would be advocated by a number of international scholars while the countervailing argument could be framed on the legal ground by many national jurists. The matter brought the permissibility and due extent of extraterritorial application of domestic laws, and reveals an inherent disagreement involving the state sovereignty conception and international commitment. We often prefer to approach this issue via the international comity and diplomatic solution other than views of legal orthodoxy. Nonetheless, the Super 301 and USTR now serve interestingly the national needs to address a public goal despite the international criticism. On the other, the process to create a policy and implement would be facilitated with the simple and strategic line of authority where the President is to take all appropriate action, including a retaliation, to obtain the removal of any act, policy, or practice of a foreign government that violates an international trade agreement or is unjustified, unreasonable, or discriminatory, and that burdens or restricts U.S. commerce. There are two ways to take a process. It can be selfinitiated by the USTR, while a petition filed by the business or industry group would offer a thread to invoke the process. A policy goal of this act would defend the trade interest of US against the unfair, unreasonable, illegal and discriminatory practices of foreign nation. The peculiar aspect to a public concern underlies a mandatory identification of such countries, annually as a priority of countries. The USTR, then, is obliged to undertake the process followed by negotiation, settlement in the form of compensation or elimination of trade barrier, as well as request of WTO dispute settlement proceedings for cases involving the trade agreements.

The similar institutions were added as we see in the Special 301 Amendments involving the intellectual property rights. This would come in response with the increasing profile of intellectual property in terms of national economy and welfare of US citizens. The practice of President and agencies gradually raised the extent of policy focus on this sector. However, we also need to be aware that the Trips Agreement of WTO entered into force 
which potentially diminishes its roles as an international umpire. The concept of international trade has shifted intensively from the 1947 GATT, and highly been reinforced in the moment of WTO inauguration, 1995 (Chung, J.W., 2006). It pursues a perfect and idealistic market where the businesses could be advanced without the barriers and fairly. Trade liberalization and fair competition would be central so that the national government has to be neutral and is not desired to be auspicious. It is a grey area hardly defined in any absolute legal command, but morally in conflict with the WTO ideals. Typically the words, the "interest of US trade," would increase a public skepticism if other than the legitimate state or public interest within the WTO or other frames of international law, such as public health, humanistic cause, public order and morality and so. As stated, the policy area would be required of multiple contemplations, both national and international as well as concerns of private sector. The jurisdiction of USTR would involve an aggressive or highly discretionary measure beyond the normal administration of trade justice where we can identify major roles of Super 301, Special 301, and Safeguard Act. The words, "aggressive or highly discretionary," often would not readily be adaptive with the law enforcing authority, which, however, could survive in the trade policy area (Gibson, M.L., 2000). A new protectionism in the 1970's or 1980's would surge to respond with the assails of new industrialized economies in the Us market. The safeguard measure could be seen as one of most practical measure in this national end (2006). The import relief often would play a key role in favor to protect a complaining sector of industries. The elements or requirements would differ a little in quality so that an import relief requires of the final approval of President to issue or enforce. The findings, "significant injury to domestic industries" or so, would work less definitely on any quantifiable terms. Therefore, the enforcement of Safeguard Act is not the same with anti-dumping or subsidies measure or other measure of tariffs act. It would be partly because the nature of trade measure would have a cause only to save the industries and has a quality of emergency, albeit without any fault from the trade partners. US also upgraded their trade policy from the demand of industries and squeezing pressure and from the chronic of the trade and financial deficit of federal government. A new initiative resulted in two institutions, Super and Special 301, which would be critiqued, "a unique public law to advocate a private or economic interest" as commented from the British jurists (Harrington, C. B. \& Carter, L. H., 2009).

\section{Three Rules and Enforcement of USTR}

The three rules, in this thesis purpose, would be opted for under this background, which would include the Executive Order 23116, and two standards of the Super 301 and Special 301 legalized thereby. Hence, our focus would be given to those which perhaps are ingenious as distinct from the normal dealings of law. In terms of the authority and accountability of agencies, the rules expose a very good subject of public administration studies from several points (i) two political branches tend to be highly collaborative and mutually reinforcing on the urgency of policy issues (ii) the congressional control is any more powerful to compel and coerce a specific action depriving of the interpretive leniency often ensconced within a scope of statutes (iii) As independent agency directly responsible to the president outside the cabinet system, the enforcing authority can exploit the fast and strategic measures to address a seasonal nature of trade issues (iv) the Act would not be a permanent subject, but at the renewal option of president in short term of years. The three rules would provide the statutory terms and principles that the USTR could enforce (Iancu, B., 2012). The requirement to identify and negotiate with the priority group of countries is compulsory and to produce an annual report containing the executive summaries, elements, list of countries 
and others. A notice and comment set forth in the APA apply in the purpose to comply with the due process of law and to increase a democratic quality of administration. Under the Executive Order 13116, USTR is required to submit to the Congress each year a report identifying foreign countries who fail to comply with their obligations of international law or maintain a discriminatory or unreasonable practice against the trade interest of US (Chung, J.W., 2006; Laureate Education, Inc., 2009). The identifiable harm or damage to the trade interest, of course, constitutes one important requirement since the non-intervention doctrine of domestic issues would be firm in the practice of international laws.

A statutory principle would begin as most problematic through the less stage, i.e., legal violation first, discriminatory second and unreasonable third. The response with this differing extent of culpability would lead a different treatment in terms of the administrative decision making. The 2011 report could be surveyed briefly to show the ways that the USTR execute the policies and standards. The report grounded a legal mandate at first that: 1 ) have failed to comply with their obligations under the WTO Agreement on Government Procurement, Chapter 10 of the North American Free Trade Agreement, or other agreements relating to government procurement to which that country and the United States are parties; or 2) maintain, in government procurement, a significant pattern or practice of discrimination against U.S. products or services which results in identifiable harm to U.S. businesses, when those countries' products or services are acquired in significant amounts by the U.S. Government. The USTR, then, would be compelled to initiate an investigation under section 302 of the Trade Act of 1974 (Harrington, C. B. \& Carter, L. H., 2009). If the matter is not resolved within 90 days of the submission of the report, the international dispute proceeding, inter alia, would be initiated upon the Executive Order, exclusively on the finding that the rights of the United States under an international procurement agreement are being violated or that a significant pattern or practice of discrimination exists. A perception or understanding of the policy measure or effect would come antipathetic as expected from its intrinsic and policy goals. Most importantly, the trade issue could play at forefront with no dissidence or counter views, but with little exception, such as heard in the environmental or social justice advocacy. R.B. Zoellick, the trade expert and who formerly served as an US Trade Representative commented "Together these reports underscore the Administration's strong commitment to ensuring that Americans reap the benefits of the trade agreements that we negotiate" (Chung, J.W., 2006). He added "They also demonstrate the importance of vigilant monitoring of U.S. trade agreements and quick responses to non-compliance - including through the use of WTO and NAFTA dispute settlement procedures, WTO oversight committees, and U.S. trade law tools." (2006). Two important points were emphasized with respect to the domestic consequence of policy and its collaboration with international bodies or administrative regime. In his statement, we can see that the law and public policy in this area of important national priority are highly interwoven with the international structure and authority.

\section{A Compliance and Oversight}

If we consider the issue of compliance and oversight as well as the judicial control are a main body of subject concerned and discussed in this discipline, his latter part of comment obviously touches on the core of attributes of trade administration (Woolf, L. \& Jowell, J., 1995). That could be contended or critiqued, however, as introduced and from the very reason of different footings or political stance. Mostly international in concern and approach, they pointed out two evils that can abridge a rationale and structure of governance. 
First, its lobbying power can impact and be realistic to force a domestic measure compelled overriding the primacy of self-determination. In the Jamaican case, the threat over negotiation and eventual remedy in the interest of US could be traced. The US trade expert took a lead of domestic legislative process on the intellectual property law in Jamaica. He actually sat down with the local lawyers and wrote their copy right law together. The protection of intellectual property law had been one of sensitive issues over the negotiation of new international trade regime. It well represented the typology of the South-North disparity in terms of international economy. This new area, in terms of law implementation or imperialistic upstaging, could not be entirely pure provided if the issue entails a genuine aspect of contention and they apply an implied thwart to comply with their theme or values. The kind of undue influence from the private sector, as represented publicly by the USTR or other trade agencies, could not come in comport with the traditional notion of state sovereignty, in this contemporary age, largely not from the military might but from the negotiation and implanting their legal system or value (Harrington, C. B. \& Carter, L. H. , 2009). The other critique stresses its possible contribution to fuel a trade warring. As we consider, the scope and ways to identify the Priority Watch List and Watch list, for example, between 1996 and 2000 could be biased or compulsory to remove the essential attribute of public administration, some leniency with an interpretive leeway or authority to determine the fact. Based on the facts determined by USTR, the normal ways of public administration should anticipate that the PWL may not be prepared. That is not the case in these rules, which subjects the independent constitutional authority unduly under the control of US Congress (Bowers, J. R., 1989). The essential function, namely "execute the laws," enshrined in the constitution was affected seriously by depriving the power to withhold an execution on the construing of statutory requirement and fact determination. Practically, the statutory standard or rules, such as discriminatory, unfair or unreasonable, would not govern, but merely be hyped or framed, if to produce as mandatory the countries of unlawful or unfair practice annually. Therefore, in this case, the separation of powers principle, "hermetically sealed, but identifiable in its very attributes," could ebb in the dubious interest of collaboration and cooperation as furnaces into one of priority national goals. The role of president, thus, would be fairly open and positive to structure this distinct policy area. From the kind of immediacy, readiness and emergency as a character for this area of laws and public policy, it would be plausible to make the laws to effect only in short time limitations, and delegated the power to renew within the hands of President (Gibson, M.L., 2000).

Hence the role of President would be excessive to make the whole of system fatal, which would not be a normal way in the plain administrative issues. This moderates the imagery of "executing legislature" and divulges a distinct paradigm of national trade administration, as corroborated in the fast track procedure to enact the trade laws rules. The role of president would be heavier since the industry would be any most enabling constituent to mobilize his political support. Institutionally, the machination of bureaucracy is tightened and condensed, and could go on the same tone and spirit since the issues involve an applied concept or strategic decision than the normal consideration of laws and public policy. As reiterated, the quality would require an immediacy and strategic leniency beyond the normal extent of interpretive leniency (Bowers, J. R., 1989). For example, the President and USTR have to respond with an adequate retaliatory measure which is highly susceptible to a negotiation and as fairly undefined in extent unlike the administrative fines or cease and desist order. Of course, the leadership of President would become more salient under these policy environments. Then it would not surprise that the vision of President was shaped in 
terms and put to the public notice through the website of USTR. The annual report also begins with the President vision and summarize their achievements and tasks on progress in line with the vantage of his emphasis. The President's and congressional role could be ascertained in the TPA program, in terms of collaboration with the Congress and under the constitutional structure of trade policy making (Great Neck Publishing, 2009; MacDonald, J. A., \& Franko, W. W., Jr., 2007). A TPA or TPA legislation would denote the acts or statutes framed since 1974, which defined the U.S. negotiating objective and priorities for the trade agreements and established a consultation and notification requirements for the President. It is subject to the approval of Congress and reaffirms the primary role of Congress in the development and oversight of U.S. trade policy. Its key elements incorporated the levels of congressional authority from its role of guidance, establishment of congressional requirements, through the terms, conditions and procedures of negotiated international trade agreements (Bowers, J. R., 1989). The notification and consultation with the stakeholders come as important, and the power of purse would be an effective tool to achieve a congressional intent. A procedural requirement for the consideration of bills to implement the trade agreements is not unexpected with the recent tendency of strong oversight mechanism. The stakeholder's approach including the Congress, private sector, the public and other stakeholders would demonstrate a legitimacy and democratic concept of constitutional play or public administration (Great Neck Publishing, 2009; MacDonald, J. A., \& Franko, W. W., Jr., 2007).

\section{Transition of Presidency and Its Influence}

The transition from one presidency to another, particularly a shift of partisan administration would incur largely similar consequence, such as midnight regulation and often unfriendly reaction from the succeeding administration (Brito, J. \& De Rugy, V., 2009; Sapien, J. \& Nankin, J., 2008). Some characteristics in the trade policy and its administration would expose in aspects. First, since the trade policy is retrenched with key national agendas, such as economic growth or fiscal and trade deficit, the partisan politics would less be a decisive factor in the rulemaking and implementation of laws and trade policy. Second, the stakeholders would be major businesses and industries which entertain a strong voice in the national politics. They often interact effectively in the web of policy networks and key financial supporters for the federal election. They are highly powerful to inform or inculcate the bureaus in order to promote the national trade interest. This generally works to arouse the focus and attention of new administration. Nevertheless, the same general nature of trade issues would mitigate the chances of paradigm shift in the policy-making (Gibson, M.L., 2000). For example, the Bush administration and Obama's would share the value of liberal market and the safeguard from the unlawful or unfair practice of foreign nations would be an urgent national priority. According to Ambassador Zoellik, a removal of trade barriers in foreign markets along with the domestic liberalization would be a central concern in the Bush administration. He further stressed to fulfill the President's vision for 2001 " to reestablish a bipartisan consensus on free trade and to move on multiple fronts to expand trade” (2000). Third, a sharing and common recognition between two administrations, however, could be vitiated from its effect on the domestic issues. For example, some sectors of workers may disfavor an FTA because of its adverse impact on their labor market. Auto industries might not be readily sanguine to conclude the FTA with South Korea since the tally and aftermath may show it would not entirely be beneficial. However, this never means that the trade policy should come as a midnight regulation or other distinct consequence in the transition period. Of course, that is because that the trade policy would not be unilaterally dealt, but requires a 
lengthy negotiation and international compromise. As noted, the Congress is a major player to ensure the interest of national industries. In the basic feature of TPA, we can confirm a multiple transformation from the external and internal factors, "TPA ensures transparency and public engagement in trade....makes trade agreements better.... helps to export more 'MADE IN AMERICA' products abroad....supports job growth.” Transparency and public engagement in trade simply reflect the new ethos of international trade regime and congressional role. The job growth would be a sensitive policy promise to be argued seriously by the new President (Samuels, D. J. \& Shugart, M. S., 2003). In short, the transition of presidency can be viewed in subtle differences, perhaps because of the attribute of trade policy. The oversight of trade policy needs to be made distinct, which would be from the same ground.

\section{The Challenges and Judicial Control}

The judicial oversight would intervene to respond with the challenges and agencies action in multiple dimension (Woolf, L. \& Jowell, J., 1995). First, the USTR would interact and ne infused by the WTO dispute settlement mechanism. It is interesting, however, that the status of US would be preeminent in the international community and the WTO would not be a definite authority unlike the national court. The national courts would control in our most sensibility, but the WTO would be external to communicate, negotiate, be informed and respond. That is not merely a sensible matter, but also connoted in both of system and institution (Bailey, M. A. \& Maltzman, F., 2008). First, the decision of DSB takes a form of recommendation, neither order, declaratory, commanding nor injunctive to coerce its view. An intrinsic of binding effect as a norm would lack essentially notwithstanding its practical impact. However a disrepute and discredit from non-compliance might follow and, in some extreme possibilities, they may be dismembered from the WTO. Nonetheless, it would not be a presidential command to penetrate the line authority of agencies nor the court order enforceable upon the state power. For example, the court order to remove the life support system for the patients in a vegetative state in Florida could not be abrogated by the resolution or order of Governor. On the while, the WTO decision of panels or appellate body would basically depend on the national strategy and value whether to comply or not. The only recourse in this case would be a finely prepared retaliatory measure permitted to the winning party and compensation settlement in proportion with the alleged breach of WTO laws. Nonetheless, the US and EU would be a major power to engineer this international organization in terms of the economic scale and legal intelligence. Its paradigm would be based on two western legal traditions, and in some cases inculcate its developmental path for a new treaty or multinational trade agreement (Clark, B. R., 2003). They would be the kind of "economic chess board," for two major powers in an extreme sense, and also for other reasons, such as its location, staffing, its function, etc. and as we see Greenroom practice. However, it is true that the normative system is conspicuous, typically since 1995 and as radically reformed with the new dispute settlement mechanism. This means that the US and EU may be prime progenitors of this institution, but should learn from their protégé toward the idealistic trade regime of world. In this aspect, the concept of learning organization and acculturation of organizational members often proposed by the theorists of governance could be attributed to the relation of multiple actors involved in the international and national trade policy-making. Second, the USTR would undertake a role to respond with the international scale of challenges, and the extra-territorial application of domestic laws would be contended as a matter of legal theory. The Courts often would be a faithful executor to apply the national 
laws as possible extent, but not in conflict with their legal frame and beliefs (Bailey, M. A. \& Maltzman, F., 2008). In this light, the Court would be a collaborator with the USTR to forge their national interest, yet it being generally less pursued by the Court other than the USTR. This might be because the Court would be more strictly bound by the laws and legal theories. For example, the USTR would be more spiritual or enthusiastic to regulate an infringement with the trademark, but the Court would moderate on the effect theory. Third, the trade administration in the US would be perceived in two classes, which are more norm-based on one hand and are more strategy-oriented on the other. For example, the anti-dumping and subsidies measure or countervailing tariffs would be disposed on the fine system of statutes or case laws while the Super and Special 301 as well as safeguard measure would require a presidential mind and engagement in the organizational structure and would incur less a chance to be brought into the litigation (King, K. L. \& Meernik, J., 1999). Interestingly, we can know a strategic primacy of trade issues with one illustration, so-called the Byrd Amendment. The anti-dumping and subsidies measure basically has been punitive and in order for the sanction of unfair competition, but could be schemed to benefit the domestic industries from the income of anti-dumping or countervailing tariffs. This perversion was disputed in the Court, and condemned partially by it, but on other ground. The international context of trade justice or ideals would not be a direct point on which the national courts could base his determination (Shapiro, S. A., \& Levy, R. E., 1995). Rather, equal distribution, other than finding of subsidies, injuries to the domestic industry, and fair competition, must be attracted and focused from the constitutional viewpoint. The Byrd case certainly could undergird the characteristics of trade policy from other policy areas of more domestic aura. I may consider additionally two specific challenges involving the Super 301 and extraterritorial application of national laws.

In the Banana and Hormone case, EU was illustrated as one of priority watch list by the USTR and the EU initiated an action to claim that Super 301 (301-310 officially) would violate the WTO laws. The claim raised several points of aggrievance. First, the time frame of US trade acts is not proper as short for a finding and retaliatory measure that the US could not respect the WTO opinions and decision perhaps lengthier in process. This would cripple the dispute settlement system of WTO since the US could not fully wait until the WTO decision comes out. Second, the trade acts confer an authority to determine a trade violation on the USTR, as spelled out "unlawful, unfair or discriminatory,... deny the trade interests and privileges of US duly entitled with the international laws...” In this assertion, EU emphasized that the USTR would not be an international arbiter of international laws (King, K. L. \& Meernik, J., 1999). But it could be countered that every national agency could learn the international laws and impose their views and public policies within the territoriality principle. EU eventually argued that the frame is inconsistent with the DSU provisions. Third, the trade acts would contravene the basic spirit and structure of WTO and DSU which is directed not for unilateralism, but for the multilateralism. The panel report was adopted (WT/DS152/R) with the approval of DSB, and EU discarded an option of appeal to cease the controversy. The panel report clarified that the trade acts are weakly framed in high possibilities of threat, which are to allow the USTR a unilateral and arbitrary coercion. This would be a prima facie violation of DSU. However, in consideration of the trade acts and other factors, typically the measures undertaken by USTR over time and history as accorded with the congressional direction, the Super 301 is not deemed inconsistent with the US commitment of the WTO laws. The panel added a precaution that the future of USTR's policy may jeopardize a contrary result unless it must otherwise be in comport with this decision. A criticism to favor 
the US position could not be negated. The alleged conviction of USTR would well be based on its finding that the odd countries or practices violated the international laws. Super 301 could be supported as a domestic policy tool upon the petition of stakeholders and based on the intrinsic of state role to protect their citizens' interest. The previous cases would merely implement the WTO rules which would be a part of international laws in the province of case law tradition. This point, however, may be argued if the WTO would merely be a foreign judiciary. Still the cases of other common law countries would be an influential authority, if not binding as in a strict terminology. In any case, there would be no basis of good argument to debase the previous practices of USTR. Super 301 is not a monstrous institution, but merely delegated the trade authority to the President of US. The Super 301 is managed largely in the discretionary scheme of USTR, and the failure to exercise a due extent of discretion would not be an international matter, but merely national, which would still be dubious if the national courts could intervene. A critical point lies in the question whether the President actually violate the international laws in the enforcement of Super 301, not whether the system could allow a possibility to violate the international laws (Kirwan, K. A., 1995; Rosenbloom, D. H., 1983). Super 301 would be positively evaluated in other points of view that it could contribute to the holistic picture of justice in the interest of international trade regime. Assume if the worse countries in the trade commitment may respect the finding of USTR and withdraw from their breach or discriminatory practice. Then, the market access and ideals of transparency may be elevated. A normative view can also make it distinguished between the violation of international laws and unfair or discriminatory practice against the trade interest of US (Bailey, M. A. \& Maltzman, F., 2008). Still we could not find any legitimate ground to coerce abandoning the national policies to protect from the latter class of worse practice. As a state theory and international laws, the governmental role to promote the general welfare and sovereignty of domestic policy making would be sacred and inviolable.

\section{Trade Administrators and Leadership}

As with the normal area of public policy, trade administrators are required to consider the laws and create the rules or public policy. Hence, while a political control, for example, via RPO or other name of political appointees would figure to affect the administration, the normative aspect has to be powerful as a variable. A bureaucratic sociology is also another factor which intervenes to reach the final shape of trade policy (Gajduschek, G., 2003; Kauffman, H., 2008). One of traits in the USTR and trade policy would be obvious that the international laws, centrally on the WTO and FTAs, would be an important law they have to be consistent to interact. The bureaucrats in trade administration, therefore, would often possess a talent or career experience as a diplomat. A share of officers would study the foreign relations in the university and the current head of USTR would not be an exception. Michael Fromm, a current leader of organization, officially shingles his biography as a diplomat in the webpage of USTR. He is also a close friend of Obama, a graduate of Harvard law school, while attending the JD program there. It signifies the spoils system of US administration, and the importance of political control to respond with the theme, "democratic rule and check mechanism." He is the kind of political appointee who is responsible to implement the popular will as represented by the winning candidate of presidential election. Still the continuum of national administration, however, may be resilient which often counteracts with a complete or perfect alternation of paradigm or past policies (2003). So the sociological aspect would come third in factor which follows the economic and political paradigm. The rational choice theory might come idealistic as first, 
and entered into a phase, and perhaps influences an ambitious wish of succeeding president. He may feel underwritten by winning the election whose policy would realistically, if not mere in theory in this stage, most rational and desirable by majority of voters. The administrative world makes a third phase possibly to muddy the vision on one hand. Meanwhile, the staffs and administrators could aid to make it tangible or more reduced to be vital for implementation on the other which we expect idealistically. In this perception, the bureaucrats might be a working arm of presidency through the machinations of administrative branch, but also comprises a distinct society on history and tradition, expertise, experience, as well as elements of humanity (Kauffman, H., 2008). One helpful illustration would be Hoover who was an FBI director to play on six presidents of United States. A formality in the line command and supervision in combination with the political will of people would certainly be in any primacy, but the kind of rare stories would divulge the informal aspect of bureaucracy, perhaps human or organization-specific contingencies. The USTR would entail the kind of normal characteristic in the assessment of head roles. In addition, we can derive points in distinction from other agencies. The USTR historically is not traditional if it was created as late as in the 1960's Kennedy administration. Its scope and quality of authority would shift to strengthen itself and in an intimate interaction with the President and Congress. For example, the negotiation and sanction initially were elective within the discretion of agency. Afterwards, it turned to be mandatory in response with the aggravated trade or fiscal deficit. This implies that the trade policy would be strategic and demanding issues of nation where the head roles would be consistent and vigilant in a direct reporting to the President and Congress. Often diplomacy or negotiation would be more friendly with the politics sensibly, which gives a space from the normative orthodoxy. Hence, the political role of agency's head would be stark although its scope of command may not be extended. This can lead to the organization more qualified, alerted, readier and capable as a whole. The flavor of "economic FBI or CIA" would not be false to view the USTR. The trade issues had been intensified over the increasing rate of internationalization, typically beginning at the creation of new world economic order, 1947 GATT and Bretton Woods Conference. The 1947 GATT witnessed eight Rounds to discuss the major issues of world trade, and President Kennedy had achieved an impressive success in lowering the tariff rate. Around the time, the US hegemony politically rose, and the international policy was expedited. The trade administration turned to be marshaled and in some comprehensive structure through the 1980's omnibus laws. In this nature of organic history, USTR would be a one of star agencies to testify a US commitment to the international community. The head role would be significant not only nationally but also internationally. The normal aspect of internal oversight would not be waived, however, which evinces the importance of democratic control (Gajduschek, G., 2003). It would be responsible to the parent agency, EOP, currently led by Denis McDough as chief of staff. The EOP would consist of various public offices to aid the presidency, to illustrate, the Council of Economic Advisers, Chair of the Council of Economic Advisers, Chair of the Council on Environmental Quality: Office of Management and Administration[edit]Office of Management and Budget: Office of National Drug Control Policy: Office of Science and Technology Policy,Office of the United States Trade Representative, Domestic Policy Council, and etc.

\section{The Role of Mass Media and Trade Policy-Making}

The role of mass media is extensive to affect the law and public policy. The implications from this interaction would be conceived both positively and negatively in view 
of idealistic process in democracies. For example, the agenda setting theory holds a view, based on the empirical study covering 1968 presidential election, that a frequency and prominence in the news coverage determined a most important election issue. For example, Cook et al suggested that the media influenced views about issue importance among the general public and government policy makers, who used an experimental design built around a single media event (Cook, F. L., Tyler, T. R., Goetz, E. G., Gordon, M. T., Protess, D., Leff, D. R., et al. 1983). The limitations of media also are alleged to be present. The conflict laden exposure of public issues in the news or television program can have a potential of misleading the public opinion (Forgette, R. \& Morris, J. S., 2006). An odd simplification and strategic framing can make it a kind of contact sports lacking prudence and contemplation. The intrinsic of mass media as commercial establishments and professionalism would make a high social impact, but nevertheless comes short or contingent on a day to day basis. The news reports may be matched with a parliamentary debate for our comparative purpose in effecting to transform the society (1998). Basically, we may hardly construct the news source or information readily on its own, which is thought as, "no politics possible at the speed of light” (1998). In this standpoint of view, the trade policy is generally fact-driven in the treatment of media, and the multifaceted and mosaic of policy factors requires a more strategic ways of approach with the professional aids and expertise. That is true indeed as compared to other areas of public policy, including the public health, social welfare, or criminal policies. The issue tend to involve a kind of conundrum which encompass widely, the field of law and treaty, diplomacy, global economy, and industrial condition. Nonetheless, the strategic framing of media may expedite the profiling of issue and contention of issues, for example, the auto sales market between the US and Japanese producers. This could affect that the trade administrations, DOC or ITC and USTR, may motivate themselves to act and investigate the issue.

Mass media generally is attributed as "fourth branch," which plays an important role to engineer the democratic society. They lead a public opinion and frontier the new development of issues, events and occurrences. They are a vanguard to situate the community through the past, present and future context of meaningful construction (1998). They are a center of public attention, and mobilize the basis of policy environment. Their impact would be serious to move the policy makers since they have to be accountable for the popular will. The impact of mass media on trade administration should not be overstated, and they actually orienteer a public opinion in safeguarding the accountability of government. They generally function to aid in setting a most important trade agenda and can facilitate shaping issue importance in the trade policy area. They also undergird the direction of trade policies and help to create an alternative. Nonetheless, the ultimate responsibility remains with the law or policy makers because (i) they are politically elected and assigned a power and competence to create or enforce the public policy (ii) we have no way only but to resolve a public issue or agenda, which is on a continued study and churning, sees it as enduring issue, and renders it as informed, systemic, monitored, prudent as cost-benefit analysis, procedural, and some form of participation.

\section{Reference}

Bailey, M. A. \& Maltzman, F. (2008). Does legal doctrine matter? Unpacking law and policy preferences on the U.S. Supreme Court. American Political Science Review, 102(3), 369-384. 
Bowers, J. R. (1989). Agency responsiveness to the legislative oversight of administrative rulemaking: A case study of rules review in the Illinois General Assembly. The American Review of Public Administration, 19(3), 217-231.

Brito, J. \& De Rugy, V. (2009). Midnight regulations and regulatory review. Administrative Law Review, 61(1), 163-197.

Chung, J.W. (2006). The Political Economy of International Trade: U.S. Trade Laws, Policy, and Social Cost Lanham \& Oxford. MD: Lexington Books.

Clark, B. R. (2003). The supremacy clause as a constraint on federal power. George Washington Law Review, 71.

Cook, F. L., Tyler, T. R., Goetz, E. G., Gordon, M. T., Protess, D., Leff, D. R., et al. (1983). Media and agenda setting: Effects on the public, interest group leaders, policy makers, and policy. Public Opinion Quarterly, 47,16-35.

Forgette, R. \& Morris, J. S. (2006). High-conflict television news and public opinion. Political Research Quarterly, 59(3), 447-456.

Gajduschek, G. (2003). Bureaucracy: Is it efficient? Is it not? Is that the question?: Uncertainty reduction: An ignored element of bureaucratic rationality. Administration \& Society, 34(6), 700-723.

Gibson, M.L. (2000). Conflict Amid Consensus in American Trade Policy (American Governance and Public Policy series). D.C. USA: Georgetown University Press.

Great Neck Publishing (2009). The Constitution of the United States 1787, Great Neck Publishing, 18.

Hammond, T. H. \& Knott, J. H. (1999). Political institutions, public management, and policy choice. Journal of Public Administration Research \& Theory, 9(1), 33-85

Harrington, C. B. \& Carter, L. H. (2009). Administrative law and politics: Cases and comments (4th ed.). Washington, DC: CQ Press.

Iancu, B. (2012). Legislative Delegation: The Erosion of Normative Limits in Modern Constitutionalism . Heidelberg \& New York, FRG : Springer.

Kauffman, H. (2008). Ruminations on the study of American public bureaucracies. The American Review of Public Administration, 38(3), 256-263.

Kerwin, C. M. \& Furlong, S.R., (2011). Rulemaking: How government agencies write law and make policy (4th ed.). Washington, DC: CQ Press.

King, K. L. \& Meernik, J. (1999). The Supreme Court and the powers of the executive: The adjudication of foreign policy. Political Research Quarterly, 52(4), 801-804.

Kirwan, K. A. (1995). The use and abuse of power: The Supreme Court and separation of powers. The Annals of the American Academy of Political and Social Science, 537(1), 76-84. Available Here.

Laureate Education, Inc. (Executive Producer). (2009). Fundamentals of law and public policy: Administrative agencies - Authority and enforcement. Baltimore: Author.

MacDonald, J. A., \& Franko, W. W., Jr. (2007). Bureaucratic capacity and bureaucratic discretion: Does Congress tie policy authority to performance? American Politics and Research, 35(6), 790-807.

Patterson, T. E. (1998). Time and news: The media's limitations as an instrument of democracy. International Political Science Review, 19(1), 55-67

Rosenbloom, D. H. (1983). Public administrative theory and the separation of powers. Public Administration Review, 43(3), 219-227.

Samuels, D. J. \& Shugart, M. S. (2003). Presidentialism, elections and representations. Journal of Theoretical Politics, 15(1), 33-60.

Sapien, J. \& Nankin, J. (2008, November 18). Midnight regulations. Retrieved from 
http://www.propublica.org/special/midnight-regulations

Shapiro, S. A., \& Levy, R. E., (1995, April). Judicial incentives and indeterminacy in substantive review of administrative decisions. Duke Law Journal, 44(6), 1051-1080.

Woolf, L. \& Jowell, J. (1995). Judicial Review of Administrative Action, New York. NY: Thomson Professional Pub Cn. 


\section{Global Issues and Public Policy}

\section{International Relations and Domestic Jurisdiction}

In our learning, the public policy certainly is the idea of "professional humans or organizations," which is consequential through the institutions, system, event, occurrence and in turn, over history and time period, learning and lesson. Then, it shows, in an extent, a pattern within the autonomous cycle in circular and in the kind of self-perfection given we leave from the subject matters and see purely its forms of cycle. The public policy, in elements, may presume several aspects in my personal view.

First, the concept is neighborly to be matched up with the issues or controversies. Industrial complaints concerning the unfair practice of Japanese semi-conductor perhaps indicate some issues underlying to be resolved for the national interest and ideals of fair trade. The Iraqi war provoked a serious global controversy about the peace, security, and prevention of wars and aggression. Second, the public policy is a hybrid of consequence which is influenced by the elements of other discipline. As it is generated by the officers or agencies, the variants are highly interdisciplinary, which cover the philosophy, psychology, politics, economics, sociology as well as law. An in depth studies in the interest of specific policy making or others may be motivated and designed to illuminate what factors are most determinative leading to that specific outcome. For example, the response of US government to the Iraqi invasion may be explained by the realist lens, which is primate within the department of political science (Cortell, A., \& Davis, J., Jr., 1996). They may raise a hidden hand of oil politics if the region would be strategically crucial in that aspect. They also support the version that a late action of Reagan Administration between the 1982 and 1986 would be plausible if the market dominance would not threat the hegemony of US semiconductors until 1986. The interbranch analysis may be elicited in light of law and bureaucratic sociology where the formality of law and personality of key officers generally are perceived as most influential. The thesis investigated by Cortell \& Davis illustrates a wider view in response with the international issues and domestic policy-making (1996). They argued that two strands are fairly determinative to frame a most plausible account of policy making in the international relations. They found that the "domestic salience of norms" and "domestic structural context" within which the policy debate transpires have to be keyed in looking to any most precise construction between the specific global issues and domestic response.

They applied a "process tracing” to two global issues in the 1980's and 1990's in the elaboration of their thesis (1996). It opens up a width of factors to affect a policy outcome. If it employs the word "salient," it entails a personal or organizational attribute partially which is psychological or philosophical. For some, the environmental issue would be more implored than the developmentalists' philosophy. For others, his personal philosophy may dispose himself that the war and aggression is a matter of state sovereignty, typically if the cause and justness only could be subjectively defined and if a veto is essential to shape the current international politics in the UN. Then it would get better to be distanced from engagement. On the other hand, the economic issues are universal and can have a good standard to make us more intense in seeking a fairness and agreeable level playing field. This view might counter-pose the assumption of above authors, instead, as pointed in the purpose of wider variables about the policy making. Perhaps the view may be shared if we consider the second 
of major powers other than US, which are mostly a group of western industrial states. Given the international politics are considered either bipolar or tri-polar and said of new cold war, the understanding might come more complicated. The view also is institutional, perhaps legal if more hard, and interconnected into a most of concern approached by the disciplines of social science. The "salient" in the above two authors' case might be framed "socially" other than "personally or organizationally" which depends on the custom or convention of nation, perhaps, a specificity of domestic politics. The "domestic structure” also begins comprehensively with the party politics, attributes of mass media, national culture or ethnic and racial sociology, through the economic status of nation, and might encompass a hard nature of decision making process, for example, the Constitution and statutes.

\section{From the Types of Nations through the Global Village}

One of global issues to address the relationship with a domestic policy making is how much Korean public had to pursue 1988 Seoul Olympic. In the thought, I consider that it would divulge a "salience of strategy" more in characteristic than "salience of norm." I once discussed that the contemporary humanity or organizations could be shed, in some dimension, as nearly strategic animal. The assumption seems to be fairly apposite for the national context of policy making to address its international relations. Given the power of nation-oriented account as generally common, the extent and consequence involving the international relations might differ depending on the status of nation and policy environment(Shiraev, E.B., Zubok, V.M., 2012). For example, a hegemonic nation may be pushed more to act in the initiative or cause than national interests. A development of policy response against the Iraqi invasion might be viewed that a global quest about the adequate sanction may enmesh the Bush administration into keeping on their commitment of collective security. I made a point that the developmental states generally show a propensity of strategic focus more amply in the pursuit of national interest. They would generally be simple to grow and increase a material base of national capabilities where the policy makers and head of administration often had been impressive. Chun and Noh in the 1980-1990's Korean democracy, the leadership of China over the recent decades, and eminent international politicians in the countries of Third World often are considered effective to develop their nation. In the wake of policy pursuit, the high likelihood would be trigger a symbolic event to forge an imagery of their nation in the international community. The kind of "salience of strategy" requires a holistic system of national administration and in collaboration of private stakeholders, which would be for competing to attain a host-ship of significant international events. This synopsis is highly relevant in the endeavor of Korean leadership in 1988. In the time period, Korean economy had grown and began to be seen as a newly developed economy, and the international role or imagery turned to make it shoulder on shoulder with the developed group. The kind of symbolism might well be embraced for the key officers in South Korea (2012). The leadership was based on the militaristic background, and would perhaps be highly effective to organize the national energy and system to such direction. Under this environment and national mood, the policy makers of South Korea eventually prevailed over other competitors as successful if to hear an official announcement, "Seoul for the 1988 Olympic Event.” This kind of cultural politics may not be nugatory for the domestic policy makers to deal with the international variables. The dynamic often can be connected with the diverse interests and concern, but on some conditions, a symbolic effect could be paramount outflanking the economic math or key frames of domestic policy making standard. Hence, the agencies and officers, in dealing with the global issues and policy making, need to have a 
talent to appreciate the essences involved. In this case, a good mind exposed to the philosophy of symbolism may expedite a policy process and help to explore a policy option.

One other example may be found in the Nobel Prize and other international honors. For the Nobel Prize, Sweden can improve a state image in the international relations which would perhaps have to remain a small of European states. The aftermath of atrocities from many wars would be importantly consequential and let them highly disappointed. An idea of Nobel Prize would seem to invigorate the vigor of global public and inspired a new horizon of subsistence and human direction. At the end of two world wars, European construction had been pursued that the countries destroyed during the wars create their new stage through the EU (2012). The policy of Nobel Prize is now considered most successful and as symbolic to represent a human wisdom and world peace, One similar nature of policy idea may be shared in the today's news that the British government pledged to compensate for a successful person at the tremendous amount of prize money, so-called "longitudinal prize." It posited six fundamental global issues as a query to be solved, which are paralysis, antibiotics, dementia, water, food, and flight. To specify, the candidates for the prize has to solve six questions. For example, he or she needs to answer in any systemic way, "How can we fly without damaging the environment?"

A tendency in response with the global issues and in concern of the international relations seems to be particular and depending on the characteristic of nation. Noble and politically waned countries generally tend to appreciate on the kind of symbolism and cultural impression. The strands seem to be in comparison with the political, economic and normative approach, perhaps from the US. France, generally considered an antedated power in the old age and as a progeny of the Roman Empire, now has been occupied that the administrators are endeavoring on how to exploit their cultural assets in the interest of national economy. The public officers in France may be skewed how to draw a maximum profit from the travelers of Louvre. A succeeding power from the old age, Britain, would tend to apply a cultural or intellectual and globally social lens than the law, politics and economics. British administrators may prefer a "global village" than the "US politics" or "UN based international relations," which may be more sociology-oriented or cultural. They may symbolize a trade of slave to make them realistic in history, but it would be extremely antedated that the global narrative may get it more significant if the Carr's neorealist view be finely focused on the European history and new proper dealings within the limit of European reality (2012). Given this condition, global issues would flow as symbolic and contingent where the domestic policy makers need to have a point. This basic awareness of domestic policy makers on the status and condition of nations may convert them as a strategist which was my argument elsewhere. The examples also illustrate an importance of policy network provided if the government can make a good deal with non-profit organizations and collaborate to establish the prizes.

\section{From the Nation through Global Jurisdiction}

My hypothesis then may lead to the tendency that the US, an alleged hegemony in the international relations, may be disposed more in frame with the normative, political and economic concern (Hudson, D., Rosson, C. P., Robinson, J. \& Malaga, J., 2005). That would not be incorrect generally so that the legitimacy of collective security was contended in view of the approval from the UN Security Council. The constitutional scholars also consider that issue in the same frame of concern. One other example shows an economic primacy in 
affecting the policy outcome or exploring alternatives for the future basis of policy making. The issue contrasted with a drug spending and generation of income for the domestic pharmaceutical industries of US (Lakdawalla, D. N., Goldman, D. P., Michaud, P., Sood, N., Lempert, R., Cong, Z., et al., 2008). The study guides a generally higher spending of US consumers on drug which has led some U.S. policymakers to call for limits on U.S. pharmaceutical spending and prices. The research findings suggest that price controls generate modest benefits, but price controls also generate costs that are an order of magnitude higher. It may contrast that publicly financing reductions in consumer prices, without affecting manufacturer prices, delivers benefits most certainly (2008). The health issue would be global on one hand, but the policy makers may get more interested in its impact on the industry as well as the decent standard of health. The economic narrative has a share of genuine elements in making the health policy. Given the international influence of US pharmaceutical industry, the findings perhaps can offer a paradigm of health policy shaping in other countries and help to create a point and concern in the international organization, notably the WHO. One other example illustrates the domestic policy attitude of three recent administrations in the US, which deals with the environmental issue and is seen as not consistent (Harris, P. G., 2009). The partisan politics or domestic context of democratic process is rather salient in this case, which is to make a reversed impact from the national politics onto the international relations. The consequence may be an international criticism and lacking administration without the participation of main player in the issue.

\section{Some Implications}

Over the description, I have explored a contour of domestic policy making in concerns of the global issues or interconnected dynamic with the international relations. Generally, the concept of strategy or stragetum, would be more encompassing to give an account of policy behaviors of nation. The domestic condition would be more salient to influence a shaping of specific policy than the international demand. For example, the desire to be reelected for the presidency may be any most dominant factor, in which the international issues would be left secondary and even to manipulate for less capture or critiquing. Nevertheless, the extent would differ given that an international commitment or institution is conventional or customary, for example, the role of US in keeping for the international peace regime. The policy makers often act on the law and regulations, but the admired policy would be conditioned on their quality to appreciate the subtleties.

\section{Reference}

Cortell, A., \& Davis, J., Jr. (1996). How do international institutions matter? The domestic impact of international rules and norms. International Studies Quarterly, 40(4), 451.

Harris, P. G. (2009). Beyond Bush: Environmental politics and the prospects for U.S. climate policy. Energy Policy, 37(3), 966-971.

Hudson, D., Rosson, C. P., Robinson, J. \& Malaga, J. (2005). The WTO cotton case and U.S. domestic policy. Choices, 20(2), 143-147.

Lakdawalla, D. N., Goldman, D. P., Michaud, P., Sood, N., Lempert, R., Cong, Z., et al. (2008). U.S. Pharmaceutical Policy in a Global Marketplace. Drug Spending, 28(1), 138-150. 
Laureate Education, Inc. (Executive Producer). (2009). Fundamentals of law and public policy: Global perspectives. Baltimore: Author.

Shiraev, E.B., Zubok, V.M. (2012). International Relations,Oxon. UK: Oxford University Press. 


\section{Collections of Correspondence: Sharing, Inquiries, Ideas and Suggestions}

\section{[Week 1]}

Author: Shari Tewa Date: Tuesday, March 4, 2014 6:23:56 AM EST Subject: Shari Tewa RE: Discussion 1 - Week 1

The relationship between law and public policy can be described as a 'hand in glove' one. Harrington and Carter (2009, p.27), describes administrative law as the mechanism that controls governmental power given to administrative branches that "gives legitimacy and authority to state actions." It is important to note that there are four sets of laws that govern the behavior of administrators, regulatory, statutory, common and constitutional (Harrington, Carter, 2009, p.27).

Regulatory law, is as its name suggests, regulates how particular agencies operate focusing as Harrington, Carter (2009, p. 18) states on the procedural matters that arise out of non-compliance in areas of citizen complaints as in the case of Goldberg v. Kelly 397 U.S. 254 (1970) 6-3 where the court held that the district court was correct in its decision that procedural rules were followed to the letter and that due process was granted the litigants who were entitled to an oral hearing after termination of welfare benefits according to New York state law. (Harington, Carter, 2009, p. 39)

Statutory law addresses social conditions and problems (Harrington, Carter, 2009, p. 27). These laws are created by state legislatures and the Congress that are designed to protect the citizens from injustices or unfairness such as monopoly on industries or creating of agencies such as FEMA (Federal Emergency Management Act) that may be traced back to 1803 in the first Congressional Act that legislatively provided assistance to a New Hampshire town devastated by fire (fema.gov), whose mission is to "support our citizens and first responders to ensure as a nation that we work together, to build, sustain and improve... and mitigate all hazards.” (fema.gov) Statutes then for example, allow administrators to rescue those affected by natural disasters and to try to make them whole again.

Constitutional Law can be termed the operating manual for the United States government. It also lays down the rules by which citizens must live in order to maintain an orderly society. It can also be said to be what gives rise to the "rule of law" that "everyone must follow the law.” (uscis.gov) However the lion's share of Constitutional Authority goes to the Government and its distribution of powers, as in those that determine that the Congress has the power to coin money, the President being the Commander in chief of the military and powers not reserved by the Federal government will go to the states such as the maintaining of judicial branches that maintain law and order of the individual states. Under the Constitution's first amendment citizens have the right to engage in freedom of association and religion...(archives.gov)

The common law aspect of administrative adjudication derives from the days of English rule when there were no laws written in books and matters were decided according to the wisdom (or in some cases lack of) the judges and attorneys who reasoned according to their own sense of fairness and justice and rendered their decisions accordingly. Thus stare decisis was born where the holding in one case whether the decision was fair or not, became 
the rule to go by in all other cases where the issues were similar (Harrington, Carter, $2009 \mathrm{p}$. 28). The holding in Goldberg v. Kelly 397 U.S. 254 (1970) 6-3 (Harrington, Carte, 2009, p. 41) illustrates this where "the reasonableness of the government's action" was at issue and that its secrecy created an unfairness to an individual who claims that their rights are being violated.

\section{References:}

About the Agency. Retrieved from: http://www.fema.gov

Bill of Rights. Retrieved from: http://www.archives.gov

Civics history and government questions for the naturalization test. Retrieved from; http://www.uscis.gov

Harrington, C. B., \& Carter, L. H. (2009). Administrative law and politics: Cases and comments (4th ed.). Washington, DC: CQ Press.

Author: Deidre Hunter Date: Tuesday, March 4, 2014 7:40:36 AM EST Subject: RE: Discussion 1 - Week 1

Public policy primary objective is to make and analyze governmental decisions. According to Harrington \& Carter (2009) the four basic laws includes the substantive and procedural rules the United States political system use to make legal rules. Therefore, public policy utilizes the 4 basic laws to help improve the public's problem, whether it is economically, socially or politically. For instance, in the media, there has been a lot of controversy over same sex marriage. Many people believe that prohibiting same sex marriages infringes on one of their constitutional rights, which has created a public problem and a call for a public policy. In some states, such as California, there have been laws put in place to allow same sex marriages in order to resolve the problem.

\section{Reference:}

Harrington, C. B., \& Carter, L. H. (2009). Administrative law and politics: Cases and comments (4th ed.). Washington, DC: CQ Press.

Author: Kiyoung Kim Date: Thursday, March 6, 2014 9:33:21 PM EST Subject: RE: Discussion 1 - Week 1

Hello. Deidre.

You pointed very incisively at the most sensitive public issue. The same sex marriage reveals the wider context of constitutional, statutory and public policy issues. Importantly, the problem is structured with the constitutional review of statutes. This would be a firm practice over history that the Supreme Court can annul an unconstitutional statute although no express language so delegated the power to the judicial branch. This raises a concern about its antimajoritarian difficulty against a majority rule. The latter is self-evident if we value a democratic understanding of national politics. The institution, in this sense, had been rooted 
in the distrust of politics. How much do you agree that the Supreme Court entertains a final say about the same sex marriage? If the local constituents largely abhor and dissent, is it acceptable that the SC sustain the validity of same sex marriage act? Thank you for the posting. Respectfully.

Thanks Kiyoung! Personally, I think the Supreme Court decisions plays a vital part in a laws and statues, new or old.

Author: Jessica Stanley Date: Thursday, March 6, 2014 10:01:42 PM EST Subject: RE: Stanley_Discussion 2 - Week 1

Harrington and Carter (2009) describe administrative law as a process of making policies of fairness and accuracy by correcting administrative government. This type of law limits the authority of the administrative agencies and creates legitimacy to state actions (Harrington and Carter, 2009). Administrative law is the check and balance of governing agencies by setting boundaries to those who serve the public. In other words, administrative law "regulates the regulators" (Harrington and Carter, 2009, p. 26).

Rulemaking is an important and time consuming process as it produces rules that are not always clear and understandable yet necessary. Kerwin and Furlong (2011) describes rulemaking as a refining principle that provides direction on many actions such as program implementation, procurement, conflict resolution, and personnel management. Rulemaking is a direct consequence of legislation proposed by the general public and enforced by governing agencies (Kerwin and Furlong, 2011).

Administrative law and rulemaking are necessary elements in public policy making. Public policies are public issues and concerns that are addressed by administrative agencies. These agencies, at any level, define the rules of operation that service the people. This rulemaking process is checked by administrative law for efficiency. For example, in my current profession as a license administrator for educational facilities, I witnessed several daycares being summoned to tribunals in the state of New York. These agencies serve the people and have their own processes and procedures. If inspected by the state or inclined to act because of several complaints, the administrative law will proceed with a rulemaking process on how the agency will continue to run in the future for safety, health, or environmental reasons. In conclusion, administrative law and rulemaking are distinct and vital roles in public policy making as it seeks to create and obtain effective policies for society.

\section{References}

Harrington, C. B. \& Carter, L. H. (2009). Administrative law and politics: Cases and comments (4th ed.). Washington, DC: CQ Press.

Kerwin, C.M. \& Furlong, S. R. (2011). Rulemaking: How government agencies write law and make policy $\left(4^{\text {th }}\right.$ ed.). Washington, D.C.: CQ Press.

Author: Kiyoung Kim Date: Thursday, March 6, 2014 7:09:19 AM EST Subject: RE: Discussion 2 - Week 1 


\section{Hi. Jessica,}

Thank you for the informative post. You said of "fairness and accuracy" that the policy makers should respect to service the people. The terms would highlight the rule of law ideals. The concept of republic entails, by ways of struggle, reform and self-correction, the elements of democratic virtue that the governments are to be based and respect. A liberty and equality would come front and the kind of proportionality principle needs to be ensured. The arbitrary public power certainly is an evil that the law and rule-makers have to avoid. You stated, "the agencies are inclined to act because of several complaints... the agencies began their rulemaking process for the future....” I am concerned, in that case, if they act equally between un-complained and complained facilities with same conditions. The concept of vested rights or license interests are one issue involved in the constitutional and administrative laws. I may ask if they take an impermissibly drastic measure against these concepts because they like to avoid a reprimand from the complaints? Respectfully.

Hi. Kiyoung.

Thank you for commenting on my discussion. You mentioned your fear that the agencies act equally between uncomplained and complained facilities. That is a fear of mine as well. From experience, some programs do just accept the low quality they are providing until administrative agencies reprimand their behavior. I think that is one of the powerful elements of administrative law is to correct the inappropriate and unproductive actions of programs that serve the public. With complaints being filed by parents in the daycares, for example, this lets your customers rate the company's product or service. This also allows administrative agencies to implement their corrective action which can come in the form of fines, provisional licenses, and possibly shutting the low quality program.

Best,

Jessica

Author: Thomas Stone Date: Thursday, March 6, 2014 10:33:08 PM EST Subject: Thomas Stone WK1 Disc 2 Initial Post

\section{Administrative Law}

Administrative law is a tool designed to regulate and amend administrative government policies. According to Harrington and Carter, political checks exercised in legislative and executive offices are another such mechanism (Pg. 27). Administrative law not only restricts the power of executive government; it also gives legality and authority to state actions. Administrative law is not actual rules, decisions and policies that administrators make, as Administrative law involves the process of creating policies and not the outcome.

\section{Rulemaking}

Unlike administrative law, rulemaking is a structure of rules by an administrative agency that is essential in a strategic procedure; created by statutes. According to Kerwin 
and Furlong, rulemaking defines the substance of public programs. Rulemaking gives precise form to the benefits we enjoy with the creation of a wide range of

statues. Rulemaking is important in the actions demonstrated through the conditions that American citizens' demand of the government. Rulemaking and the process of developing new rules holds someone accountable for the actions or changes to current or future programs or public policies.

\section{References:}

Harrington, C. B. \& Carter, L. H. (2009). Administrative law and politics: Cases and comments (4th ed.). Washington, DC: CQ Press.

Kerwin, C. M. \& Furlong, S.R., (2011). Rulemaking: How government agencies write law and make policy. Washington, DC: CQ Press.

Author: Kiyoung Kim Date: Saturday, March 8, 2014 1:58:34 AM EST Subject: RE: Thomas Stone WK1 Disc 2 Initial Post

Hello. Thomas,

Your point speaks at the core of two norms. I particularly see it means, "law is not actual rules, decisions and policies...holds someone accountable for the actions or changes..." This statement seems a decisive line between the administrative law and executive power. AL would be abstract, general, and principled while the role of executive branch comes at the end context of individual citizen. The rulemaking or implementation would generally be dispositive while the AL establishes a preserve of statutory requirement in the purpose to enable, regulate, and amend as you commented. With respect to this interplay, how do you consider two representative constitutional structures between the parliamentary and presidential system? Within the parliamentary system, do you think if two spheres could get more intimate and coherent since the parliament and cabinet work together? Thank you for the good posting. Respectfully.

Author: Michelle Early Date: Friday, March 7, 2014 12:33:08 PM EST Subject: Michelle Discussion 2 - Week 1

\section{Hello Class,}

Within the text Administrative Law and Politics, authors Harrington and Carter state that "administrative law seeks to reduce the tendency toward arbitrariness and unfairness in bureaucratic government (p. 2)." In short, this means that administrative law was created so that there would be some kind of checks and balance system for offering legal decisions. An example of this is seen in the fact that with administrative law, current cases can reference previous similar cases to provide a point of reference and render a similar decision. In rulemaking, rules are created to govern the people and this is done through the use of agencies. As defined in the text, Rulemaking: How Government Agencies Write Law and Make Policy. Rulemaking is the "direct consequence of the demands the American people make on the government (Kerwin \& Furlong, 2011)." 
In public policy making, administrative law and rulemaking serve as the foundational building blocks. Rulemaking ignites the notion that laws must be created and administrative adds to take, stating that laws can be formed for one area based on the formation of other similar laws. From here, public policy making can begin. These three items work simultaneously and jointly to further the progress of the American culture. Take for example the public policy agenda item of gun control. Gun control is an issue that the public is trying to contend with, currently. Past rulemaking has made certain actions with a gun illegal, including the murder or shooting of another. If one of the illegal actions with a gun occurs, administrative law can be used to determine the legal ramifications for that action. The three are heavily intertwined and rely heavily on one another.

\section{References}

Harrington, C. B. \& Carter, L. H. (2009). Administrative law and politics: Cases an comments (4th ed.). Washington, DC: CQ Press.

Kerwin, C. M. \& Furlong, S.R., (2011). Rulemaking: How government agencies write law and make policy (4th ed.). Washington, DC: CQ Press.

Author: Kiyoung Kim Date: Saturday, March 8, 2014 2:50:21 AM EST Subject: RE: Michelle Discussion 2 - Week 1

\section{Hello Michelle,}

I agree that the rulemaking is a direct consequence from the demands of American people. I consider that the rules a bureaucracy establishes would take several forms in its function and operation. Some rules purely are addressed to the internal matters of departments, bureaus, units and branches as well as the House or Senate. They may include the internal steps reaching to the final decree of bureaus or House. Those could be made distinct from other nature of rules if they do not directly reach out to touch on the rights or interests of American people. Against this scope of rules, do you consider if the citizens could make a claim that the internal rules are arbitrary or unfair against the concept of democratic process or other principles? In the Korean context, the political parties are bound to ensure a democratic selection for the candidates of public election. In that sense, the rulemaking power of political parties for the internal affairs are controlled according to the constitution and relevant acts. Nonetheless, the Korean court often refuses to review the constitutionality or legality of internal rules of bureaucracy. Respectfully.

\section{Hi Kiyoung.}

Thank you for your post! I think that there should be some ways of creating uniformity amongst laws that way they are not arbitrary. I think that this is why Administrative law exists- to create a uniform way of making decisions. And thank you for the information about the Korean process. 


\section{[Week 2]}

Author: Karen Davis Date: Sunday, March 16, 2014 6:26:23 PM EDT Subject: RE: Discussion - Week 2/Resp to Kiyoung Kim

How hi how are you? I enjoyed your post. You stated, "I consider that the judiciary and public agencies function in dual context; (i) independence in office and responsibilities (ii) check and balance. They are independent since the president is elected on a different basis of election." I agree with your statement fully. However do you believe that the judiciary branch should be only appointed by The president? Do you believe that the citizens of The United States should have a voice and become involved on who will be apart of the judiciary branch? If the judicial branch of government is keeping the executive branch in its place; who in turn will return the favor and ensure that the judiciary branch is kept in its place? Do you believe that most lower courts adhere to the laws that the federal court-The United States Supreme Court has set forth?

In your opinion do you believe that the judiciary branch of government is stronger now in present times or do you believe it was even more stronger in the past?

Finally, do you believe that the judiciary branch is the most important branch of the three?

Thank you.

Karen

Author: Melissa Rosa Date: Thursday, March 13, 2014 6:13:32 PM EDT Subject: RE: Discussion - Week 2

Congress enacted the Hatch-Waxman Act with two goals in mind: making generic drugs at a lower cost and creating an approval procedure for generic drugs along with extended patent protection for name brand companies. The courts were able to help develop a framework and introduce and recommend this to Congress. This act expedited the process of generic drugs being approved. As long as a generic company could prove that the generic drug was biologically and chemically the same as the name brand the drug could be approved faster. The name brand company is also allowed a period of exclusiveness to earn the initial benefits and profits from selling the drug because the name brand company was the company that performed all of the research, testing, and developing. This will also encourage name brand companies to invent more new drugs. The court suggested this to Congress to help regulate name brand and generic companies fairly. Public policy also favored the idea of generic drugs being provided that were more affordable to the people as soon as possible.

The Judicial Branch was created to handle disagreements over the law. The court can protect the rights of the people if the government is infringing upon them. Judicial review is the power of the courts to say that the constitution does not allow the government to do something by interpreting the law. The courts can also make suggestions to Congress to pass a law or create a law. The courts recommended the Hatch-Waxman Act to keep a balance in the pharmaceutical industry creating fairness between name brand companies and generic companies along with regulations. The court will be responsible for handling any of the patent infringement suits that come along with the law to protect the rights of the people. 
Barons-Pensabene, L., Gregory, D., Fitzpatrick, , Cella, , Harper, , \& Scinto, (2013). Hatchwaxman act: overview. Practical law publishing limited, Retrieved from http://www.fitzpatrickcella.com/DB6EDC/assets/files/News/Hatch-Waxman Act Overview lpensabene_dgregory.pdf

Jaquette, I. (2007). Merck kgaa v, integra lifeseiences i,. American journal of law and medicine, 3, 97-117. Retrieved from Merck KGaA v, Integra Lifeseiences I,

Author: Kiyoung Kim Date: Saturday, March 15, 2014 5:37:45 AM EDT Subject: RE: Discussion - Week 2

Hi. Melisa,

Thank you for the informative post. It seems that the Hatch-Waxman Act shows a competitive context of intellectual property right and its using companies. The due protection of intellectual properties would be one crucial theme. The thought seems come in opposite where one emphasizes its nature as a quasi-property and the other perceives in terms of the common asset for any readier public use. As it entails the difficult legal issues, the judicial knowledge would help the Congress on that Act. You said, "The court suggested this to Congress to help regulate name brand and generic companies fairly....” The court, however, is only competent to act within the constitutional structure, which generally confines with the case or controversy requirement. Can you explain if the Court engagement is permissible to interact with the political branches, or how the Act skillfully could avoid the kind of constitutional issue between two natures of branch? Respectfully.

\section{From Melissa}

The Hatch-Waxman Act was created after a dispute between companies in court after a generic drug was approved after a long wait. Before the regulations and guidelines there were not many generic drugs that people could afford. The generic company was then sued because of infringement rights. The court suggested better guidelines and regulations for these situations allowing fairness in the system between both companies. Congress agreed and then mandated the Hatch-Waxman Act. With the court interpreting the law, it is very helpful to Congress when new laws need to be put into place.

Author: Belinda Szerletich Date: Friday, March 14, 2014 9:09:28 PM EDT Subject: RE: Discussion - Week 2

The judicial branch plays an important part of the legal system. This branch embraces case law that involves both the state and federal courts. Harrington and Carter (2009) expressed the fact that the judicial branch of the government interprets their own powers. These powers influence the judges who make the decision regarding case law.

The court case selected for this discussion is Mistretta v. United States, 488 U.S. 361. In this case, Mistretta was indicted on three counts of cocaine sale, and questions arose when the Commission violated the separation of powers principle. Mistretta pleaded guilty to conspiracy to distribute and was sentenced to 18 months in prison. However, in the judicial branch was able to bind sentences together. Because of this case the United States Sentencing Reform Act of 1984, was introduced. 
The judicial branch has the power to create law and execute it through case law. According to Harrington and Carter (2009), decisions are made by judges and often set case law standards. Nevertheless, the U.S. Supreme Court has the right to uphold prior decisions or repeal past decision of case law. As in Mistretta, by pleading guilty, allows a judge to make the final decision without appeal rights.

\section{Reference:}

Harrington, C. B., \& Carter, L. H. (2009). Administrative law and politics: Cases and comments (4th ed.). Washington, DC: CQ Press.

Mistretta v. United States, 488 U.S. 361.

Author: Kiyoung Kim Date: Saturday, March 15, 2014 4:43:14 AM EDT Subject: RE: Discussion - Week 2

Hi. Belinda,

I agree that the Sentencing Reform Act involves a delicate public policy, particularly within the separation of powers principle. We consider that the statutes or provision of acts in same concern and scope of application would preempt the general standing of case laws. Some liquor act would provide to replace the traditional tort laws in purpose of addressing the social challenge, for instance, juvenile drunken drivers and high rate of traffic accident. Prior to the SRA, the judiciary could bind the sentences together. After the SRA, they might be shrewd and skilled to defend their preserve of case laws and prefer to get out of its reach in ways of sifting and winnowing on distinguishing. I may ask if you can say the higher sentences in any accumulative context would infringe with the criminal justice because of guilty pleading. Or do you think otherwise if an imposition of higher penalties could prevent the kind of socially dangerous crimes and restore a due extent of criminal justice for the perpetrators? The Sentencing Reform Act was introduced into Korea in aspiration of American ways of criminal justice. In the course of public debate on this institution, Korean intellectuals had been afraid if the Act may contravene the role and responsibilities of judiciary enshrined in the very language of Constitution. The criticism saw that an adjudicative leeway for the arbiters or jurors are essential in intrinsic, which, in this case, would be transgressed by the legislature. The general standard of sentencing guidelines would not be in comport with the judicial power, and could undermine the constitutional scheme of judicial independence. What are your thoughts? Respectfully.

Author: Belinda Szerletich Date: Saturday, March 15, 2014 7:49:37 PM EDT Subject: RE: Discussion - Week 2

Response to Kiyoung Kim

I would say majority of criminals would accept a plea bargain just to keep from receiving a harsher sentence. This also saves the cost of time and trouble for the courts and attorneys. From what I seen in Illinois courts when visited courtroom activity from past 
courses, many criminals will accept a plea simply because they if they go to trial they may end up getting a longer sentencing.

However in Mistretta case, it appeared to be a mild sentencing considering the crime committed. The courts have the power to decide on the sentencing and in this case it appeared plea bargain worked.

\section{Shari Tewa Discussion Week 2}

The role of the judicial branch of government according to the founding fathers is solely the resolution of disputes between two parties, in stark contrast to that of the legislative branches that write the laws that keep the nation orderly. The role of the judicial branch is specifically to "not engage in policymaking." (BeVier, 1994) The role of the judge is interpreting the rules as they stand, which is different form that of the legislative branch that has much room to play. The courts are constrained in their administration of the law, because they are bound by it. A case that illustrates the limitation of the judicial branch and the sometimes unintended consequences of its decisions is the Swann v Charlotte-Mecklenburg Board Of Education 402 U.S. 1 (1971) which was intended to facilitate school desegregation, but actually yielded the opposite result with its forced busing order which created an abandonment of the middle class enrollment in inner city public schools. (BeVier, 1994) This is partly a result of a judiciary that is bound by the facts as they are presented to them. They do not engage in research to filter that which is true from that which is false.

They are limited to reason the facts that are presented before them and nothing else. The same rules that are meant to protect sometimes in essence then becomes the noose which strangles.

\section{References}

Bevier, L.R., 1994. Judicial Restraint: An Argument from Institutional Design. Harvard Journal of Law \& Public Policy. Wntr.1994 Vol. 17-1.

\section{From Kiyoung Kim}

Thank you for the excellent posting. I also agree that the jurors are not to be engaged in policy-making. This classic perspective seems fairly neat to strike any confusion. I suppose that the justices also prefer to group them in this pure and sacred triadic. This purview would not be associable, however, with the general views that the contemporary judiciary is a key player in shaping any important public policies. Nonetheless, the original intent of constitutional drafters also would like to execute in this assumption. The article from Rosenbloom also corroborates that the Supreme Court justices often act and deicide massively from law other than policy preferences. An active or bigger judiciary seems unrealistic, and the judicial restraint practiced by the judiciary also comes into a fit with this assumption. How do you consider if any divisive line exists between the judicial activism and its passive attribute?

Author: Shari Tewa Date: Saturday, March 15, 2014 11:43:27 AM EDT Subject: Shari Tewa response to Kiyoung Kim RE: Shari Tewa RE: Discussion - Week 2 


\section{Good-day Kiyoung,}

Thank you for your kind comments. In an attempt to answer your question, I pose this: The line that exists, if it all does, between activism and restraint may be blurred for the precise reason that you stated, the decision to judge from the book rather than from the head, maybe this may stem from the fact that policies are created through political maneuvering, capital and big money interests and are arrived only after the maximum amount of money is collected in support of an idea not yet policy. The argument in favor of a "bigger judiciary" as you say may quickly fade when viewed against the backdrop of failings of the court in their obligations to protect the peoples' rights if the courts are unwilling to challenge their own limitations in the state system that they are sworn to uphold.

Again, thanks for engaging

Shari 


\section{[Week 3]}

Author: Alina Titievskaya Date: Wednesday, March 19, 2014 4:35:42 PM EDT Subject: Wk3. A.Titievskaya

\section{Bureaucracy}

According to Merriam-Webster Vocabular bureaucracy is:

1. a. Administration of a government chiefly through bureaus or departments staffed with nonelected officials.

b. The departments and their officials as a group: promised to reorganize the federal bureaucracy.

2. a. Management or administration marked by hierarchical authority among numerous offices and by fixed procedures: The new department head did not know much about bureaucracy.

b. The administrative structure of a large or complex organization: a midlevel manager in a corporate bureaucracy.

3. An administrative system in which the need or inclination to follow rigid or complex procedures impedes effective action: innovative ideas that get bogged down in red tape and bureaucracy.

"Bureaucrats put government policy into practice, and therefore the federal bureaucracy has a large impact on policymaking. In order to get their policies passed, the president and Congress must work with the bureaucracy.” Controlling the bureaucracy can be a difficult task. Because the president cannot monitor everyone that is why much of what bureaucrats do goes uncontrolled.

What gives the bureaucrats the power-"the people who administer policy often know much more about those issues than the president or members of Congress.”

When Congress creates a new law or new program, it does not cover all the details on how the law will be implemented. "Instead, "Congress passes enabling legislation, which grants power to an agency to work out the specifics.” Of course the agency must stay within the stated bounds, at the same time "it has a great deal of latitude in determining how to carry out the wishes of Congress."

"The federal bureaucracy makes policies that affect how programs operate, and these rules must be obeyed, just as if they were laws. The rule-making process for government agencies occurs in stages. After Congress passes new regulatory laws, the agency charged with implementing the law proposes a series of rules, which are published in the Federal Register." 
I personally think that the bureaucracy plays a big role in federal policymaking through iron triangles and issue networks.

"An iron triangle is an alliance of people from three groups: a congressional subcommittee that deals with an issue, the executive agency that enforces laws on that issue, and private interest groups. Often, the members of the triangle know each other well, and people frequently move from one corner of the triangle to another. The members of the iron triangle work together to create policy that serves their interests.”

As an example of an iron triangle can be the following: "The Defense Department may want a new weapons system, members of congressional Armed Services Committees may want to look tough on defense by voting for a new system, and military suppliers want to make money by selling weapons systems. Therefore, it is in the interests of all three parties to push Congress to authorize the new weapons system.”

\section{References}

http://www.sparknotes.com/us-government-and-politics/american-government/thebureaucracy/section4.rhtml

http://www.merriam-webster.com/dictionary/bureaucracy

Author: Kiyoung Kim Date: Saturday, March 22, 2014 4:18:33 AM EDT Subject: RE: Wk3. A.Titievskaya

Hello. Alina,

Thank you for the excellent post. The bureaucracy would be widely used to denote something in a distinct flavor or aura, but must be a certain behemoth in any strong terms of reality which imposes in diverse ways. In one aspect, we generally connote or sense positively about our affluence or wealth from that word. In other aspect, we would likely conceive something negative, such as inefficiency, inertia as a little more extremely, corruption or procrastination, authoritativeness, and the like. The bureaucracy seems to plainly prove the evolution, professionalization, technological advances, economic and fiscal growth as well as the increase of social injustice or umpire role of the modern democratic government. On the other hand, it would not be a pun, while its reality to influence the government and society would come as undeniably strong. The bureaucrats perhaps would be a socially main class to represent the ethos, culture, intelligence, and economic status of nation or society. They would generally be true of the important role in the public policy making as you said of iron triangle. Then we can see two aspects of modern bureaucrats, who both produce and consume. How do you see any most effective way to ensure their accountability to the people? The tradition or practice of iron triangle would be ideal in terms of democratic accountability? How do you consider the status of bureaucrats as a consumer or citizen in these present days? Do you think if they are well afforded or satisfied with the job stability? Respectfully.

Author: Alina Titievskaya Date: Saturday, March 22, 2014 10:06:09 AM EDT Subject: RE: Wk3. A.Titievskaya 
Kiyoung, thank you for your questions!

- "Bureaucracies have traditionally been organized on the basis of purpose or function: hence their division into departments, ministries and agencies. The degree of centralization or decentralization within them varies considerably. Modern trends, however, are towards the divorce of policy-making from policy implementation, and the incorporation of private-sector management techniques, if not outright privatization.

- There is concern about bureaucratic power because of the threat it poses to democratic accountability. The principal sources of bureaucratic power include the ability of civil servants to control the flow of information and, thus, determine what their political masters know, the logistical advantages that they enjoy as permanent and full-time public officials, and their status as experts and custodians of the national interest.

- Control is exerted over bureaucracies in a number of ways. Mechanisms of public accountability to ministers, assemblies, the courts or ombudsmen can be established. The civil service can be politicized so that it shares the ideological enthusiasms of the government of the day. Counter-bureaucracies can be constructed to provide an alternative source of advice and to strengthen the hands of elected politicians."

Reference

http://www.palgrave.com/foundations/heywood/students/chapter/ch16.html

Author: Tiffany Austin Date: Thursday, March 20, 2014 3:30:28 PM EDT Subject: RE: Discussion - Week 3

\section{Main Discussion Post:}

Bureaucracy is a way of organizational functioning that is driven by forces other than competition. Ways in which bureaucracy impacts the rule making process and the role of agency heads within an organization are through division of labor, specialization, strict rules and subordination and exclusion of personal elements from the conduct of work (Gajduschek, 2003, pg. 702).

An example of the affects of bureaucracy on an organization would be the Georgia Department of Driver Services (DDS). This is a public agency in the state of Georgia that ensures citizens have proper documentation to safely operate vehicles on the state's roads and interstates. This organization is also responsible for issuing ID's and driver's licenses. The organization sets requirements for citizens to get ID's and licenses under the guidance of the state law.

\section{References:}

Gajduschek, G. (2003). Bureaucracy: is it efficient? Is it not? Is that the question? Uncertainty reduction: An ignored element of bureaucratic rationality. Administration \& Society, 34(6), 700-723. 
Georgia Department of Driver Services. (n. d.). Rules and regulations. Retrieved from http://www.dds.ga.gov/rules/index.aspx on March 20, 2014.

Author: Kiyoung Kim Date: Saturday, March 22, 2014 4:51:33 AM EDT Subject: RE: Discussion - Week 3

Hi. Tiffany,

I agree on your statement that bureaucracy is a way of organizational functioning that is driven by forces other than competition. That would be entirely perfect on the classic notion. Nonetheless, like the definition given by Alina, the increasing profile of exchange or mutual learning between the corporate bureaucracy and that of government could be some reality. As Kerwin and Shari illustrated, the bureaucrats may be viewed not solely as an enforcement officer, but would be amenable to a latitude of personal or social attributes. The climbers or zealots, for example, could entail much potential to distract the right way of forcing the public goals. The climbers would rather like to practice a competition who desire to outrival their competitors. The organizational purview of studies may divulge a convergence beyond the traditional distinction of market and non-market attributes. How do you consider if your statement stretches to the two concepts of rationality and efficiency? If the bureaucracy is irrational or against our nature and reason, could it be sustained? How much the social concept of private enterprises would eclipse the pure dimension of competitiveness? Respectfully.

Author: Keila Lacy Date: Friday, March 21, 2014 11:58:21 PM EDT Subject: Main Post: Keila Lacy

A bureaucracy is a method of administratively organizing large numbers of people who work in collaborative efforts. Organizations in the public and private sector, including universities and governments, rely on bureaucracies to function (Gajduschek, 2003). Government bureaucracy performs a variety of tasks to monitor activities and roles in hierarchy (Gajduschek, 2003).

The purpose of a bureaucrat is to assist in implementing government policy; to take decisions/ laws made by elected officials and put them into practice (MacDonald \& Franko, 2007). Some bureaucrats implement policy by writing rules and regulations, whereas others administer policies directly to people (such as distributing loans to small businesses or treating patients in a hospital setting). Various scholars have created models to explain the function of bureaucracies; to illustrate their purpose and effectiveness:

\section{Weberian model}

According to Max Weber, a bureaucracy illustrates the following characteristics (Kerwin \& Furlong, 2011):

Hierarchy: A bureaucracy is set up with precise chains of command so that everyone has a "say- so" in decisions on various levels. At the height of the organization, is a chief who oversees the total bureaucracy and powers flow in a downward motion 
Specialization: Bureaucrats specialize in a specific area of the issue under their agency. This allows productivity and effectiveness because the specialist does their duties, then passes the material along to another expert in that area.

$\square$ Division of Labor: Each task is divided into smaller tasks, and various people work on different parts of the task.

Standard operating procedure (SOP): Also called formalized rules, SOP instructs workers on how to effectively handle tasks and situations. Everybody follows the same guidelines to enhance predictability and proficiency so the organization can produce similar results in related circumstances. As new procedures are established under SOP and developed as circumstances change, bureaucracy can move at a limited pace.

\section{Acquisitive Model}

The acquisitive model can be noted by the following characteristics (MacDonald \& Franko, 2007):

Expansion: Leaders of bureaucracies constantly seek to enlarge the size and budget of their agency.

$\square$ Turf wars: Bureaucrats defend their responsibilities, resources, and jurisdiction from potential competitors. Even though government bureaucracies do not work for profit, agency heads still compete for power and prestige.

\section{Monopolistic Model}

Proponents of the monopolistic model believe that bureaucracies can be distinguished by two characteristics(MacDonald \& Franko, 2007):

$\square$ Monopoly: Federal bureaucracies face little competition and therefore act in a monopolizing manner.

$\square$ Inefficiency: Bureaucracies use their resources inadequately because they do not have to compete.

References:

Gajduschek, G. (2003). Bureaucracy: Is it efficient? Is it not? is that the question? Uncertainty reduction. An ignored element of bureaucratic rationality. Administration \& Society, 34(6), 700-723

Kerwin, C. M. \& Furlong, S.R., (2011). Rulemaking: How government agencies write law and make policy (4th ed.). Washington, DC: CQ Press.

MacDonald, J.A., \& Franko, W.W., Jr. (2007). Bureaucratic capacity and bureaucratic discretion. Does Congress tie policy authority to performance? American Politics and Research, 35(6), 790-807 
Author: Kiyoung Kim Date: Saturday, March 22, 2014 5:21:24 AM EDT Subject: RE: Main Post: Keila Lacy

Hi. Keila,

Thank you for the informative post. The three views seem fairly insightful through "the static, expansive, and monopolistic.” In your statement, federal bureaucracies would be largely monopolistic. Then we perhaps need to consider if its status would be any virtuous. In that context, how much the Weberian elements could offer the standard of evaluation since it comes as outdated in early of last century? According to Gadjuduscheck, Weber's theme might be prone of rationality or uncertainty reduction other than efficiency. If the people were to wish for an efficient government or efficacy in the public administration rather than monopolistic arrogance, can such wish stand on the paradigm of federal institution. How do you consider the last occasion, so-called a sequestration involving the interbranch contention and disagreement and in terms of monopoly or inefficiency? If you only can find a solution from the political election or accountability, which political party is to be principally responsible for that anomaly? Respectfully.

Response to Kiyoung

Thank you for taking the time to respond to my post. I always enjoy reading the content of your discussion posts because they add so much insight/historical perspectives to the theories and regulations of law.

I believe that our government and Constitution was constructed to follow Weber's theme, but it has become very difficult to define efficiency in the action/motives of government officials.

To add additional clarification, I do understand that the Webarian Model was created for bureaucracy, but it's structure of hierarchy and chain of commend can be beneficial to illustrate the checks and balances/effective governmental structure

\section{From KJF}

Which branch of government serves the enforcement function? Is criminal punishment inherently a congressional power? 


\section{[Week 4]}

Author: Kiyoung Kim Date: Saturday, March 29, 2014 6:14:36 AM EDT Subject: RE: Discussion - Week 4

Hi. Dr. Fandl,

Thank you for the question. I suppose it depends on how we connote the enforcement function. The legislature and judiciary would have their internal codes or regulations to administer their institutional mandate or needs. For example, the Court administrators or pertinent boards and commissions could set forth the salary scale or ethics standard. That could be the case within the legislature. Any more meaningful understanding of this concept would occur when the function is involved with the external actors or constituents. The interest and rights or loss and damage thereof as vested within the people or citizen would be the point of focus when we deal with the rules of law ideals or responsible public administration. In a limited exception, the interbranch controversies about the scope of enforcement authority may be disputed in the court proceedings, as in some countries of civil law tradition. The Courts often withdraw their engagement with the internal codes or regulation since it would fall within the class of institutional autonomy and not be destined to the external actors or people. Then the enforcement function, in this narrow and normal sense, would be carried by the executive and judiciary. The Lockean concept of separation of powers principle would be sheer to endorse this perception that he did not recognize the judicial power as independent from the executive function. That could be seen otherwise in Montesquieu, who perhaps found a more deliberate procedure, adversary context of function or process, and the nature of power centered to identify and recognize a law than to execute it. While the society evolves, the distinctive understanding of two branches would come in a more depth that the judicial review of legislation or administrative rules is considered as one inviolable essence of democratic rule. The rise and higher progress of administrative state would make it starker between the two passive and active branches.

The criminal policy and justice system would be a most antedated issue or policy area which drives us to think about, for example, the Hammurabi code in the Greek times. It would be a most sensitive issue that the feudal nobility and modern bourgeois exerted their every effort to safeguard from the arbitrary power of monarch or dictators. Some crucial elements historically proven a worst evil in the criminal justice system were inserted into the modern constitutionalism, for example, a cruel and unusual punishment in the Amendment IIXX, search and seizure, self-incrimination, right to confront the witnesses, jury trial and the like. Generally we may consider that the constitutional practice and principles of civilized criminal justice system would endorse the legislative power as a founded authority to define the elements of crimes and punishment. That could be inferred or implied from the rule of law ideals, separation of powers principle, parliamentary system of government, intrinsic argument of state government, due process of law concept and so. Assuming if the judges or agencies formulate the criminal law, then it critically encroaches upon the nature and reason of humanity that the enforcers are the same as legislators. A self-law is the one that the separation of powers principle would abhor. Respectfully.

From Kelia Lacy 
Hello Kiyoung

Thank you for a very detailed and informative discussion post! Your post was very precise in explaining the delegation of legislative powers and the authority of the Constitution in relation to administrative agencies. Great post!

Author: Divine Ayivor Date: Tuesday, March 25, 2014 10:59:30 PM EDT Subject: RE: Discussion - Week 4

How Delegation Doctrine impacts the authority of Administrative agencies to execute statutes.

For an agency to be able to fulfill its constitutional mandate, it must have delegated authority of a broad nature, enough appropriation for staffing, flexibility, and specific directions to make rules commensurate with its expertise to fulfill the requirement of the law enacted by Congress or by executive order. Congress, according to Article 1 of the Constitution, may not delegate its legislative powers. The courts struggle with this principle of delegation with play of words like "intelligible principle", "necessity", and "factual details", but it all gives administrative agencies the delegated powers needed to make rules to implement laws enacted by Congress or by executive order. As if the courts are circumventing the constitution with good intentions to protect the public interest. The rules are however subject to judicial reviews for accountability. Congress therefore, may authorize administrative agencies to make rules specific for implementation of laws in particular spheres, like the FCC or EPA, with limitations on how far the agency can go. The direction from Congress or the President given to administrative agencies must be specific with defined limits about creation of statutes. Congress sometimes acting under political pressure from the public gives vague statutes to administrative agencies to use their expertise in crafting solutions to problems Congress is not able to solve with legislation directly. After the agencies make rules, then Congress uses the powers of the Congressional Review Act (Sec 801), to reshape the statute or use Legislative veto to nullify the rules. Administrative agencies sometimes are under staffed or given appropriations less that what is needed for the task they are obligated to perform. An example was the creation of the Consumer Product safety commission in 1972. The commission was underfunded and understaffed. Congress gave it no flexibility and direction. The commission faded away until 2008 when it was reinstituted also with a high degree of vagueness.

Congress and the President must give administrative agencies the opportunity to come up with their own budget, give them specific direction and flexibility, when given assignments than to subjected administrative agencies to inadequate appropriations but yet expected them to perform effectively under duress.

Reference:

Harrington, C.B., \& Carter, L.H. (2009). Administrative law and Politics: Cases and Comments. (4th ed.). Washington D.C.:CQPress

Author: Kiyoung Kim Date: Saturday, March 29, 2014 4:28:59 AM EDT Subject: RE: Discussion - Week 4 


\section{Hi. Divine,}

Thank you for the informative post. I consider you properly epitomized three terms viewed as important to address the challenge to the non-delegation doctrine, i.e., "intelligible principle, necessity and factual details." If the legislative power is genetic, formulating, or creative, the administrative agencies should remain bound within the executory power. The intelligible principle could serve curbing such fashion of authority, since the direction and limits could be intelligibly circumscribed. The Congress could rely on the "necessary and proper clause" to base his delegation authority, which nonetheless should not contradict the structure and terms of Constitution. I mean that, even if the delegation comes in necessity, it still does not entirely fade away that the legislative power is vested within the Congress and that the executive power is conferred on the executive branch. Despite this, the necessity argument can support a justificatory logic for the legislative delegation as well. The factual details argument also reinforces the practice of delegation that the law-making function would not be dispensed away in good faith with the constitutional structure. In the court proceeding, the foreign laws, in some sphere, such as evidentiary phase, would be dealt as a fact other than law. Therefore, the Court could shift the burden to find and present the precise nature of foreign laws as the duty of parties or their counsel, not the one of court's. This hypothesis or viewpoint could be attributed more easily, I suppose, to our issue. In other words, the divisive line between the fact and law is not clear, rather easily blurred to find more possibilities of legitimacy on delegation. I was interested in the Congressional Review Act, but the legislative veto was once questioned in the Court since it impermissibly deals with the administrative decision in violation of the presentation clause to the review of President. Can you tell how the status of Act was gone if any? Another question is if the "budget on its own" (you mean the delegated agencies) could be possible if the fiscal authority would fall within the Congress and as partly involved with the President? Respectfully.

Author: Divine Ayivor Date: Sunday, March 30, 2014 5:42:28 PM EDT Subject: RE: Response to Mr. Kim

Always impressed by your post. Thanks for reading my post. As you rigthly pointed out "the divisive line between the fact and law is not clear, rather easily blurred to find more possibilities of legitimacy on delegation". So the courts on a case by case basis and sometimes based on precedents, walk the fine line of legal creativity and maneuvering as the deal with the limitations placed by the Constitution. The status of the act of Congressional Review is not gone. The Constitutional Review Act is a balance of power feature that allows the judiciary to validate the actions of the Legislative and Executive. A check and balance feature, with which courts can annul a statute based on its constitutionality. Appropriation is made by Congress, as the committees see fit and taking into consideration our national dept and what is available in the treasury. It will be fair to allow the departments so submit a feasible budget to the committees as the deliberate, but what the outcome will be is unknown. TSA hired lots of people but even I was able to get through a check point with a pocket knife, full large toothpaste tube and a bottle of water. All those things were to be confiscated not to be allowed on the airplane, but I took them on board. The point is failure in the bureaucracy to be blamed on the inefficiency of employees or on lack of appropriation? The answers is as elusive as the disappearance of Flight 370. No one knows. Thanks. 
Author: Gerry Curran Date: Wednesday, March 26, 2014 10:22:54 AM EDT Subject: RE: Discussion - Week 4

\section{Week Four Post;}

The Delegation Doctrine emanates from Article 1 of the US constitution which circumvents any desire Congress may have to delegate away any or its legislative powers. Yet it does not impose upon Congress a total ban on delegation in this regard as the same article later on gives it the tools and utilitarian means to perform the same legislative functions in other manners and ways.

It has largely been left up to the courts in the US to interpret what this doctrine means in practice. The courts journey in this regard started out with findings that the executive can implement policy through activating legislation via recognition factual detail and issuing orders based on this and using the law and policy as originally decided by Congress. It later went on to say that as law and rule making can at times be indistinguishable, and not at all clear, that limits or caps may be placed on delegated powers, that intelligible principles have to be set by Congress for each Act and law, delegation is allowable as a necessity of time and a deference to the expertise of agencies and executive officials.

In applying these principles, the Supreme Court has struck down Acts for not having specific procedures for the making of codes inherent in the Act - as total delegation is not allowed. It would sen here that Congress and the President would need to give direction as to the use of powers by the agencies they create or control - as the court has said there needs to be a level of accountability in the law as to the sufficient laying out of the scope of he powers delegated and whether the actor on behalf of the executive operated within same.

The text on administrative law uses the essay by Jaffes (1973) to tell us that a defense of real expertise residing in an administrative agency, is not enough for allowing for largely unfettered delegation of powers. Yet the Supreme Court - in Minstretta (1989) regarding sentencing policy and in regards to another matter of the EPA interpreting g the Clean Air Act - steered clear of offering an alternative wisdom to that of Congress regarding the levels of how much, and to whom, powers of policy judgment can be delegated. Yet the court has red circled the A.G.'s attempts to declare illegal practices already allowed by state legislation

So who under Law may make decisions ?

So Congress can devolve powers outwards to agencies, and yet cannot act alone as regards circumscribing agency actions, as the courts have a major input, and Presidents act on their own perceived or real power. The relationship is difficult and complex - with many areas of overlapping. Yet agencies have been described by judges as the deface fourth arm of government. Congress has been allowed by the courts to not so much veto legislatively the decisions of agencies but to have monitoring powers such as requiring all new rules to be put before the $C \& G$ with statements as to it general applicability and importance and its effective commencement date, and the $C \& G$ then reporting same to each house of the Congress which jointly must resolve to invalidate it.

Yet issues which do arise are not usually in an overextending of the arm of those 
delegated power - but by a clack of clarity in the originating legislation. For example in describing the public interest in laws the courts have decided that the said laws do not give agencies to act as a licensed promoter of general public welfare but to use the regulatory legislation as designed. It seems the direction of who makes laws and where they are best enacted has fallen to the courts to decide and that they instruct administrators to behave in certain fashion in this regard.

Other factors impacting on Agencies using powers and implementing laws

Dr James O'Reilly (2009) tells us of a pertinent example in the US - regarding toy safety. The Consumer Product Safety Commission (CPSC), had withered away between 1972 and 1978 due to neglect and lack of Congress provision for it. In 1978 new laws were introduced as a result of public concern over the safety of toys with lead in them and new legislation's passed for the commission to fill-in the gaps of, or fill out via regulation. He makes the point well that agencies get support based on levels of lobbying, sectorial pressure or concern and public disquiet and ability to public issues. In the instance he cites 2.2 million toys were recalled and this resulted in rushed legislation and a lack of staff to use the new powers to a decent level of efficacy. The role of an agency here can see them make use of multiple tools which can lead them to take a specific action against a significant violator of laws, or to draft specific rules to implement the law

\section{References;}

Harrington, C. B., \& Carter, L. H. (2009). Administrative law and politics: Cases and comments (4th ed.). Washington, DC: CQ Press.

Reilly,James. (2009)Video: Fundamentals of law and public policy: Administrative agencies - Authority and enforcement. Baltimore: Laureate Education, Inc. (Executive Producer).

Author: Kiyoung Kim Date: Saturday, March 29, 2014 5:09:46 AM EDT Subject: RE: Discussion - Week 4

Hi. Gerry,

Thank you for the informative post. Your statement between "a licensed promoter of general public welfare" and "regulatory legislation" would help to unearth some hidden basis of court rulings in review of delegating acts. The word, promotion of general public welfare, has a place in the Preamble of US Constitution, which would often be deemed as the responsibilities of political or active branches, say, the legislature and executive. The regulatory legislation would rather be gone with the legislature and judiciary. The differences between the regulatory legislation and regulatory rule could be a central focus of contention and in view of the delegation of legislative power. The classic notion of regulatory or police power, in much extent, even fueled the many constitutional controversies beyond the normal coordinate three branches and involving the theme of liberal society as well as due limits of public intervention. In this context, I suppose the regulatory nature of acts would receive the more stringent deals in terms of judicial control while the promotional act of general public welfare would come in a leeway. How much do you agree on this assumption? Do you agree 
if the Preamble has a normative power to bind the Courts other than the Articles or Amendments? Respectfully.

Hi.

Honestly I do not know enough about the US constitution to comment on its preamble, amendments, articles and main body of text - in answering your query. But I agree with you that their is more leeway allowed by the courts in relation to the promotion of the general public good - over say - the specifics of regulation. Our trawl through the cases is very interesting and I am learning lots as we progress week to week.

n.

\section{Regards}

Hi Kim

Great Post. What do you think about Congress using Section 706 (2) (c) of the APA as an oversight mechanism? 


\section{[Week 5]}

Author: Gerry Curran Date: Thursday, April 3, 2014 2:54:22 AM EDT Subject: RE: Discussion - Week 5

\section{Main Discussion Week 5}

O’ Reilly (2009) - informs us that working together and cooperation is a prerequisite for Congress and agencies to successfully execute and implement law. In assessing how best this is done and maybe why agencies are important in making rules, he cites a prime example of this not working in government sponsored access to health - (which as a non US resident I find novel as a means of accessing health care and in the involvement of politicians in so detailed a way). He examines the Medicaid / Medicare system because, although it is a policy or instrument made by Congress and creating agency involvement - control over its extensiveness in effecting lives is largely kept by Congress itself.

This is not a good thing he argues - as the same legislators are susceptible to drug and service providers who are there lobbying and applying pressure . Congress is in effect micro manning medicaid. The expertise of agency is not at play. Constituency forces have a larger than normal input.

Congress expresses this over-interest and control through reducing or requiring appropriations to be used in a certain way; through the use of public congressional hearings, Congress interferes in terms of what conditions, areas of population and even diseases are covered by health budgets: This process can lead to Congress flying in the face of science at times as they write the cheques. Rather than allow agency objectivity in patient care, Both state and Congressional politicians put pressure on medicaid and medicare deliverers to answer various national, constituent and local needs and thus decisions best left to experts are politicised.

One of the most important roles for rule making and review of same is that public confidence in rule making might be said to be increased as it is subjected to review and oversight by by the legislature, president and the courts. Mechanisms of accountability are important in this regard - that they are designed so as not to slip into a dominance and dependence scenario. Yet 'unwelcome' oversight by non practitioners can be overcome by the machinations of bureaucrats, or the language use and familiarity of same by the experts in an agency, stymying politicians who although charged with oversight, are bereft of similar access to the minutiae of practice or language of a very specific field of rule making.

The Reagan and Bush presidencies were more likely to review agencies via the OMB than the Clinton administration. However an executive order signed by Clinton changed the process - whereby all new rules - deemed as significant by agencies had to be discussed in draft form with the OMB in advance and then it was up to the OMB to review or not. This in effect reduced the number of reviews dramatically - by around $75 \%$ between 1992 and 1997 - but it increased the president's influence as the numbers of rules approved without change also reduced from almost $65 \%$ in the last year of the Bush administration to under $38 \%$ by year five of the Clinton administration. 
OIRA also gives specific attention to rules on behalf of the process of Presidential review and in 2003 it was found to have influenced 25 out of 85 rules it examined. The number of rules altered or influenced as to content and scope by informal contact prior to submission or as a result of knowing that the review process is as proactive as it in the White House gives the President real input into the daily application and formulation of public policy, as it streams from primary legislation, to secondary orders, and tertiary rules and regulations.

The EPA has been the subject of much attention in this regard - but from the courts (Furlong \& Kerwin, 2012:262) tell us that - although the agency is frequently reviewed - not least in the courts where it is a regular victor in these battles - the very filing of an action can lead to the agency changing its approach and practices. Its attitudes to formaldehyde and landfill are cited as examples of this- and the presence of potential review focused the agency t interact and reach agreement with litigants. But on other occasions the courts can become active to the point of asking for progress reports on how the agency is conducting changes needed or ordered, applying timetables to same, and even over activism by a judge asking for an overview of all personnel and budgetary resins why a ruling might not be adhered to.

\section{References}

Furlong, S \& Kerwin, C. 2012. Rulemaking: How Government Agencies Write Law and Make Policy Chapter 6, "Oversight of Rulemaking”

O’Reilly. 2009. Video: Laureate Education, Inc. (Executive Producer). (2009). Fundamentals of law and public policy: Administrative agencies - Oversight and accountability. Baltimore: Author.

Author: Kiyoung Kim Date: Saturday, April 5, 2014 6:39:47 AM EDT Subject: RE: Discussion - Week 5

\section{Hi. Gerry,}

Thank you for the informative post. I was persuaded that it would not be a good thing the Medicaid/Medicare system would largely be kept by Congress itself. A scope of leniency needs to be delegated to the expertise of bureaus varying with the changing circumstances of specific policy environment. As per your status, for example, the Congress may be general to reduce a governmental spending. I guess if a more focused context from the bureaus could narrowly draw specificities in response with the emergencies or predicament of non US resident. You implied that the bias or flaws from an undesired contact with the interest group could possibly denigrate the goals of public health system. Actually the area would be a grey zone between the politics and criminal policy in South Korea. The Korean authority can be seen to practice an imposing criminal view so that a lobbying could be corruptive and punishable if it involves a pecuniary interest. The divisive line would be narrowly tailored and clear, as a matter of statutory law, to a defined scope of permissibility. The US also enacted the Anti-corruption Act, but I suppose the lobbying would generally be perceived within a highly permissible scope of political activities. That could guarantee an informed decision, and likely works as a policy network. You also raised the aspect that the judiciary could occasion to deeply involve about a general direction or reprimand. I may ask questions. How do you consider the merit of lobbying. And could the AA be operative to include the Congressman or lobbying? Do you think it necessary to ensure a sanctity of public office? Or 
do you like it to be left more generously since the Congressman may be immune to perform his political role? The Court, as a matter of law, could not give an advisory opinion, and has to be insulated from the disputed parties. It would work to increase a neutrality and impartiality as well as the intention of separationists. An advisory opinion or general nature of rule and power would remain with other branches. Your mention seems to contradict with this original feature of inter-branch dynamism. What is your thought about the desired form of intervention from the judiciary? Respectfully.

Author: Gerry Curran Date: Saturday, April 5, 2014 11:39:51 AM EDT Subject: response to Kiyoung

$\mathrm{Hi}$,

It would take me another week to research and discuss your questions fully!! But I do not like the influence of lobbyists or any corporate donation to politics - or any large donation from individuals. I think lobbying should be open, favour free, and registered as to who lobbies who, about what, and when. I think the courts should give advisory opinions as they are free from needing re election and are more impartial and objective. I am a great supporter of court's review of regulators and of anyone who can operate power over us. The balance in the US seems right and keeps everyone on their toes as to demarcation of powers and not over using their own.

Regards

Gerry

Author: Melissa Rosa Date: Thursday, April 3, 2014 1:29:45 AM EDT Subject: RE: Discussion - Week 5

Regulation is to maintain a level playing field. Laws and regulations can be identified that might be burdensome and unreasonable. Congress created the federal agencies to make sure that the laws were carried out properly. The President supervises the work through cabinet secretaries and department heads. The President can also propose that a new agency be created. It is important that the agencies are being overlooked because billions of dollars are being spent for federal grants, contracts, programs, environment pollution, and labor. The oversight is another way of guaranteeing that the money is being spent for the right purposes and not being overspent. Agencies are making rules to benefit and not destroy.

The rules also must be consistent with the President's priorities. Priorities are set when it comes to rulemaking for more emergent matters. Courts can vacate rules and remand them back to the agency meaning the agency will need to spend more time and money on rulemaking for the same issue.

Center for Effective Government. (2014). The players in rulemaking. Retrieved from http://www.foreffectivegov.org/node/3462

Author: Kiyoung Kim Date: Saturday, April 5, 2014 5:02:00 AM EDT Subject: RE: Discussion - Week 5 


\section{Hi. Melissa,}

Thank you for the good posting. I agree that the regulation is to maintain a level playing field. I may ask some questions, which also would be related with the international organizations. You may know that the argument "level playing field" or "free riders" had been intensively exchanged for the freer or fair trade regime in the world. In WTO, for example, the level playing field often means deregulation of unnecessary national burdens against the enterprises. How do you see the extent of domestic regulation to serve the enterprises? Excessive to be diminished? Or short to abandon many important social justice agenda? Typically, how do you assess the pros and cons of Obama Care? Respectfully.

Author: Kiyoung Kim Date: Saturday, April 5, 2014 5:17:39 AM EDT Subject: RE: Discussion - Week 5

\section{Hi. Melissa,}

Please disregard the first response which bears your main discussion post. In the process to post my response, it was mishandled and erroneously uploaded. I may ask one more question in view of comparative government. You stated that the rules also must be consistent with the President's priorities. In the presidential system of government, the administrative agencies might face with the conflict of authority between the congressional act and presidential control or priorities. Within the parliamentary system, one general election alters everything, but the basis of authority would split between the Congressional and Presidential election in the US. If the agencies earnestly believe the will of Congress would be clear, can he deny the presidential priorities? For example, the sequestration in the last year may be partly remedied by the initiative of Executive during its effect. Could he or she not respond with the initiative that the sequestration should be completely perfected on the will of Congress? Respectfully.

Author: Jessica Stanley Date: Friday, April 4, 2014 11:21:43 PM EDT Subject: RE: Main Question Post

The focus of oversight in the rulemaking process depends on the branch in question. Kerwin and Furlong (2011) states that Congress and the President attempt to promote their policy preferences especially when controlled by different political parties. The judiciary, on the other hand, ensures that functions are performed according to basic constitutional principles (Kerwin and Furlong, 2011). Each branch has their own role and motive in the rulemaking process however as a whole they are essential and vital in implementing public policy.

Oversight is important in the rulemaking process to ensure that administrative agencies are executing policies within their jurisdiction. The check and balance of the three branches of government allows for tight control over administrative agencies and provide accountability. Laureate Education (2009) addressed that Congress is controlling to rule makers as they delegate powers and provide extreme pressure to agencies for particular outcomes. This can hinder the scientific importance of a policy and one in which should be the focus. Oftentimes the focus is not scientific since Congress writes the rules and the checks to administrative agencies (Laureate Education, 2009). 
The example of CMS regulations based on Congressional provisions provided by Laureate Education (2009) is an excellent example. As a previous employer contracted by CMS, it was difficult for the agency to keep up with the constant revisions and expectations. The time constraints, increasing number of claims, and low staff due to not enough funding did not allow the doctors and nurses to fully devote their attention to the evidence provided in the claims. This created an increase in Medicare claims being appealed a third time seeking the guidance by an administrative law judge. As a result, the higher number of mistakes an agency makes due to congressional provisions, the more likely the agency will be subject to a congressional hearing, loss of contract, or replacement. In conclusion, oversight is important in the rulemaking process as a means of guiding administrative agencies through a policy change, allowing agencies to define how they will implement the policy, put pressure on agencies, and set the stage for accountability to be measured.

\section{References}

Kerwin, C. M., Furlong, S. R. (2011). Rulemaking: How government agencies write law and make policy (4th ed.). Washington, DC: CQ Press.

Laureate Education, Inc. (Executive Producer). (2009). Fundamentals of law and public policy: Administrative agencies - Oversight and accountability. Baltimore: Author.

Author: Kiyoung Kim Date: Saturday, April 5, 2014 8:19:50 AM EDT Subject: RE: Main Question Post

\section{Hi. Jessica,}

Thank you for the excellent post. I agree that "oversight is important...through a policy change, allowing agencies to define how they implement the policy, put pressures on agencies..." Your statement, nonetheless, may be little reflexive on the bureau dominance view while the accountability to the principal or role of interest representation would be emphasized. A latter view may pertain to the principal agent theory. The possible weakness of this view would lie in that the independence or flexibility of agencies could be neglected. You also stated, "Congress and the President attempt to promote their policy preferences especially when controlled by different political parties.” This implies that the shift of administration on political election or slim majority of Congress would impact to reorient the previous policy posture or basic objective. Still we see some needs to build a continued attitude of bureaucracy since it would be the sort of independent fourth branch and the bureaus often come permanent or are autonomous from the political influence. How can you reconcile a conflict within the strong need of oversight and independence of agencies? Respectfully. 


\section{[Week 6]}

Author: Michelle Early Date: Wednesday, April 9, 2014 3:13:17 PM EDT Subject: Michelle Discussion 1 - Week 6

\section{Hello Class,}

As with any transition, some things fall in between the cracks. This can occur in many areas of life including the transition of staff (or presidents) from old to new. During the transition of President Jimmy Carter to his successor, the term "Midnight Regulation" was created in an attempt to describe the fact that many regulations that get pushed in the final days of a president's term. Carter set a record for the number of pages printed in the Federal Registry during the midnight period (election day to Inauguration Day) of 24,531 (www.mercatus.org). However, in Bill Clinton's 2000 transition, he surpassed this number to set a record of 26,542. In his final Days, Clinton was able to get a record number of promulgated regulations. One of the most controversial regulations passed during Clinton's final days dealt with "a reduction in acceptable arsenic levels from 50 to 10 parts per billion

(www.people.howstuffworks.com)." This was a major sore spot for succeeding President George Bush because of the decrease had a potential significant financial impact on many industries. He later had this stopped through an executive order. This simple act of reversal on Bush's part made many believe that he was not a proponent of the environment but that his desires lied elsewhere. After some time, Bush reversed his decision and accepted the regulation originally set by Clinton.

Although not a direct result of Clinton's regulation, there exists an agency that is dedicated to the environment and the protection of materials that affect the environment and its population. This agency is known as the United States Environmental Protection Agency (EPA). According to the EPA website, many laws and regulations exist to protect the environment through this agency. More information on Clinton's impact Arsenic regulation in water can be found on the link below.

References

http://mercatus.org/sites/default/files/publication/Midnight_Regulations.pdf

http://people.howstuffworks.com/midnight-regulation.htm

http://water.epa.gov/drink/index.cfm

http://nepis.epa.gov/Adobe/PDF/P100EC9W.pdf

Author: Kiyoung Kim Date: Friday, April 11, 2014 2:13:37 AM EDT Subject: RE: Michelle Discussion 1 - Week 6

Hi. Michelle,

Thank you for the informative post. Actually the higher environmental quality accordingly may require a higher cost that the enterprises have to bear. The common people would not 
like to suffer from a degradation of environment to the interest of capitals and enterprises. The climate change arguably would be factored by the abusive exploitation and for the profit of industries. The recent ideas of green policy and institution would make a little cure in terms of this social injustice. The tax policy in stalemate of the traditional concept of corporate taxes would be critiqued. A title of taxes may be explored to enrich the accountability of pollutive or anti-environmental practice of capitals. The national economy and growth rate, on the other hand, depend on the enterprises and producers than consumers or commons. The unemployment rate also cannot be improved if they would foresee unfavorably. The international pressure to standardization in this realm of public policy might be sore to denounce the US position of the Tokyo protocol in this decade. I agree that an imprudence and caprice must certainly exist over the transitions of Presidency. How do you see any major reason that the new administration has to deny at first, and take an aftermath to rethink the midnight regulations? Respectfully.

Author: Tiffany Austin Date: Wednesday, April 9, 2014 2:02:43 PM EDT Subject: RE: Discussion 1 - Week 6

\section{Main Discussion Post:}

The policy area I chose for this discussion is veteran health care. Veteran health care is run by the Veteran's Health Administration which is the largest integrated health care system in the country. There are over 1,700 site where veterans can receive care and 8.76 million veterans are served at these sites each year (Veterans Health Administration). The Veterans Health Administration is an administrative office within the Department of Veteran Affairs (Department of Veteran Affairs).

Midnight regulation is the spike of new regulations that are proposed at the end of a President's term. During this time, the regulations are reviewed by the Office of Information and Regulatory Affairs (OIRA) where they focus on regulations that may have an annual effect on the economy of \$100 million or more (Birto and Rugy, 2009).

A regulation that was proposed during midnight regulations that can effect veterans health care was the Veteran's Administration's proposal to change informed consent regulations for HIV testing. This regulation would effect the Veterans Health Administration since it falls under the Veterans Administration in health care. The purpose of the regulation is to amend Department of Veteran Affairs Informed Consent regulations to update requirements concerning HIV testing in order to be consistent with the Veterans Mental Health and Other Care Improvement Act of 2008 (Sapien and Nankin, 2008).

\section{References:}

Sapien, J. \& Nankin, J. (2008). Midnight regulations. Retrieved from http://www.propublica.org/special/midnight-regulations on April 8, 2014.

Birto, J. \& Rugy, V. D. (2009). Midnight regulations and regulatory review. American Bar Association Administrative Law Review (Winter, 2009). 
United States Department of Veterans Affairs. (n. d.). Health Care: Providing health care for veterans. Retrieved from www.va.gov/health on April 8, 2014.

Department of Veterans Affairs. (n. d.). Department of veterans affairs. Retrieved from http://www.va.gov/ofcadmin/docs/vaorgchart.pdf on April 8, 2014.

Author: Kiyoung Kim Date: Friday, April 11, 2014 2:31:20 AM EDT Subject: RE: Discussion 1 - Week 6

\section{Hi. Tiffany,}

Thank you for the helpful posting. You implied that the midnight regulations might be one way to produce a maximum of rulemaking effect by dumping a large number of undecided or indefinite, but possibly important policies to serve the public good. The transitions of government may allow the bureaus to act likely the students in the last cram for examinations. Often the switch of government would be one major attribute in the liberal democracies while the past paradigm of communists would endure in reign, perhaps idealistically permanent for the working class. The assessment of transitions between two presidencies in this context raises an interesting comparison about the pros and cons of midnight regulation. How do you think it most effectively achievable if to reduce the cons and increase the pros within this tradition and practice? Respectfully.

Author: Belinda Szerletich Date: Wednesday, April 9, 2014 9:48:57 PM EDT Subject: RE: Discussion 1 - Week 6

Stem Cell Research Enhancement Act is a policy that I selected for this week's discussion assignment. The Stem Cell Research Enhancement Act defined as an institutional review committee that reviews specific requirements regarding cloning, gastrulating, embryonic and nuclear transfer of genetic material of a human being that constitutes stem cell.

President George Bush addressed stem cell research nationally on August 9, 2001. Karch (2012) noted that during Bush's televised announcement that the federal government would place certain limitations on funding such research policies. Shortly, after Bush's announcement regarding stem cell research programs debates began to surface. Several Republican Party Representatives were divided and began to argue over supporting such a policy because of the conflict involvement of abortion laws.

One specific agency that would be affected over such an Act was the Department of Public Health. The Commissioner of Public Health raised specific issues with the policy and the involvement of such research. The Act established provisions to target establishing subsequent fine to any violators. The Act would allow Agencies the right to enact fine amounts of not more than fifty thousand dollars or jail time not exceeding more than five years. Another particular problem the Department of Public Health encountered was verifying that human donations involving embryos, human eggs or sperms are donated voluntarily,

In 2006, President Bush vetoed portions of the Stem Cell Research Enhancement Act (Karch, 2012). Over the years, Presidents amend or veto previous Acts that help create new 
legislation for the State. For example, legislative lawmakers were aware of such high level interest stem cell research contributed to abortion laws. It also raised a red flag in the Wade $v$. Roe case regarding abortion. Like any research, bipartisan support becomes an issue involving restrictions for embryonic stem cell research funded by paid taxpayer's verses federal government.

\section{Reference}

Karch, A. (2012). Vertical Diffusion and the Policy-Making Process: The Politics of Embryonic Stem Cell Research. Political Research Quarterly, 65(1), 48-61. doi:10.1177/1065912910385252

Author: Kiyoung Kim Date: Friday, April 11, 2014 3:01:43 AM EDT Subject: RE: Discussion 1 - Week 6

\section{Hi. Belinda,}

Thank you for the good posting. The stem cell research is one of globally renowned issues which frontiers at the cutting edge of scientific field along with the Big Bang or space discoveries issue. I am not well versed with that issue, but in my knowledge, it entails a layer of issues from the need of scientific advancement, to the national or human standard of decency through the interests of industries. A similar issue perhaps would be an ethics in the animal-related research and corresponding regulations. We. Korean public, once experienced a nation-wide and ferment support for the world renowned researcher, W.S. Hwang, by donating the human eggs or sperms voluntarily. This turned into a disappointment on the occasion of his alleged violation of research ethics. He. Nonetheless, still makes a contribution with the patents and additional success. Since the area of research is far upfront and can possibly make a great deal of industrial benefits, I suppose it would not discontinue. How do you follow up with the status of regulation on this issue in the US? I like to ask another question about your statement. You said that the President Bush amended or vetoed portions of Act. As far as I know, a line item veto is permissible in the practice of US constitutionalism, but I am not sure if the Executive branch would be competent to propose the amended or added provisions of Congressional acts. Granted that such authority was declared clearly in the Korean Constitution, we could do that. Can the President of US submit a revised proposal in addition or amendment to the approval of Congress? Respectfully.

Author: Belinda Szerletich Date: Friday, April 11, 2014 9:24:35 PM EDT Subject: RE: Discussion 1 - Week 6

\section{Response to Kiyoung Kim}

Well President Bush addressed the topic of stem cell research in his national televised address in August 2001, by 2006 President Bush veto the bill due to much publicity involving fertility clinics. I believe that President Bush was pushing the issue through legislation. Stem cell research has been a hot topic from 1999 to 2008 and over 471 bills had been passed through legislation for policy approval. Through my research I have not found anything that says there is limitation placed on president's amendment rights. I would need to go back a little 
further to see if this issue was raised during a presidential election year. That may make a difference when amending certain Acts.

Author: Shari Tewa Date: Wednesday, April 9, 2014 10:15:02 PM EDT Subject: Shari Tewa Main Question Post

In searching through this week's reading to find ways in which agency heads might influence rulemaking we have the glaring example of the Food and Drug Administration (FDA) that in 2005 did not want to cooperate with the inquiry into their refusal to approve the morning after pill on the market, citing their concerns that the pill would encourage promiscuity in underage girls. (gao.gov) Although there seems to be some conflicting reports circulating as to how the decision was reached, one thing was plainly stated: it was politically motivated according to the critics of the decisions based on the draft report (Newman, 2005). What is interesting to note is that was the only drug that was not approved from what is called prescription to OTC switch in 10 years, (1994-2004). Because of unusual procedural activity associated with the creation of this rule, which included the fact that a decision may have been made prematurely, the GAO intervened. Advisory committees had approved the rule and it is unclear what was the motive behind the then deputy FDA Commissioner Lester Crawford's decision, although the NY Times reports that "religious conservatives" (Newman, 2005) brought pressure to bear on the issue. It is clear that the doors of the "bureau dominance” school are wide open here. Kerwin, Furlong (2011, p. 278) inform us that if "politics play a role in policymaking; it is largely to the extent that the bureaucrats allow". Here we can say that the "advocate" bureaucrat, one who "promote their own views" is the category that Mr. Crawford may be placed in since "several legislators and scientists ...complained that the FDA was putting politics ahead of science.” (Newman, 2005).

Another way in which agency heads influence the rulemaking process is through their faithfulness of the President's or their own agenda. In the Obama administration pick of Cass Sunstein to head OIRA (Chemnick, 2012) a heavy dose of cost-benefit analysis seems to be the choice in promulgation of rules, as evidenced by the recent decision of Barack Obama to not lower the standards for "smog-forming emissions from power plants and new toxic emissions standards from industrial boilers" based on a conclusion that "the cost to implement would outweigh the cost in benefit to the general public (Chemnick, 2012). Sunstein's policies have solidified at OIRA given his "history of hostility to these rules." (Chemnick, 2012) One wonders is Sunstein is "faithfully following the President or pursuing his own agenda". (Kerwin, Furlong, 2011, p. 277) One would assume the latter to be true in this case since according to Chemnick, (2012) "his views were well established before coming to the White House.”.

I believe that none of the agency types described, "the zealot, climber, conservers, statesperson, advocates” (Kerwin, Furlong, 2011, p 274) should allow their personalities to dominate the rulemaking process. The finalization of rules should not reflect the personal or political desires of the head of the agency; the agency head is the representative of the public in the process, not of the official that appointed him/her or the lobbyists throwing their money at the issues. The prevailing interests of the people should govern the decision making at all times, which is the characteristic of a true democracy. As noted on page 279 of Kerwin and Furlong's book (2011) "when these motivations and behaviors manifest themselves in rulemaking agencies, the results of rulemaking are affected.” 


\section{References:}

Chemnick, J., 2012. Regulations: Rulemaking 'bottleneck' is agency that enviros love to hate. E\&E Publishing. LLC Retrieved from: http://www.eenews.net

Food And Drug Administration. (2005) Decision Process to Deny Initial Application For Over-The Counter Of The Emergency Contraceptive Drug Plan B Was Unusual. Retrieved from: http://www.gao.gov

Newman, M, 2005. FDA’s Rejection of Contraceptive Is Questioned. NY Times. Retrieved from: http://www.nytimes.com

Author: Kiyoung Kim Date: Saturday, April 12, 2014 6:10:51 AM EDT Subject: RE: Shari Tewa Main Question Post

Hi. Shari,

Thank you for the excellent post. You raised two perspectives, say, the bureau dominance and faithfulness to the President, on the basis of which the rulemaking would generally be structured, oriented, and pursued. The issues or attribute of agencies seemingly could influence the pattern of practices within the agencies. A science, health or religious issue could maintain a relatively higher level of insularity from the politics as we see in the case of FDA, but the general or economic context of administration, such as ORIA, tends to be controlled sensitively to serve the political will of President. How can you draw a proper extent of agency role between two strands, i.e., advocacy of public servants and their loyalty to the line authority? You stated the motivations and behaviors as a representative of public should be valued than the political desires or personal wishes of heads. One version also argues that the affirmative action to employ the minority officers, for example, in the bureau of Indian Affairs, would make the government more effective and productive since they know their issues more seriously either to serve their minority community or to address their issues. This concept also assumes some attribute of representation beyond a mere administration or machinery of agencies. Do you agree that such affirmative action has to be sustained? Respectfully.

Author: Shari Tewa Date: Saturday, April 12, 2014 4:23:24 PM EDT Subject: Shari Tewa response to Kiyoung Kim RE: Shari Tewa RE: Discussion - Week 2

Hi Kiyoung,

Thank you for the kind comments. I do believe in affirmative action but it must be very carefully measured so as not to upset the balance at the expense of the majority.

Shari

Author: Sheila Waters Date: Friday, April 11, 2014 1:54:19 AM EDT Subject: RE: Main Discussion Post 2 - Week 6 
Kaufman (2008) described bureaucracy as, “ a loose collection of many components comprised of myriad, diverse sets of public servants in different agencies and locations; with numerous functions and missions ... having a great variety of skills, specialties, and degrees of authority" (p. 259). By that definition it is easy to see how some agencies may exert tremendous influence while others very little. Agency heads are under tremendous political pressure and work against multiple constraints in the complex process of rulemaking (Kerwin and Furlong, 2011). They are often flummoxed at the end of their tenures because they might not have been as effective in creating change as they thought they would be. Agency heads use a variety of types of information to influence the rules being made to achieve the goals and objectives specified by their political leaders.

One of the ways agency heads influence rulemaking is by gaining a high level of autonomy and operating with a low level of oversight. A high level of autonomy would be based on the amount and level of critical technical, scientific, economic, administrative, and attitudinal information at their disposal. Having a low level of oversight means having a keen understanding of how programs function coupled with the inability of constitutional lawmakers to monitor and control agencies due to lack of resources, power, or incentives (Kaufman, 2008). Another way agency heads influence rulemaking is by exercising the ability to successfully manage the numerous orders, requests, and suggestions from all directions including elected officials, interest groups, various governmental committees, and the press without overly timid compliance, head-on confrontation, or coming under the persistent, sharp scrutiny of oversight activities that may result in negative appropriations that prevent impedes the agencies ability to perform its intended task of creating rules that implement the laws and statutes passed by the constitutional branches who delegate authority to agencies.

Agency heads should influence rulemaking by adhering to the intentions of the constitutional branches of government that delegated them the authority to interpret the law in the public interest. It appears that increased levels of authority translate to increased efficiency because any conflicts between the different governmental branches can be mitigated by the expertise inherent in the bureaus' myriad human resources. For example, the increase in the Executive Branch's "reorganization powers enabled them to make the administrative establishment more responsive to their wishes, their department heads gained legal authority over their bureaus, and, the president's executive office and White House staff can exert direct control over administrative action called "the administrative presidency" (Kaufman, 2008).

Kaufman, H. (2008). Ruminations on the study of American public bureaucracies. The American Review of Public Administration, 38(3), 256-263

Kerwin, C. M., Furlong, S.R. (2011). Rulemaking: How government agencies write law and make policy (4th ed.). Washington, DC: CQ Press.

Author: Kiyoung Kim Date: Saturday, April 12, 2014 5:33:56 AM EDT Subject: RE: Main Discussion Post 2 - Week 6

Hi. Sheila, 
An excellent post. Your suggestion seems persuasive that a high level of authority and low level of oversight would increase an effectiveness and efficacy for the administration or agencies. The idea would retain its power of persuasion through a level of bureaucracy including the top Executive officer. I generally agree on your view since a most productive leader or heads of organization would certainly be those who are talented to exploit the utmost potential or capabilities of followers. You implied that the role of Executive Branch or White House would determinatively upstage the agencies by using reorganization powers or in the context of administrative presidency. I would see that the leaders need to hold a consistency and predictability about their power of internal control. The reprimand or awards has to be merit-based and prepared in advance about the standards which the followers would foresee and be enthusiastic to comply with. A sudden reorganization or arbitrary administrative presidency may fail if without any specific standard or guideline. The administrative heads also need to prepare some internal ethics or regulations even if he defers with a high level of authority. The political appointees' last minute flummox might come at edge, but can conflict with the continued base of predictable administration or internal practice. How do you see if the extent or structure of Presidential or heads' primacy be defined in terms of external and internal constraints? For example, would the power to reorganize be such extended to the independent tribunals executing an adjudicatory power? If the executive orders or internal regulations are to be once rendered and continued over a bunch of years, could the President or heads would deny them without a process and for the reorganizational or disciplinary purpose since he or they are the authority to create those? In that case, can the aggrieved parties litigate its legality in the courtroom? Respectfully.

Author: Thomas Stone Date: Friday, April 11, 2014 11:18:46 PM EDT Subject: Thomas Stone WK6 Disc2 Initial Post

\section{Two Ways Agency Heads Might Influence Rulemaking}

According to Kerwin and Furlong, rulemaking affords a chance to inspire the direction and subject matter of American public policy. The rulemaking process may involve many persuasive and vigorous changes, along with the involvement of numerous individuals of different agencies, for laws to be passed. Rulemaking for individual agencies is affected in many ways by the agency heads own beliefs and their way of interpreting the rules as written. The agency heads are in many ways influential to the decision on laws on a greater outlook. Their many ideas of assessing the value of the law or rule for the agency, which would allow for complete resilience towards the administration or the public. The ability to predict the future of an agency is unrealistic; however, the agency heads will work hard at proving their ideas of laws would complete the rulemaking process for that agency.

\section{Agency Heads Degree of Influence on Rulemaking}

The amount of influence agency heads should have would vary depending on the size of the agency and the number of agency heads there are. An agency with five agency heads would not be making the right decision to have those individuals responsible for the structure and creation of rules, regulations or laws. Rulemaking for agency heads is important for the correct interpretation of the laws, rules or regulations and may be used for the purpose of accountability of the actions taken by the agency heads. Overall, I believe that agency heads should influence rulemaking for individual agencies. As leaders of specific agencies, their 
knowledge, and influence should help the agency make the correct decisions concerning the development of rules or laws.

References:

Harrington, C.B., \& Carter, L.H. (2009). Administrative law and Politics: Cases and Comments. (4th Ed.). Washington D.C.: CQ Press

Kerwin, C. M., Furlong, S.R., (2011). Rulemaking: How government agencies write law and make policy (4th Ed.). Washington, DC: CQ Press.

Author: Kiyoung Kim Date: Saturday, April 12, 2014 4:47:25 AM EDT Subject: RE: Thomas Stone WK6 Disc2 Initial Post

\section{Hi. Thomas,}

I agree that the rulemaking process may involve many persuasive and vigorous changes. The administrative pecking order also results in that numerous individuals of different agencies will involve. OMB and OIRA would be generally indispensable if the budget and finance of programs would be entangled through a rigorous review for sound management. You correctly implied that the ability to predict the future of an agency is unrealistic. You said that the size of agency and the number of agency heads would be an important factor to determine the amount of influence from agency heads. I may ask several questions about your statement. What do you consider the most of impediment to make the changes to dropped, delayed, halted or derided? Can you answer among the external and internal stakeholders? Do you say if the ability to predict the future of agency would not be unrealistic if without the kind of transitional chaos between two administrations? How do you agree if his personality or origin of heads authority would be more important that the size of agency and the number of agency heads? Thanks. Respectfully. 


\section{[Week 7]}

Author: Sheila Waters Date: Saturday, April 19, 2014 12:49:00 AM EDT Subject: RE: Main Discussion Post - Week 7

The example I used for the Application Assignment this week focused on the lawsuit brought against the Secretary of Labor by Sea World of Florida LLC. The corporation contested a determination by the Occupational Safety and Health Administration (OSHA) that the corporation was in of violation of Section 5(a)(1) of the OSHA Act when animal trainer Dawn Brancheau was killed by an orca whale during a public performance. She was one of several handlers killed or injured by one of the corporation's sea animals.

Author: Kiyoung Kim Date: Saturday, April 19, 2014 6:06:55 AM EDT Subject: RE: Main Discussion Post - Week 7

Hi. Shelia,

Thank you for the fine posting. I agree that the OSHA standard would be a popular subject for both employers and employees. Importantly, however, the standard could affect the ability or quality of workers in some cases which could lead to the misfortune of public. For example, a tiring work schedule may contribute to the airplane accident or sea tragedy of massive victims. Korea now mourns of nearly 300 deaths in the ferry, who are mostly high school students. The captain's disloyalty and faithless course of action in the emergency not rages the Korean public. It is in doubt, however, if he would suffer from the squeezing work demands. OSHA would be invented, then, to respond with the larger stakeholders beyond the capital and workers. The Court generally seems to tilt on two propensities where they would more likely save a traditional harm, often tort-framed, but become more reluctant for the general or scientific harm. The causation would stand significantly in this deal, which we can know is now symptomatic of smoking litigation over the nations. The court seems not to readily assume an underwriting role for the modern science and enhanced standard. The cost and benefit in the current standard of national economy and causation seemingly are an important point that the Court may deliberate. Given the attribute of accident, it may impose an emotional distress of spectators. How was the case developed? Respectfully.

Author: Jessica Stanley Date: Friday, April 18, 2014 10:41:45 PM EDT Subject: RE: Main Question Post Stanley

The case used for this week’s assignment was T.F. v. Fox Chapel School District. In this particular case, the family sued the school their son was attending in kindergarten stating the school failed to provide Free Appropriate Public Education (FAPE) and discriminated against them in Section 504 of the Rehabilitation Act of 1973, Title 15 of the Pennsylvania Code, and the Pennsylvania's Human Relations Act (Schwab, 2013). The plaintiffs, or parents of T.F., accused the Fox Chapel School District of ignoring their child's severe allergic needs and restrictions and claimed the school did nothing to help their child.

There were seven claims made by the child's parents: the school failed to provide accommodations to the child's life threatening allergy to tree nuts, the school failed to provide an individualized service plan, the school isolated and segregated the boy by having 
him sit alone at a lunch table, the school did not act on continued harassments claims, the school disclosed their child's information to other parents, nurse discussed confidential information, and the school retaliated by subjecting the parents to truancy hearings (Schwab, 2013).

Roddick (2014) states that in order to prevail on a claim under Section 504 of the Rehabilitation Act, the plaintiff must prove the child has a disability, the child qualified to participate in the program, and the child was denied the benefits of the services because of their disability. In addition, Roddick (2014) explains that the plaintiff must prove the school knew the federally protected right was being violated and failed to act, the child was harassed to an extreme that the child's education was altered, and the school did not take action after identifying harassment.

The court found that the school district took reasonable steps to accommodate the student's disability by meeting with the parents several times to individualize service agreements and emergency plans (Roddick, 2014). It is noted in the court documents that the parents rejected the school's plans established by the Special Education Coordinator, the Head Nurse, the Principal, the Kindergarten teacher, and the parents who previously agreed to one of the plans and later reversed their decision (Schwab, 2013). In particular, the court stated that the school is not required to grant specific accommodations requested by the parents or make modifications to a program that is used by all students (Roddick, 2014). The court also found insufficient evidence of teasing which could not support the claims of violating Section 504 and concluded the parents failed to establish the peer-to-peer harassment claims and ruled the school did not act deliberately indifferent against the child.

Additionally, the court rejected the parent's retaliation claims stating that it is required by law to file a truancy citation when a child stops attending school (Roddick, 2014). According to court documents, the parents removed T.F. from the Fox Chapel School claiming their dissatisfaction and harassment claims. This decision clarifies the interpretation of deliberate indifference standards of Section 504 of the Rehabilitation Act of 1973 (Roddick, 2014). Section 504 does not mandate schools to alter their programs. As such, the courts will need to be mindful of the balance between the rights of the student and the parents as well as the legitimate financial and administrative concerns of the school district (Roddick, 2014). This decision impacts future disability and harassment claims showcasing the importance of documentation and continued efforts to meet children's needs.

\section{References}

Roddick, K. (2014). Federal Court Rules School Did Not Violate Section 504 By Having Allergic Student Eat Lunch at a Desk in Cafeteria. School Law Bulletin. Retrieved from http://www.kingspry.com/articles/slb-129-lunch-seat-does-not-violate$\underline{\text { 504.html }}$

Schwab, A. (2013). T.F. et. al v. FOX CHAPEL AREA SCHOOL DISTRICT-Document 54. Retrieved from http://law.justia.com/cases/federal/districtcourts/pennsylvania/pawdce/2:2012cv01666/206711/54 
Author: Kiyoung Kim Date: Saturday, April 19, 2014 7:04:30 AM EDT Subject: RE: Main Question Post_Stanley

Hi. Jessica,

Thank you for the informative post. I have commented elsewhere that the courts would prefer to grant a claim about the traditional pattern of harm. A wrongful death in the Sea World of Florida from the Sheila's example may not be distinct from your case if we apply an enhanced standard as verified from the work of modern science. An animal trainer would be similar as a disabled student if the animal got wrong. A theory of developmental disability or special education would produce many truths or possible improvements in view of universal benefit of the public education, but would require a stringent command financially. The public schools must spend much more if to respond with the kind of individualized problems. Despite an elaboration to support the case of parents scientifically and educationally, the cost and benefit attitude tends not to lose eventually. The impact of court decisions would not be limited to that specific case, but also extend at the national scale and might provide a comparative modality for the foreign jurisdictions. For example, this kind of public controversies would stress the policy makers in Korea and her judiciary. It would impact not only on the agencies, but also the businesses and public entities generally. Hence it would be unwise only to blame the courts for their conservative stance. A cost saving may mean a frugality which is seen as one of Republican virtues, but new discoveries and scientific factors still push to wheel the society ahead. A neutrality and objectivity are really the critical talent and qualification as a public agent beyond the scientific desirability or ideals.

Respectfully.

The corporation petitioned for a discretionary review challenging the complaint and citation first contending that the findings of an alleged hazard to personnel deprived the animals of stimulation to prevent boredom, their handlers of opportunity to ply their craft, and the public of educational entertainment. The corporation was also contesting a lower court ruling that affirmed the OSHA findings contending that procedural improprieties in the nine-day trial violated the Due Process Clause of the Fifth Amendment to the United States Constitution. Their petition to the highest court was denied based on their inability to provide their employees with safety from recognized hazards that put them in jeopardy of death or physical harm.

Kerwin and Furlong (2011) have noted that most of the rules written by OSHA have been contested either by labor or management. In Sea World of Florida LLC v. Secretary of Labor criteria used to deny further adjudication was that the General Duty Clause of the Occupational Safety Health Act does not demand excessive levels of worker protection and is not illegal (p. 261). One important impact of this decision on rulemaking in the future is that those rules written in compliance with statutory policy emanating from the executive or constitutional branches and appropriately enforced on behalf of actually injured parties are less likely to merit judicial review beyond the level of lower courts.

Kerwin, C. M., Furlong, S.R. (2011). Rulemaking: How government agencies write law and make policy (4th ed.). Washington, DC: CQ Press. 
Author: Thomas Stone Date: Saturday, April 19, 2014 1:20:09 AM EDT Subject: Thomas Stone WK7 Initial post

\section{Application Assignment Example}

For this week's application assignment I choose to use the case of the Federal Communications Commission (FCC) and the implementation of the broadcast delay. The intention of this case was to prevent vulgar or offensive language from transmitting over the airways in both television and radio. The ruling of the FCC was challenged by some of the network stations, such as Fox, NBC, ABC and CBS. The ruling was at the court of appeals for the second circuit awaiting the appeals to initiate. However, the FCC just days before the case to be heard, requested an extension to review the previous decision records. The affiliated networks did not believe it was correct to allow the FCC an extension and believed that what the FCC was doing could be considered unconstitutional.

\section{Decision Made by Courts}

The initial decision of the courts was the FCC has established guidance as to the delays in programs and when they go out on the air. Furthermore, according to the courts, the FCC and the broadcasting delay were not unconstitutional and there for the safety of the children, who may be up watching these stations and hearing this vulgar or tasteless language and activities that are put out over the air.

\section{Impact of the Decision}

This case and many like it have a large impact on decision making process, such as when do we allow such language get broadcasted over the net and television. Some of the shows broadcasted on these affiliate channels have argued that they should have a time period when the language and sex acts may continue as they have in previous cases.

References:

Harrington, C. B., \& Carter, L. H. (2009). Administrative law and politics: Cases and comments. (4th ed.). Washington, DC: CQ Press.

Kerwin, C. M. \& Furlong, S.R., (2011). Rulemaking: How government agencies write law and make policy. Washington, DC: CQ Press.

Author: Kiyoung Kim Date: Saturday, April 19, 2014 6:22:58 AM EDT Subject: RE: Thomas Stone WK7 Initial post

Hi. Thomas,

I agree that the first amendment right is not plenary, but within the limit of public interest. The air time should be sacred in our normal sensibility. The travelers often may accompany their family or perhaps decent friends in a small space available. The children may be on board with a plain exposure of views or monitors. In that case, can you state if there was any 
claim that the prestige or business class in the airplane would be an exception? Thank you for the exciting post. 


\section{[Week 8]}

Author: Kevin Fandl Date: Wednesday, April 23, 2014 5:07:41 PM EDT Subject: RE: Discussion 1 - Week 8

That is a very good case to focus on for this week. In that situation, the President was not authorized to seize steel mills to prevent a strike. But under President Regan, 30 years later, the President was permitted to "fire" union airline workers. What was the difference, legally speaking?

\section{KJF}

Author: Kiyoung Kim Date: Friday, April 25, 2014 1:27:12 AM EDT Subject: RE: Discussion 1 - Week 8

\section{Hi. Dr. Fandl,}

Thank you for the question. Two cases share similarities in that both involve a property right or near-to vested rights about the employment status. It would be deemed rightly the rights or interests of person which should only be defined by the congressional act. The law making authority of congress would be a unique source to set forth the content, limits and exceptions of contractual freedom, torts and property right. Further on fundament, the congressional acts of such scope should never obliterate the classic basics of civil society. They should compensate for the taking, and the Contract Clause, only binding on the State though, would impede an impermissible intervention into the contracts. Hence, the Congress would have a constitutional limit on both cases. Except for the basics and exceptions, such as substantive due process, the state policy and national regulation about the property rights and freedom of contract would be autonomous in a leniency of policy making. The legitimate public authority, federal or state, may enact a new concept of property rights in response with the technical advances. A knowhow and computer software programs may enjoy the quasiproperty status in duly enacted statutes. Hence, the change of circumstances and evolution or progress on the public policy could transform the values and institutions of private sector, but still not in the contradiction of Constitution. The Executive would act within the delegated context to create the rules and implement the laws or rules. The action of Reagan administration would be based on the statute, perhaps with many avenues and interpretive possibilities, and they might exercise their discretion eventually to fire union airline workers. It should be good for the national security, public peace, market ordering and so. The consequence would be serious, but mitigating factors could support that discretion. They would be generally on the private employment so that the due process concept would not be decisive unlike the dismissal of no tenure state university professors. The theory of "employment at will" is a basic civil frame of American society other than weak social legislations. I am not sure if the union workers are public employees. Even in that case, the President would be more competent to do that action. The steel seizure case, in a different extent and quality, would touch on the core of property rights other than a weak of contractual status or entitlements. They perhaps would never directly order the firing of workers for the private businesses, but might permit as an exception of labor laws or standards. They may be largely undisputable if they fired their own workers within the Government. Respectfully. 
Author: Belinda Szerletich Date: Wednesday, April 23, 2014 10:53:04 PM EDT Subject:

RE: Discussion 1 - Week 8 Morrison v. Olson, 487 U.S. 654 (1988)

Morrison v. Olson, 487 U.S. 654 (1988)

Argued: April 26, 1988

Decided: June 29, 1988

Morrison v. Olson, 487 U.S. 654 (1988) was a case that presented questions of constitutionality of independent counsel provisions of the Ethics in Government Act of 1978. An investigation in the part of the Justice Department indicated there was some controversy between the House Judiciary Committee and the Environmental Protection Agency (EPA) regarding the limitation of producing certain documents subpoenaed earlier in the House investigation. In Morrison v. Olson (1988) reported indicated that false testimony was given in the EPA research, and the Attorney Generals; Office Independent Counsel Olsen influenced two other counsels Schmults and Dinkins by wrongfully withholding certain official documents.

In Morrison v. Olson (1988), the argument was made whether Olson's testimony mattered and violated federal law by obstructing the evidence that affected the EPA investigation. Morrison v. Olson (1988) also argued the contention of counsel to comply too a subpoena request. 1) The Appointment Clause is in effect for appointment of independent counsel in Special Divisions of Governmental Agencies. In this case, the Attorney General's Office appointed the independent counsel for this case. 2) The inferior title of an officer, Congress may appoint the inferior officers which contribute to the Head of the Department. For example, in this case the Attorney General enacted Olson as an independent counsel, not inferior officer so Congress has no authority to remove an Agency counsel. 3) Morrison $v$. Olson (1988) case gives the clarification of the Act a Governmental Division no power to review any of the independent counsel's actions or any of the Attorney General's actions in regards to counsel.

The U.S. District Court ruled that no violation had occurred in Morrison v. Olson (1988). Under the Appointment clause, special counsel in this case was limited to the duties affected by the inferior officer's part she obtained during an appointment. Justice Scalia stated that, in the article, two of the Constitution that executive powers shall be vested in the President of the United States.

Justice Scalia referenced that all parts of executive powers are in question not some parts. However, the statute in this case refers to independent counsel not inferior officer; therefore the executive powers are not valid in this case.

The overall outcome of Morrison v. Olson (1988) showed that independent counsels who are appointed by governmental agencies are given the authority under the Act to proceed without question. As in this case the failure to submit all documents requested through a subpoena.

References 
Ethics in Government Act of 1978

Morrison v. Olson, 487 U.S. 654 (1988)

Author: Kiyoung Kim Date: Friday, April 25, 2014 2:08:35 AM EDT Subject: RE: Discussion 1 - Week 8 Morrison v. Olson, 487 U.S. 654 (1988)

Hi. Belinda. I agree that the independent counsel act could be merited to provide a working arm for the congressional oversight role. While we conceive of the congressional role as indispensable and necessary, we may disagree over its exhaustive effect to paralyze the unique office of Presidency. He may still be responsible to no authority if the office execute an executive function and the Congress or judges would be less adequate to supervise in the effective way institutionally and from their professional quality or capacity. A lone dissenter in this case, Justice Scalia, later admitted that this was one of wrenching cases he ever dealt in his professional life. In my view, the independent counsel could increase a workable government and serve a congressional need for oversight. However, it would be vulnerable to partisan politics as we sensed, and worse without a due limit and proper supervision or some quorum context of competence and authority. Somebody may think that the contempt of Congress with some enlarged penalties could come as replacement, which I also share its modest function, yet to be uncontestable from the constitutional challenge. How do you consider any difference about the response of both presidents to defend their branch, "enforcement sensitive function” for Reagan and "confidentiality of high level communication” for Nixon? Respectfully.

Author: Rebecca Sampson Date: Thursday, April 24, 2014 9:50:48 PM EDT Subject: RE: Discussion 1 - Week 8

In the matter of United States v. Curtiss-Wright (299 U.S. 304, 1936), the issue of foreign policy and presidential authority is called into question. The background of this particular case centers on the South American Wars, known as the Chaco War, which occurred during the 1930s. In the course of these events, the defendant, Curtiss-Wright Export Corporation, was being charged with selling certain weapons of arms to Bolivia in violation of the Joint Resolution of 1934(chapter 365, 48 Stat. 811) which prohibited such sales. President Roosevelt acted on the provisions of the Joint Resolution and issued the embargo against such sales with the following proclamation:

'Resolved by the Senate and House of Representatives of the United States of America in Congress assembled, That if the President finds that the prohibition of the sale of arms and munitions of war in the United States to those countries now engaged in armed conflict in the Chaco may contribute to the reestablishment of peace between those countries, and if after consultation with the governments of other American Republics and with their cooperation, as well as that of such other governments as he may deem necessary, he makes proclamation to that effect, it shall be unlawful to sell, except under such limitations and exceptions as the President prescribes, any arms or munitions of war in any place in the United States to the countries now engaged in that armed conflict, or to any person, company, or association acting in the interest of either country, until otherwise ordered by the President or by Congress.” 
The violation of the embargo on the part of the defendant was seen as a direct violation of the Joint Resolution, thus the case being heard in the Supreme Court. The argument was presented by the defendants regarding the amount of authority or power that was given to the president to issue a law of such magnitude, to give him explicit powers to act almost independently on foreign affairs, to a point that it was unconstitutional.

Justice Sutherland wrote the opinion of the Court, which reflected not only the enumerated powers that were given explicitly in the Constitution, but invoked the implicit or implied powers that are necessary to carry out the appropriate actions of the federal government. In his decision, to make his point clear, Justice Sutherland writes:

"It is important to bear in mind that we are here dealing not alone with an authority vested in the President by an exertion of legislative power, but with such an authority plus the very delicate, plenary and exclusive power of the President as the sole organ of the federal government in the field of international relations -- a power which does not require as a basis for its exercise an act of Congress but which, of course, like every other governmental power, must be exercised in subordination to the applicable provisions of the Constitution.”-Justice Sutherland, United States vs. Curtiss-Wright

References

United States v. Curtiss-Wright, 299 U.S. 304 (1936). Retrieved from

http://caselaw.lp.findlaw.com/scripts/getcase.pl?navby=CASE\&amp;court=US\&vol=299\&pa ge $=304$

Author: Kiyoung Kim Date: Friday, April 25, 2014 2:50:25 AM EDT Subject: RE: Discussion 1 - Week 8

\section{Hi. Rebecca,}

Thank you for the excellent posting. You said “....regarding the amount of authority or power that was given to the president to issue a law of such magnitude, to give him explicit powers to act almost independently on foreign affairs,...” The view should be highly pertinent since the federal power generally lacks the criminal muscle, only to be permissible to increase the federal interests. It would be egregious if the extent of punishments were not to be contemplated by the Congress. Otherwise, the presidents may exercise an uncurbed ambit, perhaps not as purposeless, but in response with the war needs. In any way, the predictability or legal stability would not operate in this case, but as permissible on the ground that it is a war time in national emergency or that the proclamation solely falls within his responsibility of foreign policy making. This conflict could be resolved by staffing a written provision of national militia or emergency power of president, as in the case of South Korea and others. How do you, however, distinguish a similar context of emergencies, the environmental disaster, such as Hurricane Katrina and Tsunami and war. For example, the movie scene, Armageddon would depict a harsher predicament of society than war. Then do you believe if the presidency should be staffed with a higher level of emergent power?

Respectfully. 
Author: Jessica Stanley Date: Thursday, April 24, 2014 11:10:30 PM EDT Subject: RE: Main Question Post_Stanley

The United States v. Lopez

The case selected for this discussion is the United States v. Lopez. In March of 1992, Alfonso Lopez, Jr. who was a few weeks away from his high school graduation arrived at school with an unloaded handgun and five bullets (Scott, 1996). The child, who was confronted by law enforcement, admitted to having a weapon and was charged with firearm possession on school grounds under the Texas law (Scott, 1996). This action violated both state and federal laws Gun-Free School Zone Act of 1990 and because the Act was a federal offense, the states charges on the child were dismissed (Scott, 1996).

Lopez claimed that the Act was unconstitutional because Congress had exceeded its power to control public schools however the district court did not agree (Scott, 1996). The district court stated the Act was within Congress' power to control interstate commerce activities (Scott, 1996). Lopez then proceeded to waive his right to a trial who found him guilty and sentenced him to six months in jail and two years of supervised release (Scott, 1996). Lopez appealed and stated that Congress exceeded its powers under the Commerce Clause which resulted in the U.S. Court of Appeals in the Fifth Circuit reversing the original conviction citing the Act was an invalid act on Congress and its power (Scott, 1996). In addition, the Court of Appeals stated that neither history nor the act verified the description of interstate commerce (Scott, 1996). As a result, the Supreme Court sided with the Fifth Circuit and declined to enlarge the role of legislative control (Scott, 1996).

The Court stated that Congress' commerce power exists under three areas: interstate commerce, instrumentalities between states, and transactions of interstate commerce. Scott (1996) stated that the court analyzed the constitutionality of the Gun-Free School Zone Act of 1990 and concluded that the Act does not substantially affect interstate commerce. The government, however, openly admitted that legislative history omitted congressional findings on taking guns to school and interstate commerce which resulted in their decision. Two days after the Lopez decision, President Clinton presented Congress with the Gun-Free School Zones Amendment Act of 1995 adding that firearms be proven to affect the interstate commerce (Scott, 1996).

\section{References}

Scott, J.M. (1996). Constitutional Law-Supreme invalidates federal Gun-Free Zones Ac. University of Arkansas at Little Rock Law Journal, 18, 513.

Author: Kiyoung Kim Date: Saturday, April 26, 2014 4:18:16 AM EDT Subject: RE: Main Question Post_Stanley

Hi. Jessica,

A Great post to learn the interbranch conflict, court attitudes and the aftermath action from the government. I may suppose if the issue might include a partisan disagreement. I am curious how the major two parties perceive the carry gun issue. If hard on disagreement, we can seek a neutral and honest opinion from other parties. Perhaps the Libertarian and Constitution Parties would advocate a free carry right while the Green Party would be median 
from any extremes. How much would the independents develop their disfavor of carry gun laws from the continual mishaps in decades? I was heard from my native country that Georgia would endorse a pro-gun carriage legislation days ago. A carry gun controversy, along with the immigration issue, perhaps is the center of contest in the next presidential election. The Gun-Free School Zone Act seems to be indispensable partly because the youths would be immature, and because the school zone could be relatively a safe place given an adequate premise and on some less need for self-defense. How much do you see if the Congress and President would disagree on this issue? Whose institution would be more resilient and conservative? I may raise two points. Can you see it responsive if the possibly higher penalties from the state government could be impeded by the federal legislation merely on the basis that the federal law preempts the state laws? Respectfully.

Author: Denene Reynolds Date: Friday, April 25, 2014 6:49:18 PM EDT Subject: RE: Discussion 2 - Week 8

A Supreme Court case that received nationwide attention in 2012 was the National Federation of Independent Business v. Sebelius case. This landmark legislation allowed Obamacare to proceed based on the principle of Congress's constitutional ability to tax individuals. While the government won the case, the power of Congress was limited based on the justices ruling Congress's ability to implement the policy based on the Commerce clause.

From the minute it was proposed, Obamacare was set to be a controversial piece of legislation. Once it was passed by Congress, the challenges in the courts rolled in. These challenges of individuals, 26 states and the National Federation of Independent Business were rolled into one case and heard by the Supreme Court. The two issues the court addressed in the Obamacare case were the individual mandate (requires all individuals to have some form of health insurance or pay a penalty) and Medicaid expansion. The government based its argument for the individual mandate on two principles. The first was that the individual mandate provision was an acceptable exercise of Congress's power through the Commerce Clause granted in the Constitution. The second argument was that the individual mandate was a valid exercise of Congress's ability to tax, also granted in the Constitution. While the court agreed ruled the mandate valid based on the second argument, it found that the first argument was not valid. If the government had based the individual mandate on just the Commerce Clause, the individual mandate would have probably been overturned. Here's why:

Article I Section 8 of the Constitution states "The Congress shall have power... To regulate commerce with foreign nations, and among several states, and with Indian tribes;" (Harrington \& Carter, 2009). The government argued that all individuals will at some point in time engage in the healthcare industry. If someone does not have insurance but goes to the hospital, the cost must be covered somehow. If individuals elected not to buy health insurance, the cost would be driven up for those individuals who did. The political principle was that Obamacare need healthy individuals who rarely get sick or see the doctor to buy into the system to cover and bring down the cost for everyone else. In the ruling Justice Roberts acknowledged that the Constitution granted Congress the power to regulate commerce. However, "The power to regulate commerce presupposes the existence of commercial activity to be regulated" (National Federation of Independent Business, 2012). If an individual elects to actively engage in the commercial activity, the 
Commerce Clause does not grant Congress the authority to force them to. He went on to state:

“The individual mandate, however, does not regulate existing commercial activity. It instead compels individuals to become active in commerce by purchasing a product, on the ground that their failure to do so affects interstate commerce.

Construing the Commerce Clause to permit Congress to regulate individuals precisely because they are doing nothing would open a new and potentially vast domain to congressional authority” (National Federation of Independent Business, 2012).

Essentially, by striking down the argument of the individual mandate based on the Commerce Clause, the Supreme Court constrained any further regulation based on an individual's decision not to engage an activity.

\section{Resources:}

Harrington, C. B., \& Carter, L. H. (2009).Administrative law and politics: Cases and comments (4th ed.). Washington, DC: CQ Press.

National Federation of Independent Business, et al v. Sebelius, Secretary of Health and Human Services, et al., 132 S. Ct 2566 (2012)

Author: Kiyoung Kim Date: Saturday, April 26, 2014 5:14:00 AM EDT Subject: RE: Discussion 2 - Week 8

Hi. Denene,

Thank you for the good posting. The Commerce Clause had been one of most notorious legal grounds to expand a federal jurisdiction. This Clause also would be invoked largely to strike down the state legislations which impose an undue burden on the free flow of national commerce. Nonetheless, it should not be interpreted impermissibly to force the ruled to do sacrifice positively, but groundlessly. The case could be highlighted that the judiciary would be an important organ for both of state and federal regulators. Actually, mandating to purchase a service or product would not be the same in manner and quality that the industry should abstain from the use of dangerous chemicals or so. Given the Clause motivated to ensure the free flow of national commerce, the government argument would be less commerce-friendly, but to place a burden. It would be candid to argue that the action would be compatible with taxing. In terms of two important and traditional state functions, say, criminal and tax, how much do you think the Supreme Court will place limitations on the federal government ahead. How much do you imagine if the United States is not a state in this respect? A federalism would contribute to the intricacies and artful intelligence of government which tends to get lay people irrelevant and less straight to reach. Respectfully.

Author: Karen Davis Date: Friday, April 25, 2014 10:48:42 PM EDT Subject: RE: Discussion 2 - Week 8/Article: Yates, J. \& Whitford, A. (1998). Presidential power and the United States Supreme Court. Political Research Quarterly

There were different cases that I could have chosen to give a description on. However, the case that I chose to focus this discussion post on is, "Yates, J. \& Whitford, A. (1998). 
Presidential power and the United States Supreme Court. Political Research Quarterly,. I chose to select this case because it deals with the entity of The United States Supreme Court having the power and authority over The President Of The United States Of America. The above-mentioned case deals with asserting who has the legal power to actually in a sense tell the President of The United States of America what he or she can and cannot do. While some may believe that it is Congress-and to a certain extent it is. However, at the same time it is more so the The highest court within the country-The United States Supreme Court.

The above-mentioned states, "From the perspective of the judicial literature, they found that extralegal factors determine presidential power/success in the federal district courts.

Specifically they found that presidential prestige (approval) and judicial loyalty to appointing presidents are significant determinants of presidential success in the federal district courts." In other words, the excerpt is saying that a strong loyalty exists between the President and The Supreme Court Justices.

Within this case there are arguments presented by both sides-The President and Supreme Court Justices. For example, the above-mentioned article states, "We find that justices' decisions to support the president are conditioned upon presidents' public approval ratings and the justices' ideological inclinations." The President/executive branch does not feel however, that the Supreme Court should be concerned with the President's approval ratings so much that it makes the Court lose its objectivity.

Finally, in closing, the case I selected above was decided by basically making it clear that The United States Supreme Court in a sense is the President of The U.S. legal referee. Which therefore, means that The Supreme Court closely watches every move that The President makes.

\section{Hi. Karen,}

Thank you for the informative post. I agree on your metaphor to ascribe the USSC as the President of the US legal referee. Nonetheless I respectfully disagree if the system of judicial review is one of merited institution to serve a democratic rule. One peer institution may work for a comparative view. The French system would be proper to state if judicial intervention as a priori functions to legitimate the state action both from the legislature and executive. They would undertake to review a constitutionality of congressional and presidential acts before they go into effect. Hence their opinion would be general and abstract so that the review could be trivialized to merely put a ribbon on the attempted action. One tenet may be that the constitutional issues are a basic structural one of state or nation which is sacred and perhaps desirable to be insulated from the normal adversary frame involving an individual citizen. In my knowledge, no follow up could be possible to dispute a legislation by the individual citizens in this case, which is anti-democratic and pro-bureaucracy. A private sector would be, in the least, an important component of community, albeit no sovereign identity, which compels the need and merits of US mode judicial review. In this background, Korean people had to be jubilant to realize the constitutional complaint in 1987 Constitution, which safeguarded their human rights procedurally. It was distinct that Korean people entertain two separate authorities of judiciary, but its general role would share the US ideals. Anyway, it would be deplorable that the US justices have fared to respond within the bureaucratic attributes. Respectfully. 


\section{[Week 9]}

Author: Tiffany Austin Date: Wednesday, April 30, 2014 4:42:03 PM EDT Subject: RE: Discussion - Week 9

\section{Main Discussion Post:}

The policy issue I chose for this discussion is public health. Public health is a system of official government public health agencies as well as public and private sector agencies that perform acts which impact the health of the public (United States Department of Health \& Human Services).

Federalism is the division of governmental power between state and federal governments. However, federal laws would get precedent over state and local laws. Should state and local laws conflict with federal laws, the federal law will get precedent (Sikora, 2002).

An example of how federalism can contribute to conflict between federal and state laws is the health care law. The law has a provision that allows states the option to expand thier medicaid programs. The state of Georgia has chosen not to expand its medicaid program. However, its citizens are still required to be covered under some basic health care program or face a tax penalty. An effect that it has had on some citizens of the state is that some don't qualify for the state's Medicaid program but are still unable to afford the mandated insurance coverage leaving them in a tight situation. It also demonstrates how state and federal laws can conflict and how the federal law will still gain precedence regardless of the state's laws.

\section{References:}

Sikora, V. A. (2002). Federalism: How the principle works on state and local levels. Journal of Environmental Health, 65(3), 44-47.

United States Department of Health \& Human Services. (n. d.). What is the public health system? Retrieved from http://www.hhs.gov/ash/initiatives/quality/system/ on April 29, 2014.

Obamacare Facts. (n. d.). ObamaCare medicaid expansion. Retrieved from

http://obamacarefacts.com/obamacares-medicaid-expansion.php on April 30, 2014.

Obamacare Facts. (n. d.). ObamaCare individual mandate. Retrieved from http://obamacareindividual-mandate.php on April 30, 2014.

Author: Kiyoung Kim Date: Saturday, May 3, 2014 8:58:00 AM EDT Subject: RE: Discussion - Week 9

Hi. Tiffany,

Good post. The public health is an important policy area, and the federal law will get a stronger extent of precedent than other areas since the general welfare is constitutionally explicit to confer on the federal power. It is also a crucial area that the uniformity and national standard need to be administered. If the health care law allows an option for the 
states, it suggests that the situation would be highly difficult so as not to command a uniform response from the states. An expansion of the Medicaid program would require a burden on the state and may provoke a fairness issue among the interested class. What do you think most contributive to the decision of state not to expand the Medicaid program?

Respectfully.

Author: Divine Ayivor Date: Thursday, May 1, 2014 1:18:22 PM EDT Subject: RE: Main Post: Discussion - Week 9

The policy area chosen for this assignment is Immigration. Immigration is a term used to describe the process of a citizen of one country relocating to another, for several reasons, work, education, business or health reasons and seeking residence in another country, legally or illegally. "Federalism is the horizontal division of governmental power between the federal government and state government". (Sikora, 2002. p. 1).

Article VI of the U.S. Constitution has a supremacy clause which makes federal laws superior to state and local laws. So that in any conflict between the states or local government, the federal law must be preempted. In the case of Arizona et al., $v$ United States, the state of Arizona felt that the immigration policies of the Federal government are weak and rather contributed to the over representation of illegal aliens in their state. The state of Arizona passed a Senate Bill 1070, which contained stringent provisions to crack down on illegal immigration, including, harboring, transporting, hiring illegal aliens without federal involvement. But 8, U.S.C. 1357 (9)(1) authorizes the Secretary to enter into a written agreement with the States specifying which state subdivision ... may carry out detaining aliens in the United States.) Arizona disregarded the Constitutional authority of the Federal government. The federal government filed a law suit against the state of Arizona.

The State of Arizona's vision of immigration enforcement relied on attrition and the President preferred legalization strategy (Rodriguez, 2014). Federalism contributed to the resolution of this conflict which was a Democratic Party and a Republican issue. The federal laws supercede state and local laws and Arizona must follow federal regulations and not be allowed to carry out its own politically motivated agenda.

Reference:

Rodriquez, C.M. (2014). Negotiating Conflict Through Federalism Institutional and Popular Perspectives. Yale Law Journal, 123 (2094).

Author: Kiyoung Kim Date: Saturday, May 3, 2014 9:45:36 AM EDT Subject: RE: Main Post: Discussion - Week 9

Hi. Divine,

I agree that the Arizona et al v. US is a fine example for the federalism and preemption doctrine. A remarked increase of illegal aliens would certainly be a vexing challenge to raise the state expense to respond with many traumas and social cure for the sound community. It may double the expenditure to subsidize education, public health, housing, and social benefit 
for the illegal immigrants. The immigration issue, nevertheless, would traditionally be deemed to fall within the responsibility of federal government. The policy area would not be blithely clear since the police power intrinsically vests within the state province. How much do you agree if the employers would be penalized as a petit criminal and the federal government has a legalization strategy in the tight schedule of enforcement? How do you think that the presumption against preemption should be granted if the challenged function of state government is classed as an exercise of the traditionally inherent state power?

Respectfully.

Author: Divine Ayivor Date: Saturday, May 3, 2014 10:24:21 PM EDT Subject: RE: Main Post: Discussion - Week 9

Hi Kim,

Hiring an illegal alien is against federal, state and local laws for tax purposes. There have to be a social security number and legitimate visa authorizing work eligibilty. Over looking such requirements undermines the local, state and federal establishment and employers who disregard the law must be penalized. Federal supremacy clause is in place to subordinate any traditional inherent state power creating some form of uniformity on the general legal landscape of United States. So that every law coming down from Congress has input from representatives from the union at large. No one state has any power inherent that overules the federal laws. Thanks for reading my post.

Author: Roberta Richardson Date: Thursday, May 1, 2014 11:16:35 AM EDT Subject: Main Post: Discussion - Week 9

Federalism is a system that splits responsibilities among the federal, state, and local governments. It prevents a system of dictatorship although it is sometimes difficult to tell. The ongoing power struggles for power between the various branches of the federal government and subsequently the local authorities creates a system of rebellion in some instances.

As an example, the federal government's regulation on Drugs has created a snow storm of controversy. Federal law prohibits the manufacturing, distribution, possession, and sell of marijuana in the United States however at least 18 states have passed laws that contradicts the federal law. Those respective states as well as Washington D.C. have taken measures to decriminalize marijuana.

The federal government cannot generally mandate that states adopt specific laws that align with those adopted by the federal government based on the $10^{\text {th }}$ amendment to the constitution which provides (vague) protection from this type of action. "Even if the federal government is prohibited from mandating that the states adopt laws supportive of federal policy, the constitutional doctrine of preemption generally prevents states from enacting laws that are inconsistent with federal law. Under the Supremacy Clause, state laws that conflict with federal law are generally preempted and therefore void” (Garvey)

An individual could comply with state law regarding the use of medical marijuana never the less they are in violation of federal law. "Enacted in 1970, the CSA establishes a 
statutory framework through which the federal government regulates the lawful production, possession, and distribution of controlled substances. Marijuana is currently categorized as a Schedule I controlled substance, and is therefore subject to the most severe restrictions contained within the CSA. (Garvey)

According to Garvey, The U.S. Supreme Court considered the reach of Congress's Commerce Clause authority and the constitutionality of the CSA in Gonzales v. Raich however, as previously noted, the principles of federalism prevent the federal government from mandating that the states support or participate in enforcing the federal law. Tenth Amendment likely prevents such an intrusion into state sovereignty.

References:

Garvey, T., Medical Marijuana: The Supremacy Clause, Federalism, and the Interplay Between

State and Federal Laws, November 9, 2012, retrieved from, http://www.fas.org/sgp/crs/misc/R42398.pdf

Author: Kiyoung Kim Date: Saturday, May 3, 2014 9:22:30 AM EDT Subject: RE: Main Post: Discussion - Week 9

Hi. Roberta,

Thank you for the insightful post. I agree that the federalism can contribute to prevent a system of dictatorship. It would increase a state or local democracy since the state would be reserved with the power comprehensively unless the federal constitution otherwise specifies. It would be paired with the provision that the Congress would guarantee a Republican form of government for the respective states. A tyranny is the worst of many perceived dangers in the modern democracy. Federalism certainly has an attribute to check an arbitrary power which is seen as in bicameralism and separation of powers principle. Beyond the power distribution, it also implicates the theme of effective public administration as you illustrated a marijuana case. Then the wisdom may gather to best address the American public. As you said, there is no obligation for the respective states to enact a supportive measure. How much do you consider the 18 states would provoke a conflict with the federal law? Why did the federal law not provide a criminal penalty for the prohibited activities? If it did, could the penalty be enforced within the 18 states since the federal law preempts? Respectfully. 
[Week 10]

Author: Nicole Crawford Date: Tuesday, May 6, 2014 6:10:08 PM EDT Subject: RE: Discussion - Week 10

\section{Politics, Judge Selection, and Judicial Outcomes}

\section{A brief explanation of how politics might influence the selection process of federal judges. Then explain how federal judges' political ideologies might influence judicial outcomes. Be specific and use examples to illustrate your explanation.}

Even though federal appointed judges are supposed to be apolitical and are expected to remain politically neutral while on the bench, it is anticipated that their political views at times seeps into the decisions they make while in the black robe. The President of the United States has the responsibility of appointing federal judges to the Supreme Court and their selection could leave a lasting legacy for that president depending on who is appointed (pg. 248). It is inevitable, politics will always play a role in the selection of a federal judge because we entrust in them the ability and the ultimate power to declare laws constitutional or unconstitutional the method in which they are chosen is dripping with politics. For example, President Obama appointed the most recent Supreme Court judges Sonia Maria Sotomayor and Elena Kagan, both are women who were not trust fund babies, both are women who put themselves through college/graduate school, both are women were justice fighters in their childhood and it continued into adulthood. These similarities in some cases mirror the president, for instance even though Sonia Maria Sotomayor had both her parents she was closest to her grandmother, sound familiar? It is in the best interest of the president to appoint a federal judge or Supreme Court judge that will mirror his/her upbringing and their ideals; their politics. A judge that has been wealthy since coming out of the womb could never understand how a constituent family of five could go hungry, without clothes, or healthcare. The politics of selecting a federal judge is mostly in my opinion geared around ensuring this life appointment will benefit those who voted for the President who appointed them to the bench usually those are the people who will get their best bang out of the selection as it pertains to human rights. For instance, just recently DOMA (Defense of Marriage Act) was deemed unconstitutional by SCOTUS; do you think that it would have been deemed this if all the judges were Republicans or all not possess similar thinking processes of our President? On June 26, 2013 the decision of 5-4 found that Section 3 of DOMA was deemed unconstitutional; the judges that voted for this was Justice Kennedy, Justice Ginsburg, Justice Breyer, Justice Sotomayor, and Justice Kagan (law.cornell.edu, 2014). This is a prime example of politics at work, without President Obama's appointment of Justice Sotomayor and Justice Kagan this vote could have went the other way.

\section{References}

http://www.law.cornell.edu/supremecourt/text/12-307

Kerwin, C. M., Furlong, S.R., (2011). Rulemaking: How government agencies write law and make policy (4th ed.). Washington, DC: CQ Press. 
Author: Kiyoung Kim Date: Saturday, May 10, 2014 7:17:42 AM EDT Subject: RE:

Discussion - Week 10

\author{
Hi. Nicole,
}

Thank you for the informative post. The equal right to marriage perhaps seems more serious in the US. As a Korean native, I suppose that oriental virtues would seem well embedded only but with few exceptional cases. The issue likely exposes an interesting controversy between the conservatives and progressives. A heterogeneity in marriage would generally be divine and elementary with the nature. It also comes in comport with, and is necessitated to ensure the economic and social reproduction process. A decline of demography and working age people are not nugatory to bring the need of public intervention. A gay or lesbian enclave perhaps speaks for the advanced status of our community that a personal freedom would be enhanced that much. Nevertheless, I fear if the DOMA might intrude a domain of human dignity who chose a same sex marriage. Hence the controversy would never go easy as simple as the federal purpose sweeps all other interests as irrelevant, typically if concerned with the privacy right of these people. A slim majority in the Supreme Court demonstrates that the political ideologies of justice would mean and make it an importance of issue on the community. Two wings of political ideologies, as often framed, might not share any dogmatic consistence with varying issues. Besides the political ideologies, do you agree if the Supreme Court would surmise and even favor the autonomy of state regulation on this issue and diversity or plurality of American society? I suppose that the conservatives often believe that a respective state, rather than the federal government, is an essential ingredient to flourish a nation. How much can we label the new judges appointed by the President as conservative anyhow? Respectfully.

Author: Jessica Stanley Date: Thursday, May 8, 2014 9:38:25 PM EDT Subject: RE: Main Question Post_Stanley

Federal judges are important figures in the federal government system. Their services last for life while their decisions are engraved in national history. Politics play an interesting role in the selection process of federal judges. Impressive resumes and years of experience are only a few credentials judges must have to be nominated with some political underlying intent. In addition, judges are subject to background checks, article and speech reviews, candidate faithfulness with party, and alignment with current presidential public policy positions (Congressional Digest, 2005).

Congressional Digest (2005) states that Presidential appointees select high court officials that can set the tone for their administration. Federal judges are highly selected based on their expertise in the field and can support a President's administration and improve their image. For example, in 1981, President Reagan had a reputation of not being supportive of the women's movement. As a result, he was the first to name a woman into the High Court system to improve his image and reputation with the public.

Kerwin and Furlong (2011) mention that the judicial system has a varied background, full of judicial philosophies which provide an eclectic and knowledgeable base in the decision making process. Also, the varied background and expertise are critical for accountability and a strong support in the interpretation of the Constitution. As nominated judges are 
subject to intense screening of their personal, professional, and political life, they can also be selected based on the conformed idea set by the President (Congressional Digest, 2005). In addition, the judicial nominees can also benefit by being from the President's home state (Congressional Digest, 2005).

On the other hand, Presidential administration may select judges in an effort to reshape the Court. During the Clinton Administration, he appointed 129 judges, women and minority, and was highly praised for the diverse and quality of his actions (Labaton, 1994). While Bush and the Reagan Administration changed the courts by appointing those of conservative ideology, the Clinton Administration avoided making the same choices as previous Presidents as a strategic political move (Labaton, 1994).

\section{References}

Congressional Digest. (2005). Federal judge selection. Congressional Digest, 84 (5), 140-160.

Kerwin, C.M., Furlong, S.R., (2011). Rulemaking: How government agencies write law and make policy $\left(4^{\text {th }}\right.$ ed.). Washington, DC: CQ Press.

Labaton, S. (1994). President's Judicial Appointments: Diverse but Well in the Mainstream. The New York Times. Retrieved from http://www.nytimes.com/1994/10/17/us/president-s-judicial-appointments-diversebut-well-in-the-mainstream.html

Author: Kiyoung Kim Date: Saturday, May 10, 2014 8:04:52 AM EDT Subject: RE: Main Question Post_Stanley

Hi Jessica,

I agree that a diversity in the composition of federal courts is important. In Korea, the public had expected that a most important virtue would lie in the impartial and independent judiciary. They perceived that the Congress and President would only be political besides the judiciary. The transformation toward an informative society and development of e-technologies on easy public access and sharing, we began to discuss the political ideologies of Supreme Court Justices. We still see it no better that the justices are political, but the current status issue surely necessitates the constant watch of appointments to make them balanced between the conservatives and progressives. Respectfully.

Author: Sheila Waters Date: Friday, May 9, 2014 12:35:14 AM EDT Subject: RE: Main Discussion Post - Week 10

Politics might influence the selection process of federal judges when the president selects an appointee that shares his or her political ideologies. To that end during a background check of a possible candidate Justice Department personnel have at times interviewed local party leaders in the candidates' state to determine that he or she adheres to party standards as well as the President's important policy positions (Congressional Digest, 2005). Presidents and the public regard Supreme Court appointments as more important and politically significant than those made to the lower courts. 
Author: Kiyoung Kim Date: Saturday, May 10, 2014 7:51:20 AM EDT Subject: RE: Main Discussion Post - Week 10

Hi. Shelia,

Thank you for the excellent post. I agree that the autonomy of respective institution would make it better in some cases than a science or progressive activism. A school culture and institution seem typically problematic across the jurisdictions. Bullying in the school, violence against the teachers and crimes also are not rare in South Korea. It depraves a pride and energy of school teachers who may quit earlier and turn to become dispassionate and irresponsible so as to let it go as is. Hence I believe that the school administration needs to refurbish their mission and spirit to recover. I also agree that the double standard in a constitutional scrutiny of human rights would not entirely be false. The school teachers, however, have to make themselves more scientific and well prepared. For example, they may encode a self regulation which would be effective and well organized as well as youthsadaptive humanly. As we study the public policy, how do you think between the organizational or member elements and the science or system-building stance, as perhaps progressive? Respectfully.

Even though presidents have few opportunities to make appointments to the high court, when the opportunity does arise, it allows them to "make a political statement and even to set the tone of their administration” (Congressional Digest, 2005). President Franklin D. Roosevelt made the greatest number of appointments to the high court. He appointed nine justices in his 12-year administration before presidential term limits became the law. And even though he appointed Republican Harlan Fiske Stone to Chief Justice as a gesture of national unity anticipating U.S. entry into WWII, most of the appointments he made to the high court were likely Democrats, sympathetic to the president's liberal ideologies.

Federal judges' political ideologies might influence judicial outcomes by ruling in favor of a position that they know the president or his administration prefers, as evidenced by findings from research on federal judges' behavior that seem to suggest a considerable link between political party ties and judicial outcomes (Torres, 2007). For example, President Reagan asked the U.S. Justice Department to represent the State in the case New Jersey v.

T.L.O. The Justice Department then urged the Supreme Court to give school administrators more power to search students at school, putting into question their Fourth Amendment rights. Then, five justices who had been nominated by Republican presidents ruled in favor of giving greater latitude to the school administrators influenced by claims by the Justice Department and the president that disorder and crime in the schools had reached an all time high (Torres, 2007, p. 258).

Federal Judge Selection. (2005). Congressional Digest, 84(5), 140-160.

Torres Jr., M. S., \& Stefkovich, J. (2007). Students' fourth amendment rights and the federal judgeship: examining the link between political appointments and case outcomes. Brigham Young University Education \& Law Journal, (2), 257-280.

Author: Sheila Waters Date: Saturday, May 10, 2014 10:26:03 AM EDT Subject: RE: Main Discussion Post - Week 10 
Hi Kiyoung,

Thanks for reading my post. As to your question, I do not think jeopardizing constitutional mandates were warranted in this case. Unfortunately, the conservative agenda looks for easy cut-and-dried solutions to complex problems like violence in the schools. It is hostile to public education in general and beyond the capacity to problem-solve over the economic basis for deteriorating values in certain segments of society.

Thanks again 


\section{[Week 11]}

Author: Thomas Stone Date: Wednesday, May 14, 2014 11:29:49 PM EDT Subject: WK11 Disc Thomas Stone Initial post.

One of the essential functions of the media is to analyze the government, to include; federal, state and local affairs. To put it another way, the news media could be considered the ombudsman for the public to verify the government is held liable for their actions. However, according to Love (2009) the methodical directive of the news media worldwide is lessening the aptitude of people to expressively contribute in laws, rules or policies (Pg. 1).

The news media plays a large role on the effects of laws and public policies, keeping the public informed on any breaking story. According to Patterson (1998) the media has the influence, to guide public outlook and consideration, which is often times fought with the media's financial desires. "The media's role is to keep the public informed, keep an eye out for wrongdoing by political leaders, and help individuals stay current on affairs" (Patterson, 1998). In addition, the media has the responsibility and power to lead political agenda, organize discussions, and inform citizens on the value that is at stake by current political policy.

In my opinion, I believe the media is sometimes to blame for the media coverage certain crimes or the exposure of those crimes. In events involving school shootings going back to the Columbine high school shooting to the more recent event at Sandy Hook elementary school. I'm not saying the media is at fault for these incidents, but the exposure they receive and what is reported can be contradicting.

All the news channels are set to report on incidents like this, but rarely do they have all the facts prior to announcing the breaking news. I recently learned something involving the Columbine shootings, I was not aware of. I received training through the Department of Homeland Security and during that training I was informed that the two shooters intentions were to have mass chaos, and blow up a large portion of the school, but when their homemade pipe bombs did not detonate, they were forced to follow through with their plan and commit suicide. Although, it's not always the media's fault concerning the information given to the public, but I believe they rush to get the news out first and not receiving all pertinent information.

References:

Love, A., (2009). Media influence on public policy. Retrieved from: http://www.studymode.com/essays/Media-Influence-On-Public-Policy-200252.html Patterson, T. E. (1998). Time and News: The Media's Limitations as an Instrument of Democracy International Political Science Review January 1998 19: 55-67. 
Author: Kiyoung Kim Date: Thursday, May 15, 2014 8:12:46 PM EDT Subject: RE: WK11 Disc Thomas Stone Initial post.

\section{Hi. Thomas,}

Thank you for the informative posting. Your point about a methodical directive of media is quite true that it is one of critical flaws to abridge with the democratic governance. The freedom of press is most primate to practice a democracy. The present quality of media, nonetheless, may be thought arrogant in some aspect if its impact and operation looms as essential and respectful. They may be pressing the government in some cases who would be one collaborator to produce a public good. They, in some cases, over-seize the source of news report and audience to get the interaction autonomous in their direction. How do you consider if the right to dissent and work ethics need to be seriously revisited? Respectfully.

Author: Shari Tewa Date: Tuesday, May 13, 2014 8:51:00 PM EDT Subject: Shari Tewa main question post

It is no secret how media affects everything in our society today, just as it did in years gone by. We remember too well the effect of news coverage on the protests against the war in Vietnam and its role in bringing the war to a conclusion. Although studies show that young Americans not ingesting news content from any source has gone from 14 to $37 \%$ in the past eight years (Forgette, Morris, 2006), the media still wields very heavy influence on politics and law. This is true especially when the news is sensationalized and has a "high entertainment value." (Forgette, Morris, 2006) Cable news, well aware of this trend, caters to this audience and many talk shows and news hours produce graphically appetizing programs to capture those viewing audiences with use of scrolls, lower thirds, screen-in-screen displays, so that viewers may channel surf without losing track of the current program they began watching.

With formal research concluded, the verdict comes in with an astounding yes to the question of media influence on policy makers view the public's interest in the issue of the day, although the levels may vary between groups of "governmental elites and interest group elites”. (Cook, Tyler, Goetz, Gordon, Protess, Leff, Molotch, 1983) A relationship between media and politician has emerged as being pivotal in framing debates on issues. As a result of one instance of this relationship, recommendations were made by the Senate Permanent Investigations Subcommittee to introduce competitive bidding for contracts with not-forprofit Home Health Aide Programs and a re-vamping of the audit system in place then. (Cook, et al., 1983) The “active collaboration between journalists and policy makers” took the lion's share of the credit in creation of that policy.

There is also media influence of a different sort that influences public policy as in the case of the "burns your video nasty' campaign started by the Sun Newspaper after "Child's Play 3' was associated with a murder. The furor created by the media over the issue of violent movies and their influence on criminal minds led to the passage of the Criminal Justice Act of 1994 (Part VII s.90 Criminal Justice act 1994) which "extended criminality established in the Video Recordings Act 1984 to cover the supply of unsuitable material to minors." (Nagra, 2010)

References: 
Nagra, D, 2010. Moral Panics: How Media Influences the Legislature. Coventry Journalism Review. Retrieved from: http://cjr2010.wordpress.com

Author: Kiyoung Kim Date: Thursday, May 15, 2014 8:00:32 PM EDT Subject: RE: Shari Tewa main question post

Hi. Shari,

Thank you for the good posting. I agree that the media generally makes a wider impact on the law and public policy. That is true indeed that the media coverage is not limited except for specialized ones. The influence of media typically has been salient in agenda setting, and the initial attraction of public and policy makers. Its sensationalism can be viewed in a divergent prism, but play positively, in some dimension, to reach the core of issues and competing values. You mentioned a past war of Vietnam, and the war situation often creates a national dissidence. In this case, the media's role would be tremendous. Hence we awarded, for example, the kind of Pulitzer Prize, on one hand, and controlled a publication, on the other. Respectfully.

Author: Rebecca Sampson Date: Thursday, May 15, 2014 4:46:28 PM EDT Subject: RE: Discussion - Week 11

Week 10 Discussion

Just yesterday on MSNBC, I heard the following from Chris Matthews: "If you tell someone not to think about a blue elephant, chances are they will be thinking about a blue elephant." He was referring, most specifically, to Karl Rove's comments on Hillary Clinton's suspected "brain injury" she obtained after her fall. However, this comment more informally refers to the tactics that are well played out among politicians and their aids who assist in their campaigns: once something has been stated, its difficult to turn away from it, even if it is absurd or untrue.

And the forum for this, of course, is the media. With the 24-hour news cycle, the need to have the most current information and accompanied with the proper tools to acquire it (i.e. television, smart phones, Facebook, Twitter, the list continues) has created quite an intensity of information gathering and sharing. Almost to the point of throwing out information without proper verification, just to get people to be thinking about it, and the possibilities of that something being true. These actions mostly pertains to political motives, but since our politicians are responsible for deciding on what laws are passed, this makes a monumental difference in terms of public policy on whom is placed in those positions of power and is capable of pushing their agenda. The people place leaders into office through voting, so this is where I believe the media is most influential. The 24-hour news cycle allows commentators to hammer away at issues that may or may not be relevant. Moreover, if the masses are unwilling or unable to educate themselves on the topics, they are prone to believe whatever information has been presented by their primary source of information.

Author: Kiyoung Kim Date: Thursday, May 15, 2014 8:28:41 PM EDT Subject: RE: Discussion - Week 11 


\section{Hi. Rebecca,}

Thank you for the insightful posting. I agree that the most important problem in the media' role would be an unfiltered reporting to create a bias or misdirection of public opinion. I generally agree that the broadcasting does serve better when it is framed as private organization. Nonetheless, Korean public generally favor KBS, which is a kind of government subsidiary. It is thought more reliable and decent to obtain a primary source of information. The freedom of press and individual right to know or be informed seems a difficult issue provided if the media is massively a commercial-driven and unethical. An adequate shaping of media's liability also poses a difficult constitutional challenge. How much do you agree if the media is treated same as individual in the tort liability schematization?

Respectfully.

Author: Rebecca Sampson Date: Sunday, May 18, 2014 12:40:49 AM EDT Subject: RE: Discussion - Week 11

\section{Hello Kiyoung,}

Thanks for the question! I believe that the media outlets owe it to the public to report information that is true and verified and if not, formal procedures should take place to fine that organization. Hefty fines on wonrgful reporting is probably the only way to clean up the unfiltered reporting that we see taking over many networks on televisions today.

Thanks,

Rebecca 


\section{[Week 12]}

Author: Divine Ayivor Date: Thursday, May 22, 2014 8:35:13 PM EDT Subject: RE: Discussion - Week 12

\section{Global Issues:}

The global issue chosen for this assignment is capital punishment by which criminals and other deserving violators are put to death. Killing sometimes innocent people and criminals has always been; ancient Jews killed by stoning, the Romans killed by hanging on the cross, Jim Crow killed by lynching, and now is by lethal injection or the electric chair. Europe abolished the death penalty, some U.S. states has also abolished the death penalty, China executes over 3000 individuals annually and the reasoning for this disparities are deeply rooted in the traditions, religious beliefs and political institutions and policies of the various nations (Greenberg \& West, 2008).

According to (Kendall \& Siracusa, 2014), through the concerted efforts of international organizations like Amnesty International and Human Rights groups, the U.S. may eventually abolish capital punishment altogether. The invocation of the Vienna Convention has stayed executions in the United States significantly. Texas, recently violated the Vienna Convention, ignored the Obama Administration and International law and executed a Mexican, murderer and rapist sentenced to death in 1994. Texas did not inform Mr. Garcia about his rights, according to the Vienna Convention, to contact the Mexican consulate to get legal aid. Although the Vienna Convention was signed by 171 countries, Texas violated it. The U.S. is being isolated by the international community because of its capital punishment policies (Allan, 2011).

Mexico sometimes made the U.S. forgo an execution in extradiction negotiations of Mexican criminals wanted in the United States. Thus other countries and international organizations influence the U.S. policies.

References:

Allan, N. (2011). In Texas, a Death Penalty Showdown with International Law. Retrieved from www.theatlantic.com

Greenberg, D.F., \& West, V. (2008). Siting the death penalty internationally. Law \& Social Inquiry. Vol 33(2), pp. 295-343. Retrieved from www.scholargoogle.org

Kendall, W., \& Siracusa, J.M. (2014). The Death Penalty and the U.S. Diplomacy: How Foreign Nations and International Organizations Influence U.S. Policy. Retrieved from www.clcbooks.rutgers.edu

Author: Kiyoung Kim Date: Saturday, May 24, 2014 4:14:42 AM EDT Subject: RE: Discussion - Week 12

Hi, Divine. 
Thank you for the informative post. The issue of death penalty has long been contended from the concerned intellectuals and activists. It also seems to be entwined with the kind of symbolism and science. The activists oftentimes would be very knowledgeable and analytical, who argue on the probability of wrong finding, no service to the national criminal policy goal and its quality against the system and civility. On the other, some group countered that the meta-ethics and infanticide may be tangled to divulge the need of death penalty. Institutionally, the issue requires deliberating what ways are most plausible in view of Constitution and international obligations of US administration. The criminal jurisdiction falls within the essential state function which could not be surrendered generally. That would perhaps be one reason that the US still is reluctant to join the treaty of international criminal tribunals. I wonder why the international community has not yet formulated a convention of such kind, say, abolition of death penalty. I may state if the death penalty has a symbolic implication, about the personality and essentialism of traditional state function, which is beyond the science and international demand. We may get a lesson as a policy maker in two points. The national movement toward a uniform penal code needs to be reevaluated about its ambit and limits. Nevertheless, the issue would not be the same as UCC, since the latter is a commercial matter. The model penal code may work to serve to learn, appreciate and enact. The policy makers of national diplomacy, as in the deals of Bush administration with the Mexican death row inmates and Vienna Convention protocol, need to collaborate and defend the national institutions and system, i.e., federalism, the status and prestige of Supreme Court, as well as comity with the international Court of Justice. How much do you agree if we can be let with a new landscape of international relations if global jurisdictions agree to abolish the death penalty? Hypothesize if we now have a world congress. Does it support an abolition of death penalty? Do you think if the death penalty is merely a product of symbolism to indicate what a state power has been and is being? Respectfully.

Author: Sheila Waters Date: Friday, May 23, 2014 8:20:34 PM EDT Subject: RE: Main Discussion Post - Week 12

The global issue I have selected is how legalization of marijuana in the United States might impact and be impacted by international law. Global rules and standards often impact what individual countries do via the actions of their own politicians (Cortell and Davis, 1996). Additionally, treaties trump legislation because they are the highest level of regulation (Laureate, 2009). This is causing a dilemma for the federal government around the issue of legalization of marijuana. Although the Obama Administration had initially taken a neutral stance declaring a policy of non-enforcement of medical marijuana dispensaries operating in compliance with state laws and the President himself stated that he would not use Justice Department resources to "circumvent state laws on this issue" (NYC Bar Association, 2012) many observers are now confused about the recent reversal of the government's policy.

In the meantime, other countries are beginning to relax their marijuana laws and their leaders are speaking out in increasing numbers saying it is time to think about legalization. What might account for the Administration's hesitancy is a handful of international drug treaties such as The 1961 Single Convention, which strictly limits the use and possession of opiates, cannabis, and cocaine to medical and research purposes. Two others are the 1971 Convention on Psychotropic Substances and The 1988 United Nations Convention Against Illicit Traffic in Narcotic Drugs and Psychotropic Substances (NYC Bar Association, 2012). 
The 1971 Convention was enacted in response to the explosion of drug use in the 1960s adding synthetic, hallucinogenic (especially LSD) and commonly abused prescription drugs to the list of controlled substances. The 1988 Convention was created to require for the first time that member countries criminalize the cultivation, purchase, or possession of these substances for personal use even though it did not specify how people were to be punished and permitted prudent discretion for how countries implemented penalties to violators. The treaties require that each country enact their own laws for executing them (NYC Bar Association, 2012).

This situation could have far-reaching implications because these three treaties are legally binding according to the 1969 Vienna Convention of Law and Treaties. They constitute international law stipulating that countries must not neglect their obligation to abide by the conventions by enacting any conflicting laws. It could mean that any of the states that have recently legalized marijuana, especially those doing so to facilitate recreational use could be in violation of international law.

Cortell, A. P., \& Davis Jr., J. W. (1996). How do international institutions matter? The domestic impact of international rules and norms. International Studies Quarterly, 40(4), 451.

Laureate Education, Inc. (Executive Producer). (2009). Fundamentals of law and public policy: Global perspectives. Baltimore: Author.

New York City Bar Association, Committee on Drugs and the Law, Special Subcommittee on International Drug Law and Policy, (2012). The international drug control treaties: how important are they to U.S. drug reform? Retrieved May 22, 2014 from http://www2.nycbar.org/pdf/report/uploads/3_20072283-International Drug ControlTreaties.pdf

Author: Kiyoung Kim Date: Saturday, May 24, 2014 5:39:29 AM EDT Subject: RE: Main Discussion Post - Week 12

Hi, Shelia.

Thank you for the useful posting. You stated, “......any of the states that have recently legalized marijuana, especially those doing so to facilitate recreational use could be in violation of international law." I suppose that legalization of marijuana involves a scope of variables in terms of public policy. We, Koreans, now manage a system of national monopoly and partial privatization about the tobacco industry. The law here considers it one class of contraband that a possession, sales, purchase in the commercial purpose as well as recreational use are to be illegal. Perhaps its ill consequence on the public health would be secondary if the market became to be legalized. The issue seems to relate comprehensively with the businesses, juvenile crime, public standard of morality, and public health. In Korea, the impression is not sound while entertainers occasionally misuse the substance in the end of sexual purpose and the gangsters would exploit to earn an impermissible rate of profits. As you stated, the treaty is a federal law that both the federal and state governments are bound to obey. Nevertheless, the Courts developed a "presumption doctrine" that the treaty itself could not be a binding norm in the domestic jurisdiction. This dualism between the international treaties and domestic laws often are advocated by the US and British jurisprudence. The 
theory and practice, then, has a subtlety in difference from the continental laws of Europe. In this respect, I consider that there would be ample ways to contend against the international responsibility. How do you see it acceptable that the state government, instead of federal government, is a legal actor to be litigated in view of international public laws? Respectfully

Author: Sheila Waters Date: Sunday, May 25, 2014 12:33:36 AM EDT Subject: RE: Main Discussion Post - Week 12 Answer to Kiyoung

Hi Kiyoung

Thank you for reading my post Kiyoung. I think if treaties are the highest of legislation, they must be respected. They either do or do not trump local legislation. It is confusing for there to be standards where sometimes treaties are most powerful, and other times they are not. I also wonder who initiated those treaties. 